\title{
THE SIGNIFICANCE OF THE RULE OF LAW AND ITS IMPLICATIONS FOR THE EUROPEAN UNION AND THE UNITED STATES
}

\author{
Ricardo Gosalbo-Bono*
}

Table of Contents

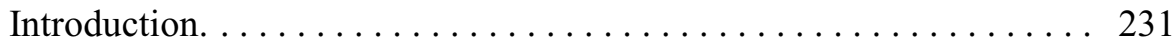

The Rule of Law in Domestic Law. . . . . . . . . . . . . . . . . . . . . 232

I. The Common European and American Heritage. . . . . . . . . 232

II. The Differing National Conceptions in Europe. . . . . . . . . . 240

(i) The German Rechtsstaat. . . . . . . . . . . . . . . 241

(ii) The French Etat de Droit. . . . . . . . . . . . . . . . . . 246

(iii) The English Rule of Law.................... 251

(iv) The supranational pan-European concept.......... 259

(a) The Rule of Law in the European Union. . . . . . . . 259

(b) The Rule of Law under the European Convention for the Protection of Human Rights. . . . . . . . . . . . . 269

(c) Assessment: The Added Value of the Pan-European Rule of Law. . . . . . . . . . . . . . . . . . 271

III. The Rule of Law in American Law. . . . . . . . . . . . . . . . . . 272

(i) The Natural Rights of Man. . . . . . . . . . . . 272

(ii) Due Process under the Fifth Amendment. . . . . . . . . 274

(iii) Due Process under the Fourteenth Amendment. . . . . . . . 276

(iv) The Supreme Court as the guarantor of the American Rule of Law. . . . . . . . . . . . . . . . . . . . . . . . 278

IV. The Rule of Law in China and the Rest of Asia.... . . . . . . 280

V. The Socialist Rule of Law. . . . . . . . . . . . . . . . . . . . 284

VI. The Rule of Law in Islam..................... 285

VII. The Rule of Law in Latin America and Africa.. . . . . . . . . . . . 287

VIII. Elements for a Universal Definition of the Rule of Law. . . . . . 288

The Rule of Law in International Law.. . . . . . . . . . . . . . . . 290

\footnotetext{
* Director, Legal Service, Council of the European Union, Professor of Law, Free University Brussels (VUB), Doctor of Laws (Spain), PhD (Cantab). The opinions expressed and the approach taken in this paper are personal to the author and in no way do they reflect the position of or engage the Legal Service of the Council or the Council itself.
} 
I. Is There an International Rule of Law? . . . . . . . . . . . . . . 291

II. The Implementation of the International Rule of Law. . . . . . . . 299

III. The Rule of Law in the External Action of the European Union.. 308

(i) The Union's predisposition to international law....... . 309

(ii) The legal means of EU external action on the Rule of



(iii) Political clauses in EU agreements. . . . . . . . . . . 312

(iv) The European Neighbourhood and Partnership Policy. . . . 313

(v) Pre-accession assistance. . ............... 320

(vi) EU development and economic, financial and technical assistance policies. . . . . . . . . . . . . 321

(vii) The Rule of Law in the Common Foreign and Security Policy of the Union. . . . . . . . . . . . . . . . . . . . . . . . 324

(a) The Rule of Law in EU Civilian Crisis Management Operations....................... 328

(b) The Rule of Law and EU Military Operations... . . . 334

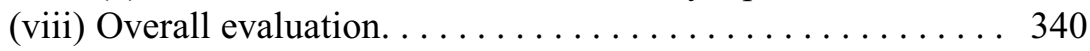

IV. The Rule of Law in the External Action of the United States. . . 344

(i) The United States and International Law. . . . . . . . . 344

(ii) The Rule of Law as a strategy in U.S. external action. . . . 348

(iii) A comparison between the EU and U.S. strategies on the

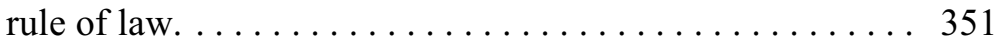

Are the European Union and the United States Allies or Competitors?. .............................. 353

Epilogue: A Universal Definition of the Rule of Law?... . . . . . . 360 


\section{INTRODUCTION}

Although the rule of law "is today universally recognised as a fundamental value," indeed the term "rule of law" is very fashionable at present, ${ }^{2}$ there is no universal agreement about what it means: "the rule of law has meant many things to many people $;^{3}$ nor is there agreement about how it can be "reconciled with other, competing, values, notably with the requirements of democratic government."

It is submitted in this paper, that any universal definition of the rule of law will have to incorporate all of the following four principles: (1) The principle that power may not be exercised arbitrarily. This principle requires a rejection of the rule by man and the notion that laws should be prospective, accessible, and clear; and (2) The principle of supremacy and independence of the law. This principle distinguishes the rule of law and requires acceptance of the principle of the separation of powers, which is the idea that the law applies to all, including the sovereign, and that there must be provisions for an independent institution, such as a judiciary, to apply the law to specific cases; (3) The principle that the law must apply to all persons equally, offering equal protection without discrimination. This principle requires that the law should be of general application and capable of being obeyed; ${ }^{5}$ (4) The principle of respect for universal human rights as laid down in the instruments and conventions accepted by the international community as a whole. The universal definition of the rule of law suggested in this paper results from an examination, undertaken in the following pages, of the evolution of the rule of law in the principal different systems of the world, and of the status of the rule of law in international law. This paper also examines the implementation and promotion of the rule of law by the different subjects of international law

1. Francis G. Jacobs, The Sovereignty of Law: The European Way 7 (2007).

2. T. Bingham, The Rule of Law 3 et seq. (Allen Lane Penguin 2010). See also the three-volume work by S. Holovaty, The Rule of Law (Kyiv, Phoenix Publishing House 2006); Brian Z. Tamanaha, The Rule of Law for Everyone?, 55 Current Legal Probs. 97 (2002).

3. Jeffery Jowell, The Rule of Law and Its Underlying Values, in The Changing Constitution (J. Jowell \& D. Oliver eds., Oxford Univ. Press 7th ed. 2011). See also Jeffery Jowell, The Rule of Law Today, in The Changing Constitution 57 (J. Jowell \& D. Oliver eds., Oxford Univ. Press 6th ed. 2007).

4. JACOBS, supra note 1 .

5. See Report on the Rule of Law adopted by the Venice Commission at its 86th plenary session (25-26 Mar. 2011), Council of Europe Doc. CDL-AD (2011) 003, Study No. 512, at 10 et seq. See Simon Chesterman, Rule of Law (2007), in MAX Planck EnCyClopedia OF Public International Law (2010), available at $\mathrm{http}: / / \mathrm{www} . \mathrm{mpepil.com}$. 
with a particular attention paid to the external action of the European Union and the United States.

\section{The Rule of Law in Domestic Law}

In Europe and the United States, the idea of the rule of law (hereinafter referred to as the rule or the idea) has a long and fascinating history.

\section{The Common European and American Heritage}

The idea of the rule of law has ancient roots in European political thought. It appeared as a rule of restraint in the exercise of political power by subjecting it to certain abstract principles. A "horizon of meaning of the rule of law" was elaborated by ancient Greek philosophers concerned about the potential for a democratic government to degenerate into a tyranny. The idea was already put into practice in Athens during the fifth Century B.C. where the Magistrates of the Polis, the democratic political community, could be charged with violations of the law by private citizens. ${ }^{7}$ Thus, Plato intended that, the legal code incorporated in his work The Laws, would be permanent in nature and insisted that the government should be bound by these laws because:

[W] here the law is subject to some other authority and has none of its own, the collapse of the state, in my view, is not far off; but if law is the master of the government and the government is its slave, then the situation is full of promise and men enjoy all the blessings that the gods shower on a state. ${ }^{8}$

Aristotle went further in stating:

Now, absolute monarchy, or the arbitrary rule of a sovereign over all citizens, in a city which consists of equals, is thought by some to be quite contrary to nature; . . . That is why it is thought to be just that among equals everyone be ruled as well as rule, and therefore that all should have their turn. And the rule of law, it is argued, is preferable to that of any individual; On the same principle, even if it be better for certain individuals to govern, they should be made only guardians and ministers of the law. . . . Therefore he who bids the law rule may be deemed to bid God and Reason alone rule, but he who bids man rule adds an element of the beast; for desire

6. Pietro Costa, The Rule of Law: A Historical Introduction, in The Rule of Law: History, Theory, And Criticism 73, 75 (Pietro Costa \& Danilo Zolo eds., 2007) [hereinafter The Rule of Law].

7. Brian Z. Tamanaha, On the Rule of Law: History, Politics, Theory 7 (Cambridge Univ. Press 2004).

8. Plato, The Laws 174 (Trevor J. Saunders trans., London, Penguin 1970) (355-347 B.C.). 
is a wild beast, and passion perverts the minds of rulers, even when they are the best of men. The law is reason unaffected by desire. ${ }^{9}$

This passage from Aristotle's work, Politics, raises most of the fundamental questions that have accompanied the discussions of European history on the idea of the rule of law, i.e. the question of self-rule in situations of political equality, of subjection of government officials to the law, and of identification of the law with reason which would protect the law from abuse by those who hold power. In particular, the contrast that Aristotle established between the rule of law as reason, and the rule of man as passion, became one of the recurrent questions throughout the European history of the philosophy of law. ${ }^{10}$

Both Plato and Aristotle considered the maximization of the common good of the community and the improvement of moral development as the aim (or the purpose) of law. Thus, according to Plato, law is a reflection of a divine order consistent with "The Good:" "the laws that are not established for the good of the whole state are bogus law"11 while Aristotle adds that "what is just will be both what is lawful and what is fair, and what is unjust will be both what is lawless and what is unfair." 12 Aristotle concluded that "true forms of government will of necessity have just laws, and perverted forms of government will have unjust laws," 13 and he added further that "laws, when good[,] should be supreme." ${ }^{14}$ However, neither Plato nor Aristotle advocated rebellion against the law, even against unjust laws, and neither of them approved of popular democracy, which was viewed as the potential rule of the uneducated and unintelligent mob susceptible to being seduced by demagogues. Also, neither were egalitarian since they both believed people had unequal talents in political capacity, virtues, and intelligence. According to Plato and Aristotle, the best government consisted of rule by the best man, not rule by law, for the law cannot foresee all eventualities. Therefore, Plato considered that "where the good king rules, law is an obstacle standing in the way of justice" 15 and Aristotle advocated rule under the law in order to avoid

9. Aristotle, Politics bk. iii, at 78 (Steven Everson ed., Cambridge Univ. Press 1988).

10. See TAmanaha, supra note 7, at 9 .

11. See generally Plato, supra note 8; Aristotle, supra note 9; Fred D. Miller, The Rule of Law in Ancient Greek Thought, in The Rule of Law in Comparative Perspective 11, 11 (Mortimer, Sellers \& Tadeusz eds., 2010) [hereinafter Comparative Perspective].

12. Aristotle, Nicomachean Ethics 117 (Terence Irwin trans., Hackett Publ'g Co. 1985).

13. ARISTOTLE, supra note 9 , at 68 .

14. Id.

15. Plato, quoted in John Walter Jones, The Law And Legal Theory of the Greeks 7 (Oxford, 
the risk of corruption and abuse that arises when power is concentrated in a single pair of hands. ${ }^{16}$ In contrast with the Athenian Democrats, who advocated the supremacy of the law created by all citizens in order to avoid the governance of the aristocratic oligarchies, Plato and Aristotle were concerned about how to avoid popular tyranny in a democracy. When criticising popular tyranny in democracies, Aristotle introduced the notion of sovereignty of law:

[S] uch a democracy is fairly open to the objection that it is not a constitution at all; for where the laws have no authority, there is no constitution. The law ought to be supreme overall, and the magistracies and government should judge of particulars. ${ }^{17}$

In the end, the most mature form of the rule of law achieved by Athens was one that ensured the equality of citizens before the law; the principle that laws had to be drafted in general terms; that the Athenian Council, magistrates, and legislative assemblies were bound by the law, and that citizens were free to operate as they wished under the law, provided that their actions were not prohibited by the law.

The Romans brought both positive and negative elements to the idea of rule of law, although the negative elements proved to be of much greater consequence. On the positive side, there was the work of Cicero, who continued the Greek tradition of Plato and Aristotle in The Republic, his masterpiece produced in the first Century B.C. There, Cicero commented that the king who does not abide by the law is a despot, "the foulest and most repellent creature imaginable." ${ }^{18}$ Furthermore, in his work, The Laws, while describing the function of the magistrate, Cicero points out that:

[The magistrate] is to take charge and to issue directives that are right, beneficial and in accordance with the laws. As magistrates are subject to the laws, the people are subject to the magistrates. In fact it is true to say that a magistrate is a speaking law, and the law a silent magistrate. ${ }^{19}$

According to Cicero, the status of the laws differed depending on their consistency with natural law. Natural law was the rule of reason, and

\footnotetext{
Clarendon Press 1956).

16. ARistotLe, supra note 9 , at 76 .

17. Aristotle, Politics bk. iv, at 89 (Steven Everson ed., Cambridge Univ. Press 1988).

18. Cicero, The Republic bk. ii, at 50, in The Republic and The Laws (Niall Rudd trans., Oxford Univ. Press 1998).

19. Cicero, The Laws bk. iii, at 150, in The Republic and The Laws (Niall Rudd trans., Oxford Univ. Press 1998).
} 
according to the rule of reason, law should be for the good of the community, it should be just, and it should preserve the happiness and safety of the citizens. This idea of natural law stood above positive and human law; it was a law that was consistent with justice and hence reigned supreme. ${ }^{20}$

The negative Roman contributions to the rule of law result from the Lex Regia and the Corpus Iuris Civilis. The Lex Regia provided a legitimation for the move from the rule of the Roman Republic to the rule of the Roman Emperor Constantine. Constantine managed to combine secular and religious power in a manner that many European monarchs would emulate for centuries by converting to Christianity and deciding to move the capital from Rome to Constantinople (Istanbul) in the year 306 A.D. According to the Lex Regia, the new power of the Roman Emperor derived from the absolute authority that the Roman people had bestowed on him for the preservation of the state, ${ }^{21}$ which was a legal fiction created by early Roman jurists in order to justify the power of the Emperor. This legal fiction enjoyed considerable authority during the Middle Ages both in the course of democratic thinkers elaborating on the idea of original popular sovereignty and on the development of the idea of the absolute authority of the king by the absolutist thinkers. ${ }^{22}$ The Corpus Iuris Civilis, which codified the Roman Law instituted by Emperor Justinian in 527 A.D., contains two maxims relevant to the idea of the rule of law: "Sed quod principi placuit legis habet vigorem," "what has pleased the prince has the force of law" and "Princeps legibus solutus est," "the prince is not bound by the law." ${ }^{23}$ The expressions illustrate, for the first time, the tension existing in the fact that the sovereign is both the source of law and subject to the law, a tension that the idea of the rule of law has attempted to reconcile within modern legal systems.

The concept of the rule of law continued to be enriched in the Middle Ages, a period in European history which lasted one thousand years, from the collapse of the Roman Empire in the fifth century A.D. until the Renaissance in the fifteenth and sixteenth centuries A.D. The sources of the contributions to the medieval concept of the rule of law are: the contest for supremacy between the kings and the popes, Germanic customary law, and the Magna Carta, which epitomised the efforts of nobles to use law to impose restraints on sovereigns.

\footnotetext{
20. TAMANAHA, supra note 7, at 11 .

21. Peter Stein, Roman Law in European History 59 (Cambridge Univ. Press 1999).

22. Brian Tierney, "The Prince is Not Bound by the Laws." Accursius and the Origins of the Modern State, 5 Comp. STUD. Soc’y \& Hist. 378, 392 (1963).

23. Digest 1.4.1 and Digest 1.3.1, cited in SteIN, supra note 21, at 59.
} 
One manifestation of the medieval concern for the rule of law is the importance that medieval authors accorded to the question of whether all men were subject to the law or, in terms of medieval dispute, "whether the prince was bound by the laws or not." 24 According to the traditional, feudal idea expressed by Bracton:

[T] he King must not be under man but under God and under the Law, because the Law makes the King . . . for there is no Rex where will rules rather then Lex . . . if he brakes the Law his punishment must be left to God . . . for the King cannot be sued or punished. ${ }^{25}$

But the opposite view appears in the Digest $(1,3,31)$, where the words of Ulpian 228 A.D. were recorded under the imperial authority of Justinian, that "the Prince is not bound by the law" which was originally recorded in Latin as "[p]rinceps legibus solutus est." Given the clarity of the pronouncement and the authority of the Digest, the Ulpian text could not possibly be ignored. But it did not necessarily mean that rulers were at liberty to act arbitrarily and operate above the law. Accursius (1184-1263 A.D.), a great lawyer of the thirteenth century A.D., who also was a glossator i.e. a lawyer devoted to the study, annotations, and explanations of Roman legal texts, made the impact of the maxim less severe by pointing to other passages in the Digest including the Code and the Institutes, which provide that even the Emperor had to obey the law. These include, C. 1, 14, 4: "re vera majus imperio est submittere legibus principatum," "it is worthy of the majesty of the ruler that the emperor should acknowledge that he is bound by the laws"; Inst. 2. 17. 8: "licet enim legibus soluti sumus, attamen legibus vivimus" "though we are not bound by the laws we live by the laws." Accursius seemed to indicate that the absence of authority in Roman law with the necessary jurisdiction to compel the Emperor, was an institutional defect, rather than a question of principle. ${ }^{26} \mathrm{But}$, it has been suggested that ever since, European legal thought has been divided between those who, like Jean Bodin, adhered to the absolutist theory, founded on the principle of "princeps legibus solutus est" and those who, like Bracton and François Hotman, considered the king subject to the law. ${ }^{27}$

24. R.C. van Caenegem, Legal History: A European Perspective 122-23 (1991).

25. 1 Henrici De Bracton, De Legibus Et Consuetudinibus Angliae 38 (Sir Travers Twiss ed., W.S. Hein 1990) (1878) (on laws and customs of England); Frederic William Maitland, The Constitutional History of England 100-01 (Cambridge Univ. Press 1963) (1908).

26. Tierney, supra note 22, at 378-400.

27. G. Rebuffa, Jean Bodin e il 'Princeps legibus solutus, in MATERIALI PER UNA STORIA DELLA cultura GiURidica 91-123 (G. Tarello ed., 1972); Julian H. Franklin, Jean Bodin and the Rise of 
The Middle Ages were a long and tumultuous period and the citizens during this time were not always law-abiding. Indeed, feuds were legal in the Middle Ages and law often regulated less and left more liberty than our present laws. However, the opposite also held true, e.g., the strict rules of the preuves savantes (evidences based on documents and witnesses as developed by Gratian, the canon lawyer), isolated the modern notion of discretionary assessment and the conviction intime or beweiswürdigung of judges, (the free evaluation of evidence by the judges according to their inner deep-seated convictions). ${ }^{28}$ There is no doubt that the idea of the rule of law was clearly perceived by medieval thinkers and practitioners and that it prevailed in certain periods and in certain countries during the Middle Ages. ${ }^{29}$

The question arises whether medieval law was observed and enforced against all subjects irrespective of their power or legal status. On one hand, medieval history went through certain periods of weak law enforcement, times which could be described as "lawless" and "anarchical." For example, after the breakdown of the Carolingian monarchy in ninth century France, the unscrupulous and despotic "robber barons" imposed illegal and immoral practices such as illegally charging tolls on passing merchant ships. Additionally, when the ordinary feudal machinery became deficient, strange ecclesiastical expedients like "the Peace and the Truce of God" were established in order to ensure a certain measure of protection from spiritual retribution through violence on the individual for certain categories of people and places at certain privileged dates and periods of the year. ${ }^{30}$ On the other hand, when the western monarchies increased their power, they subjugated these barons, demolished their "adulterine" castles, i.e. castles built without the approval of the superior lord, and submitted them to the royal courts, which afforded judicial protection to the ordinary man. Thus, legal historians have concluded that "given a minimum of political stability, the medieval

Absolutist Theory (1973); Francois Hotman, Franco-Gallia or an Account of the Ancient Free State of France (2007), quoted in VAN CAENEGEM, supra note 24, at 123.

28. J. Hilaire, la construction de l'Etat de droit 356 (Dalloz 2011) (study based on the judicial archives of the medieval France); J.P. LÉVY, LA HIÉRARCHIE DES PREUVES DANS LE DROIT SAVANT DU MOYEn-Age DEPUiS LA ReNAISSANCE DU DROIT ROMAIN JUSQU’À LA FIN DU XIVÈME SIÈCle 57 (Paris, Sirey 1939).

29. VAN CAENegem, supra note 24, at 146-47 and 14-16 (describing town charters which stipulated that in criminal cases the relevant article must be read out to make sure that the law is duly applied).

30. Hartmut Hoffmann, Gottesfriede und Treuga Dei, Schriften der Monumenta Germaniae Historica 20 (Stuttgart 1964). 
states offered a large measure of judicial protection even to their most ordinary citizens." ${ }^{\prime 1}$

Did the law prevail over the highest political authorities of medieval times? Numerous charters expressly excluded arbitrary rules, stipulated that the government was subject to the law, and guaranteed certain individual rights even though the enforcement mechanism ensuring observation of those charters was weak. Indeed, one of the main clauses of the English Magna Carta of 1215 provided the origin of the concept of habeas corpus, "we command to have the body," as follows:

No free man shall be seized or imprisoned, or stripped of his rights or possessions, or outlawed or exiled, or deprived of his standing in any other way, nor will we [the King] proceed with force against him, or send others to do so, except by the lawful judgement of his equals or by the law of the land.

The justification for this clause was that the King was at all times entitled to have an account of why the liberty of any of his subjects was restrained. But, whenever the king himself breached any provisions of the Carta, he was only subject to the control of the council of twenty-five barons which had no power of enforcement over the king, i.e. they could only threaten the king with civil war. ${ }^{32}$ Thus, although the government was bound by the law, the illegal arbitrary exercise of power was very rarely subject to institutional control. ${ }^{33}$ Indeed, the great majority of those charters lacked an enforcement mechanism to make them effective.

The four centuries that followed became a laboratory for these medieval ideas but, from a legal point of view, the idea of the rule of law did not receive further impetus until the seventeenth and eighteenth centuries. During that time, Europe experienced popular uprisings that gave birth to significant philosophical contributions to the theory of government and the rule of law. The most fundamental question was that of the source of legitimacy for governmental action and authority, since unquestionable adherence to monarchical rule had lost support. The negative contribution was provided by Hobbes, according to whom the sovereign, though bound in conscience by natural law, wields absolute untrammelled power. Therefore, the rule of law and the rule of will were always synonymous and equivalent. Furthermore, a

31. VAn CAENEgem, supra note 24, at 147.

32. J. C. Holt, Magna Carta 242-68 (Cambridge Univ. Press 1992) (1965).

33. Robert S. Summers, A Formal Theory of the Rule of Law, 6 RATIO JuRIS 127 (1993). See, e.g., S. Rutherford, Lex, Rex, The Law and the Prince (1644) (ed. 2002) where he supports the idea of a limited monarchy. 
rule was inherently powerless unless it was applied, interpreted, and enforced by individuals: "there must always be somebody who has the final word." ${ }^{34}$ In contrast, other legal philosophers, such as John Locke, Jean-Jacques Rousseau, and Count Montesquieu, provided a new legal basis for governmental authority and the rule of law. First, Locke suggested that legitimate governments had to be based on popular consent and that any action by any government that was not supported by popular consent was not valid and was "without authority." He also suggested the following concept of the rule of law:

[A]ll the power the government has, being only for the good of society, as it ought not to be arbitrary and at pleasure, so it ought to be exercised by established and promulgated laws; that both the people may know their duty, and be safe and secure within the limits of the law; and the rulers too kept within their bounds. . . ${ }^{35}$

These views of Locke prevailed over other ideas. Secondly, on the question of the proper structure of government, Montesquieu provided the most widelyfollowed contribution. He suggested that countries should elaborate constitutions as fundamental charters containing the original will of the people to be governed. He also underlined the importance of the separation and balance of powers between the legislative, the executive, and the judiciary when he stated that:

\begin{abstract}
When the legislative and the executive powers are united in the same person ... there can be no liberty; because apprehensions may arise, lest the same monarch or senate should enact tyrannical laws, to execute them in a tyrannical manner. . . . Again there is no liberty, if the judicial power be not separated from the legislative and executive. Were it joined with the legislative, the life and liberty of the subject would be exposed to arbitrary control; for the judge would be then the legislator. Were it joined to the executive power, the judge might behave with all the violence of an oppressor. ${ }^{36}$
\end{abstract}

Thirdly, there emerged the notion of the rights of individuals, i.e. the idea that individuals were entitled to certain rights of which they could not be deprived of either by the actions of government or by the actions of other individuals. This notion of individual rights, now known as human rights, was (1651).

34. Thomas Hobbes, Leviathan 176-79, 250 (J.C.A. Gaskin ed., Oxford Univ. Press 1996) (1690).

35. John Locke, Second Treatise of Government 46-51 (C.B. Macpherson ed., Hackett 1980)

36. Baron de Montesquieu, The Spirit of Laws bk. xi, at 202 (David Wallace Carrithers ed., Univ. of Cal. Press 1977) (1748). 
above all brought to fruition in the American Declaration of Independence in 1776. It proclaimed that all men were born free and equal and that the right to life, liberty and the pursuit of happiness were among those rights that are unalienable. That document declared:

We hold these truths to be self-evident, that all men are created equal, that they are endowed by the Creator with certain unalienable rights, that among these are life, liberty and the pursuit of happiness, to secure these rights, governments are instituted among men, deriving their just powers from the consent of the governed. ${ }^{37}$

In 1780, the Constitution of the state of Massachusetts reflected in its Article 30, the idea of separation of powers under the rule of law in the following terms:

In the government of this Commonwealth, the legislative department shall never exercise the executive and the judicial powers, or either of them; the judicial shall never exercise the legislative and executive powers, or either of them; to the end it may be a government of laws and not a government of men. ${ }^{38}$

Finally, the amalgam of concepts underlying the idea of the rule of law, such as the government submitting to the consent of those being governed, the principle of the separation of powers as an instrument of protection against any violation of the principle of popular consent, and the principle of the existence of inherent and inalienable individual rights were incorporated in the Constitution of the United States of $1789,{ }^{39}$ the French Declaration of the Rights of Man and the Citizen of $1789,{ }^{40}$ and the Bill of Rights of the United States of $1791 .^{41}$

\section{The Differing National Conceptions in Europe}

The amalgam of these concepts gave birth to the term "rule of law," which appeared when the common European heritage based on Roman law,

37. See Unanimous Declaration of the Thirteen United States of America, 1 Stat. 1 (1776). For a study, see D. Armitage, The Declaration of Independence: A Global History (2007).

38. Mass. Const. pt. 1, art. XXX, reprinted in The Founders' Constitution: Fundamental Documents, vol. I, ch. 1, doc. 6, at 13-14 (Philip B. Kurland \& Ralph Lerner eds., Liberty Fund, Inc. 2000).

39. S. ReP. No. 108-17 (2004).

40. Declaration of the Rights of Man and the Citizen, reprinted in The Columbia ENCYCLOPEDIA (6th ed. 2008).

41. U.S. Const. amends. I-X. See The Bill of Rights and the States (Patrick T. Conley \& John P. Kaminski eds., 1992). 
the Medieval Jus Commune, natural law, and the enlightened secular law of reason was transposed, in the context of the establishment of sovereign states, into differing national laws.

\section{(i) The German Rechtsstaat}

The term Rechtsstaat originated in Germany in 1798 as a neologism combining the words "law" and "state," thus putting more emphasis on the nature of the state than on the judicial process. Due to the link that the concept of Rechtsstaat establishes between law and the state, it is common understanding that Immanuel Kant is the spiritual father of the German term, even though Kant himself never used it. Indeed, in his Theory of the State, Kant defined the state as the union of a multitude of men under laws of justice with any "lawful state" necessarily being a state governed by the law of reason, i.e. the law based on the principles of freedom of every member of society, equality, and of individual autonomy. Furthermore, the laws of the State were required to preserve and promote these principles. ${ }^{42}$ The neologism Schule der Rechts-Staats-Lehre was apparently first used by Johan Wilhelm Placidus in his Litteratur der Staatslehre, Ein Versuch ${ }^{43}$ and was then popularized by Robert von Mohl, who contrasted the Rechsstaat with the aristocratic police state. He defined the main objective of a Rechtsstaat as "organi[zing] the living together of the people in such a manner that each member of it will be supported and fostered, to the highest degree possible, in the free and comprehensive exercise and use of his strengths." ${ }^{44}$ According to von Mohl, the guiding light of any state action is individual freedom, and, for that purpose, the state has an obligation to respect all laws and customs, to take account of the dispositions and particular inclinations of its people, and

42. The definition of "lawful state" by Kant exerted a considerable influence on the liberal theories of constitutional law which developed in Germany in the first half of the nineteenth century. See M. Brocker, Kant über Rechtsstaat und Demokratie (VS Verlar 2006); Donald P. Kommers, The Constitutional Jurisprudence of the Federal Republic of Germany 36-37 (2d ed. 1997) (1989). For instance, for an account of the difference in origins and concept between Rechtsstaat, Etat de droit and Rule of Law, see M. Loughlin, Foundations of Public Law ch. 11, 312-37 (Oxford Univ. Press 2010).

43. J.W. Placidus, Litteratur der Staatslehre. Ein Versuch (1798).

44. Robert von Mohl, Die Polizeiwissenschaft nach den Grundsätzen der RechtstaAtes 8 (Tübingen, Laupp 1844). Robert von Mohl opposes the suggestions made by F.J. Stahl that Rechsstaat simply refers to a state acting in a legal form and purporting to "exactly determine and unquestionably establish the lines and boundaries of its actions as well as the free ambits of its citizens in accordance with the law (in der Weise des Rechts)." Friedrich Julius Stahl, Die Philosophie Des Rechts, II 195-96 (Tubingen 1878, Hildesheim-Olms 1963); see Costa, supra note 6, at 90-91. See K. Sobota, DAS PrinZIP RechtsstaAt 306 et seq. (M. Siebeck 1977). 
to respect private property as the unavoidable condition for individual development.

The concept of Rechtsstaat was much used in the course of the nineteenth century A.D. during which Germany experienced an extraordinary development of public law mainly as a result of the Restoration which followed the 1848 revolts. The development of public law was prompted by the outstanding theoretical contributions of G. Jellinek, O. Mayer, and R. von Jhering. Politically, this development epitomised a compromise between liberal doctrine, support of the bourgeoisie, and authoritarian ideology supported by conservative forces such as the monarchy, the rural aristocracy, and senior military bureaucracy. The Rechtsstaat as defined by the German publicists was based on three elements: the theory of the "state's selflimitation," the theory of "subjective rights," and the theory of the "primacy of law."

According to the theory of the "state's self-limitation," the state as sovereign was not conditioned by any external limit. Instead, the state was restrained by its free decisions owing either to the pressure that society exercised on the state ${ }^{45}$ or to the counteracting effect of "mature civilised people." 46 The theory of "subjective public rights" represented a statist conception of rights, i.e. individual rights were established by the sovereign authority of the state, which thereby imposed limits on its own freedom of action. These individual rights were the result of popular sovereignty as theorized by the French revolutionaries and did not include the "right of resistance" to the state. ${ }^{47}$ The power to establish individual rights within a state belonged to the legislator, i.e. "statutory reservation." Individual rights were not of a pre-political origin, as they were discussed through Locke's contractualism, or of a religious nature and thus based on a transcendent and universalist natural law.

In this Rechtsstaat there were different categories of individual rights. The first category included those rights resulting from the status passivus or status subjectionis, where individuals had only duties and no rights as in the case of the duty to perform military service. The second category included those resulting from the status negativus or status libertatis, where individuals possessed a right to be free which derived from history as prescribed by the

\footnotetext{
45. R. von Jhering, Der Zweck im Recht [Law as a Means to an End] (Goldbach, Keip 1997)

46. G. Jellinek, Allgemeine Staatslehre (1919).

47. C. Sсhmitt, Legalität und Legitimität, in Verfassungs ReChtliche Aufsätze aus dem JAHREN 1924-1954, at 264, 276-77, 279 (J. Seitzer trans., 2004) (1932).
} (1877). 
legislator. In the context of the status negativus, "every freedom [was] nothing but the exemption from illegal constraint." There were those rights resulting from the status positivus or status civitatis, where the state conferred on the individual subjective public rights in the form of capacities and remedies such as the right to have an administrative act annulled. Finally, there were those rights resulting from the status activus or status activae civitatis, or the political rights of the citizen. ${ }^{48}$ In this latter Rechtsstaat, the law was supreme, it referred to the theory of primacy of law, and it comprised a system of impersonal, abstract, general, and non-retroactive rules governed by the "principle of legality" (originally termed Gesetsmässigkeit).

According to the principle of legality, the acts of Parliament had to be rigorously respected by the executive and judicial powers. This obligation to respect the law was the most effective defence against any political misuse of powers and constituted the supreme guarantee for the protection of individual rights. However, the nineteenth century A.D. theory of the Rechtsstaat failed to take into account the potential arbitrary use of legislative power, sic volo or sic jubeo, and was too optimistic in taking for granted the trust of the citizens since it assumed a perfect correspondence between the will of the state, legality, and moral legitimacy. This Rechtsstaat became a mere "law of the state" or Staatsrecht, characterised by a purely technical and formal concept of law, which consisted of both general and abstract norms, detached from ethical and political contents, (except the protection of freedom and property), without providing for constitutional review. Under these conditions, the Rechtsstaat was soon regarded as legalistically vacuous, or as a tautological, procedural, and a mere legal state.

At the end of the nineteenth century A.D., a turbulent period in the history of the Rechtsstaat commenced. The concept either retained a meaning only in administrative law, where the concept was transformed into a mere principle of legality ${ }^{49}$ or was made a subject of derision by Bismarck as an "artificial expression or Kunstausdruck invented by Mohl, on which nobody has yet found a satisfactory definition for the body politics. ${ }^{50}$ Others likened the term

48. G. Jellinek, System der subjectiven öffentlichen Rechts 95-97, 102-03 (1905), discussed in Gustavo Gozzi, Rechtsstaat and Individual Rights in German Constitutional History in THE RuLE OF LAW, supra note 6, at 237, 248-49.

49. See Otto Mayer, Deutsches Verwaltungsrecht (1895), quoted in Laurent Pech, The Rule of Law in France, in Asian Discourses of Rule of LAw: Theories AND IMPLEMENTATION OF Rule of Law in Twelve Asian Countries, France and the United States 76, 80 (Randall Peerenboom ed., 2004) [hereinafter Asian Discourses of Rule of LAw].

50. Letter addressed by Bismarck to Minister van Gossler on 25 November 1883, in L. HensChLING, Etat de Droit, Rechtsstaat, Rule of Law 6 ( 2002). 
Rechtsstaat to an all-purpose notion, "magic box," or zauberkiste from which an ingenious spirit could take out, by means of a magical trick, any suitable legal principle or claim. ${ }^{51}$ As further evidence of the total malleability of the term, some lawyers did not hesitate to describe the Third Reich as an exemplary Rechtsstaat, ${ }^{52}$ Carl Schmitt (1888-1985) justified the fact that the Hitlerian state had its own Rechtsstaat based on the idea that there existed as many Rechtsstaat as states ${ }^{53}$ and that the Hitler state could be described as the "Deutsche Rechststaat Adolf Hitlers" or "the German Rechtsstaat of Adolf Hitler. ${ }^{54}$ In particular, Otto Koellreutter (1883-1972) defended the eternal nature of the idea of Rechtsstaat, which he defined as "a state based on order" or Ordnungstaat. ${ }^{55}$ Therefore, since the Third Reich had a legal order, it was a Rechtsstaat.

Later, legal positivism emphasized the formal aspect of the Rechtsstaat. ${ }^{56}$ In particular, it transformed the Rechtsstaat into the radical theory introduced by the Austrian Hans Kelsen, according to whom the state was not a real entity but a theoretical object created by jurists. According to Kelsen, the state was a set of norms which personified the legal system. The state was not power, but law. Therefore, all state organs had to be placed on an equal footing to any other legal subject. According to Kelsen, the Rechtsstaat "is determined in all its activities by the legal system" and this legal system is hierarchical, with a Grundnorm or superior norm at the top, such as a constitution that allows for constitutional control. ${ }^{57}$

At present, a mixed formal and substantive concept of the Rechtsstaat has gained an unprecedented popularity in Germany. The 1949 German Basic Law or Grundgesetz has enshrined the Rechtsstaat as a fundamental principle in its

51. G. Püttner, Vertrauensschutz im Verwaltungsrecht, in VeröFfENTLICHUNGEN DER Vereinigung Der Deutschen StaAtsRechtlehrer vol. 203 (1974).

52. C. Schmitt, Nationalsozialismus und Rechtstaat, in JuRistische WochenSCHrift 716(1934).

53. There was a federal Rechtsstaat, a corporativist Rechtstaat, a bourgeois Rechtsstaat, a Rechtsstaat based on natural law, a Rechtsstaat based on the law of reason so that each one chooses the Rechtsstaat to qualify the political regime that each one favours. "Recht aber soll vorzüglich heissen, was ich und meine Gervattern preisen.” See C. Schmitt, Legalität und Legitimität 18 (Berlin, Humblot 5th ed. 1993).

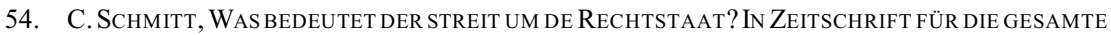
STAATSWISSENSCHAFT 10 (1935).

55. O. Koellreutter, Deutsches Verfassungsrecht Ein Grundriss 12 (Gunther \& Dürmhaupt 3d ed. 1938).

56. O. Mayer, Deutsches Verwaltungsrecht 61 (Dunker \& Humblot 1 st ed. 1985).

57. H. Kelsen, HauptProleme der StaAtSRechtslehre (1984); H. Kelsen, Staat und Recht, in Soziologische Hefte 18-37 (1922); H. Kelsen, RechtsstaAt und StaAtSRecht 36 (1913); H. Kelsen, La GiUstiZia CostituZionaLe 199 (1981). 
Article 28, Paragraph 1, according to which "[t] he constitutional order in the states must conform to the principles of the republican, democratic and social state under the rule of law." The terms "republican, democratic and social state" were taken from the constitutions of the Länder. With constitutional practice, the concept of Rechtsstaat has evolved into a constitutional principle informing all the activities of the state under the law. It also includes fundamental organizational principles, e.g.: the separation of powers, the constitutional judicial review undertaken by the German Constitutional Court or Bundesvervassungsgericht, the principles of legality, fair procedure, and legal certainty, and the principle of proportionality. Despite its extreme popularity, both in the legal literature and with the Constitutional Court, the present Rechtsstaat has not managed to escape criticisms that underline its relative and elusive nature. As we have seen, "the problem surrounding the study and the definition of the Rechtsstaat start with the very word." ${ }^{18}$ It has questionable dogmatic value, it covers many of the different principles already guaranteed in the Basic Law, ${ }^{59}$ and indeed, its very usefulness is questionable since the Rechtsstaat is little more than a pleonasm, redundant with the concept of staat. ${ }^{60}$

The term Rechtsstaat was exported from Germany to the rest of continental Europe starting at the end of the XIX century, giving birth to the French Etat de droit, the Italian Stato di diritto, the Spanish Estado de Derecho, the Dutch Rechtstaat, the Russian Prawowoje gosudarstwo as well as to the regional supranational Community of $\mathrm{law}^{61}$ or Union of $l a w^{62}$ in the case of the European Union. In the 1970s, the German constitutional construction of the Rechtsstaat as a constitutional principle informing all the actions of the state, was incorporated into Article 1, Paragraph 1, of the Spanish Constitution of 1978, into Article 2 of the Portuguese Constitution of 1976, and into most of the constitutions adopted by the Eastern European countries after the collapse of communism. ${ }^{63}$ It was also adopted outside

58. R.C. Van Caenegem, The Rechtstaat in Historical Perspective, in Legal History: A European Perspective 185 (1991); K.A. Schaditschneider, PrinziPien des RechsstaAtes (Duncker \& Humblot GmbH 2006).

59. Philip Kunig, Das Rechtstaatsprinzip: Überlegungen zu seiner Bedeutung für das VerfassungsRecht der BundesRepublik Deutschland (1986).

60. Hans Kelsen, Reine Rechtslehre 314 (2d ed. Wien 1992) (1960). In English—the book is Pure Theory of Law.

61. Case 294/83, Parti écologique Les Verts v. Parlement, 1986 E.C.R. 1339.

62. C.J. Rideau, De la Communauté de droit À L'Union de droit (2000).

63. Romanian Constitution of 1991 art. 1, $\uparrow 1$, art. 37, $₫$ 2; Bulgarian Constitution of 1991 pmbl., art. 4, $\uparrow$ 1; Czech Constitution of 1992 pmbl., arts. 1-2; Slovak Constitution of 1992 arts. 
Europe in Latin American ${ }^{64}$ and Asian ${ }^{65}$ legal systems, although they were also influenced by the constitution of the United States.

\section{(ii) The French Etat de Droit}

The idea, not the expression, of the rule of law took on idiosyncratic characteristics in revolutionary France. ${ }^{66}$ It was linked to the idea of constitutional governments and was introduced by Montesquieu in De l'esprit des lois. Montesquieu, looking to the English system as a model, considered the idea of Constitution as the "indispensable term to describe the fundamental order of a state, the model of political existence of a nation or people, the essential disposition of the elements or powers composing a form of government." He added that, in order to ensure liberty, "legislative, executive, and judicial power must be kept separated." However, it was necessary that the judicial power be subordinate to the legislative power, as the sole function of the judge was to apply the law. "[T] he judges of the nation are ... nothing but the mouth which pronounces the words of law ... some inanimate beings who cannot moderate either the force or the rigor of the law." ${ }^{67}$ Accordingly, Article XVI of the Declaration of the Rights of Man and the Citizen of 1789 provided that "[a]ny society in which the guaranty of rights is not assured or the separation of powers established, has no Constitution." Thus Montesquieu and the Declaration equated constitutional government with two decisive components of the rule of law, the separation of powers, and the protection of human rights.

There are several reasons that explain the absence of the term rule of law in French legal history. The first reason is that there was no need for a distinct concept given the fundamental and central importance of three other terms in French legal vocabulary: Nation, Etat, and République. ${ }^{68}$ On the one hand, the

1, 134, $\uparrow$ 4; Lithuanian Constitution of 1992 art. 7; Estonian Constitution of 1992 art. 10; Hungarian CONSTITUtion Of 1999 pmbl. and art. 2, 1 1; the New Fundamental Law of Hungary of 2011, at art. B, 1; Russian Constitution of 1993, at art. 1; Polish Constitution of 1997, at art. 2. See Notes on Constitutional Courts and the Rule of Law, 12 AM. U. J. INT'L L. \& PoL'Y 87 (1997) (a study of the Constitutional review in Russia and Eastern Europe).

64. See Russell H. Fitzgibbon, The Process of Constitution Making in Latin America, 3 Comp. STUD. Soc'y \& Hist. 1 (1960).

65. See generally Asian Discourses of Rule of LAw, supra note 49.

66. Marc Loiselle, Le Concept d'Etat de droit dans la doctrine juridique française (2000)

(unpublished Ph.D. dissertation, Université de Paris II) (on file at Université de Cergy-Pontoise).

67. Montesquieu, supra note 36, at 209.

68. See Pech, supra note 49, at 81 (describing the distinction between Etat and République). 
fundamental political change brought about by the French Revolution started a gradual process of transfer of sovereignty from the monarch to a new abstract entity which substituted the people for the King. This new abstract entity was to be known as the Nation ("all sovereignty resides essentially in the Nation," Article III of the Declaration) ${ }^{69}$ On the other hand, the French word République was given multiple meanings: it could imply not only a government of the people, by the people, and for the people, but also the principles enshrined in the 1789 Declaration, i.e. freedom, equality, and solidarity. In particular, according to Jean-Jacques Rousseau, Du contrat social (1762) laws voted by the people had sacrosanct and infallible qualities. He identified the rule of law with the rule in accordance with the will of the people and the supremacy of law with the supremacy of Parliament, the institution where the representatives of the people carried out the will of the people. Thus, according to Rousseau, "tout état régi par des lois" or "every state governed by law" was a République..$^{70}$ For Rousseau the words Etat and République or "a res publica" were equivalent. The term Etat usually referred to the principle that political power was subject to the law. Furthermore, Montesquieu described the State as a "société où il y a des lois" or "society where there are laws." 71 Given this background, the French translation of the German Rechtsstaat as Etat de droit was considered meaningless. It was difficult to see what could be meant by a State which was not a State governed by law: a society governed by arbitrariness could not be a State, since the mere existence of the State implied its subjection to the law. Thus in France, the concepts of Nation, State, and Republic incorporated the basic principles associated with the concept of the Rechtsstaat. ${ }^{72}$

The second reason for the absence of the term Etat de droit in French legal history has been identified as the result of a lack of stable constitutionalism. ${ }^{73}$ Revolutionary France adopted five constitutions in fifteen years ${ }^{74}$ namely, a constitutional monarchy, a radical republic, a moderate

69. E. Siéyes, Qu'est-ce-Que c'est le Tiers Etat? (Blondel trans. \& Finer ed., Frederick A. Praeger, Inc. 1964) (1789).

70. Jean-Jacques Rousseau, The Social Contract or Principles of Political Right 61 (Charles M. Sherover trans., The New American Library 1974) (1762).

71. Montesquieu, supra note 36, at 199.

72. Daniel Mockle, L'état de droit et la théorie de la rule of law, 35 CAHIERS DE DROIT 823 (1994) (Can.).

73. See Pech, supra note 49, at 81 (explaining that between 1789 and 1959 , in addition to 16 constitutions, France had 21 "semi-constitutional governments" and "de facto regimes").

74. Constitution of 3 September 1791; Constitution of 24 June 1793; Constitution of 26 August 1795; Constitution of 13 December 1799; and Constitution of 18 May 1804. 
reaction, a consulate, and finally a dictatorship. During the nineteenth century, from 1814-1875, each important political change resulted in a new constitution. ${ }^{75}$ Each constitution shaped the structure of government and the fundamental values of the state in a different way. It has been suggested that the reason for the French constitutional instability can be found in the difference between the French and the American revolutions. ${ }^{76}$ While the American Revolution arose against alleged abuses of public power, the French Revolution turned against the oppression of certain powerful private social groups, which were the remnants of the feudal system, and against the power and privilege of the Church and aristocracy protected by the judiciary. ${ }^{77}$ Thus, the revolutionary programs which expressed the aspirations of American and French societies were embodied in documents which necessarily took different forms:

[A] Constitution in the United States, with its emphasis on the separation and limitation of [public] power; and a code of private law in France (Code civil), based on the principles of legislative supremacy, equality, the personal and economic autonomy of the individual, and the right to property. ${ }^{78}$

However, the most fundamental explanation for the weakness of constitutionalism in France derives from the association of the idea of human rights with the principle of legislative supremacy and from the distrust of judicial power which precluded any effective judicial review of statutory law. ${ }^{79}$

Thus, a genuine and explicit French theory of the Etat de droit was only very belatedly formulated during the Third Republic, in the early decades of the twentieth century, by some professors who supported the idea of judicial review of statutory law and the end of the supremacy of Parliament. In particular, the Alsatian Jurist R. Carré de Malberg conceived a theory of the Etat de droit, under the influence of the German and American experiences, as an alternative model to unstable French constitutionalism and, in particular,

75. Charter of 4 June 1814; Charter of 14 August 1830; Constitution of 4 November 1848; Constitution of 14 January 1852; Constitutional Laws of 24-25 February and 16 July 1875.

76. Pech, supra note 49 , at 81 .

77. Alexis de Tocqueville, L’Ancien régime et la Révolution (Gerald Bevin trans., Penguin Classics 2008) (1856). See also Francois Furet \& Mona Ozouf, A Critical Dictionary of the French Revolution (Arthur Goldhammer trans., Belknap Press of Harvard Univ. 1989) (1988).

78. Martin A. Rogoff, A Comparison of Constitutionalism in France and the United States, $49 \mathrm{ME}$. L. REV. 23 (1997).

79. Pech, supra note 49, at 82; Mauro Cappelletti, The Judicial Process in Comparative Perspective 190-98 (1989). 
the institutions of the Third Republic. ${ }^{80}$ Like the German liberal jurists, Carré de Malberg believed that the main aim of the Etat de droit was the protection of individual rights against the potential arbitrariness of the state and for this purpose the state had to "self-limit" its sovereign power by requiring it to respect valid rules which had a general, erga omnes effect. According to Carré de Malberg, the protection of individual rights necessitated a profound reassessment of the French constitutional tradition and the French revolution. In particular, he questioned the omnipotence of Parliament since this institution had become the depository of national sovereignty, of a pre-legal and unlimited "constituent power," or pouvoir constituant which was the exceptional power of the people when they act directly and create a new constitution, and of the "constituted power," or pouvoir constitue according to which Parliament acts within the Constitution in the realm of policy. ${ }^{81}$

Carré de Malberg questioned the primacy of Parliament as depository of the revolutionary theory of popular or national sovereignty over the other powers of the state. He also disagreed with the conception proposed by Rousseau that law was the expression of the nation's general will whose prescriptions rigorously bound the executive power. Finally, Carré de Malberg also questioned the "Jacobin tradition" 82 of the revolutionary mistrust of judges. He proposed an understanding of the rule of law which submitted all powers, including the legislative power, to the law. In particular, Parliament had to be viewed only as a "constituted power" and administrative acts in addition to being submitted to the principle of legality, which corresponded to the condition of the legal state or Etat légal, had to ensure the full protection of the rights and liberties of the individuals. These rights and liberties could only be guaranteed by the Etat de droit, that is, the State equipped with the legal means to ensure that the individuals would be in a position to oppose the will of the parliamentary legislator acting in breach of fundamental rights. ${ }^{83}$ Thus, while the Etat légal purported to ensure the

80. M.J. Redor, De l'Etat légal À L'Etat de droit, L'Évolution des Conceptions de la doctrine publiciste franÇAise, 1879-1914 (Economica 1992); 1 Raymond Carré de Malberg, CONTRIBUTION À LA THÉORIE GÉNÉRALE DE L'ETAT 140 (1920-22).

81. This distinction was proposed by the prestigious E. Sieyès in his essay "Qu'est-ce que le tiers état?" SIEYÈs, supra note 69. The English version entitled "What is the third state?" may be found in Sieyès, Political Writings 35, 135-40 (Michael Sonenscher ed., Hackett 2003).

82. The Jacobin Club was the most famous political meeting room of the French Revolution; it was so-called after the Dominican convent were the members of the club met in Rue St. Jacques (in Latin: Jacobus) in Paris.

83. MAlBerg, supra note 80, at 488-92; Alain Laquièze, Etat de Droit and National Sovereignty in France, in THE RULE OF LAw, supra note 6, at 261, 265-66. 
legislative supremacy of Parliament, the Etat de droit was designed to protect the rights and liberties of the individual against arbitrary action of the parliamentary majority. Finally, Carré de Malberg argued that, considering the evolution of French law, the aim of the Etat de droit could not be achieved in France by means of judicial review of legislation of the American type. He proposed instead a clear distinction between the Constitution and ordinary laws placing the former above the latter and compelling Parliament to respect all the legal limits laid down by the Constitution, thus relinquishing any constituent claim. ${ }^{84}$

Since the conception of the Etat de droit proposed by Carré de Malberg precluded any effective judicial review of statutory law, it failed to put an end to the supremacy of Parliament. This failure explains the disappearance of the concept of the Etat de droit in French legal doctrine until the twentieth century. ${ }^{85}$ At the beginning of the twentieth century, the expression Etat de droit re-emerged, promoted by those professors who favoured the incorporation into French law of the principle of judicial review of statutory law. The expression Etat de droit made its initial appearance in a French dictionary in $1938^{86}$ and gained some popularity after the Second World War, without, however, being used frequently. ${ }^{87}$ Until recently, French lawyers have not been quite at ease with the Germanic Rechtsstaat, although at present they give the impression that they are slowly accepting the term Etat de droit as a literal translation of the German neologism Rechtsstaat.

The symbolic starting point of a new influence exercised by the concept of Etat de droit was the speech given on November 8, 1977 by Valéry Giscard d'Estaing, the President of the French Republic, in the Conseil Constitutionnel, the French equivalent of a constitutional court and one of the major innovations of the Constitution of the Fifth Republic. Giscard d'Estaing indicated that: "when each authority, from the modest to the highest, acts under the control of a judge who ensures that this authority respects the entirety of formal and substantive rules to which it is subjected, the 'Etat de droit' emerges." ${ }^{\text {" }}$ Indeed, the France of the Fifth Republic upheld two

84. MALBERG, supra note 80, at 493-500; and Costa, supra note 6, at 111.

85. Luc Heuschling, Etat de droit, RechtsstaAt, Rule of Law n.392 (2002).

86. VAN CAENEGEM, supra note 58, at 185-86 (explaining that the expression is found, inter alia, in a paper by De Visscher, published in 1946, and in the writings of Ellul in 1956 and Duverger and Vedel, both in 1973 and indicating that in post-war dictionaries the term can be found in the second edition of Debbasch and Daudet's Lexique of 1978 and that it is striking that the index of Prélot's Manuel contains droit de l'Etat, but not Etat de droit).

87. L.E. Marcel, Dictionnaire de Culture Religieuse et CATÉChistique (1938).

88. Quoted by Jacques Chevallier, L'Etat de Droit 128 (2d ed. 1994). 
fundamental ideas of the Etat de droit, namely (1) the judicial review of statutory law by the conseil constitutionnel, which elevated the status and importance of the Constitution and constitutionally based decision-making in the political life of the nation ${ }^{89}$ and (2) the limitation of executive power by courts pursuant to substantive constitutional standards. Today, France, an old democracy that has met the criteria of the rule of law for a long time, can also be formally described as an Etat de droit ${ }^{90}$ if we believe the standard conception of French constitutional doctrine according to which the state must act exclusively in a legal manner, i.e. in accordance with the principle of legality or the Etat légal and the notion that the state is subject to the law in accordance with the principle of constitutionality or the Etat de droit. This conception of the Etat de droit essentially equates the Etat de droit with judicial review of statutory law in accordance with formal and substantive rules laid down in the Constitution, which is placed at the top of the hierarchy of norms. ${ }^{91}$

(iii) The English Rule of Law

Until its entry into the European Union and the incorporation of the European Convention on Human Rights into English law, England did not possess many of the features which German, French, or American laws attribute to the rule of law. England has no written constitution, no explicit bill of rights in the modern sense, and no judicial review of Acts of Parliament. Yet, England is considered to be the bastion of the rule of law. This is so for very idiosyncratic historical legitimate reasons. As we have seen, in England the notion of law as a primary means of subjecting political power to control, appeared as early as the thirteenth century A.D. with Bracton. Based on the medieval idea of a universal natural law, Bracton maintained that, since law makes the King "the King shall not be subject to men, but to God and the law." 92 This theory was taken on by the Magna Carta and its subsequent confirmations as a means to provide a remedy for the grievances of certain classes of individuals within the community.

89. See Alec Stone, The Birth of Judicial Politics in France: The Constitutional Council in Comparative Perspective (1992); F.L. Morton, Judicial Review in France: A Comparative Analysis, 36 Ам. J. СомР. L. 89 (1988).

90. Laquièze, supra note 83, at 261; J. Chevallier, L'ETAT DE DROIT, Montchrestien, 2003).

91. Louis Favoreu, Légalité et constitutionalité, in 3 Les CAHIERs du Conseil Constitutionnel 33 (1997); Louis Favoreu et al., Droit constitutionnel 116-18 (4th ed. 2001).

92. A.W. Bradley \& K.D. Ewing, Constitutional and Administrative Law 99 (14th ed. 2007). 
In the sixteenth century A.D., the medieval idea of a universal natural law did not gather the same pre-eminence. Renaissance and reformation put the emphasis on the national legal system as an aspect of the sovereignty of the state. ${ }^{93}$ However, it was not until the seventeenth century that a struggle between Crown and Parliament led to a rejection of the "Divine Right of Kings" and to an alliance between common lawyers and Parliament. In particular, Sir Edward Coke advocated the supremacy of the common law as an objective law, ensuring the primary condition of freedom, constituting a limitation to the power of the monarch, and ensuring the protection of personal freedom and human rights. According to Coke, the common law "is the surest sanctuary that a man can take, and the strongest fortress to protect the weakest of all," and the objective application of the common law by the courts provides individuals with "a birth right" or protection that enables everyone to be free and keep safe his life, honor, family, and patrimony. ${ }^{94}$ It took a civil war, the beheading of the monarch, the overthrow and exile of the second monarch, the 1640 abolition of the Court of Star Chamber, ${ }^{95}$ (which drew its authority from the King's sovereign power and was not bound by the common law), the adoption of the Act declaring the Rights and Liberties of

93. Id. at 95; see also Alexander Passerin d’Entrèves, The Notion of the State: An Introduction to Political Theory 86 (1967); Maitland, supra note 25, at 100-04. For the rule of law in 16 th century England, see G.R. Elton, Studies in Tudor and Stuart Politics and Government 260-84 (1974).

94. 1 Edward Coke, The Second Part of the Institutes of the Laws of England 55 (R.H. Helmholz \& Bernard D. Reams, Jr. eds., William S. Hein Co. 1986) (1642).

95. The Court of Star Chamber was so named for the star pattern on the ceiling of the room where its meetings were held at Westminster Palace. It was established in 1487 as a judicial body which evolved from the medieval King's Council. It dealt inter alia with government administration and public corruption. The case of Entick v. Carrington constitutes a good illustration. In that case, two King's messengers were sued for having unlawfully broken and entered the plaintiff's house and seized his papers: the defendants relied on a warrant issued by the Secretary of State ordering them to search for Entick and bring him with his books and papers before the Secretary of State for examination. The Secretary of State claimed that the power to issue such warrants was essential to government, as being "the only means of quieting clamours and sedition.” Entick v. Carrington, (1765) 95 Eng. Rep. (K.B.) 807; 19 How. St. Tri. 1030, 1064. The court held that, in the absence of a statute or a judicial precedent upholding the legality of such a warrant, the practice was illegal. Lord Camden explained:

What would the Parliament say, if the judges should take upon themselves to mould an unlawful power into a convenient authority, by new restrictions? That would be, not judgment, but legislation .... And with respect to the argument of State necessity, or a distinction that has been aimed at between state offences and others, the common law does not understand that kind of reasoning, nor do our books take notice of any such distinctions.

Id. at 1067,1073 . This judicial decision stressed the value of personal liberty, and the necessity of protecting private property against official interference; it excelled in showing that the rule of law is the best form of protection against arbitrary action by the executive power and it still exercises considerable influence on judicial attitudes to the claims of government. See BRADLEY \& EWING, supra note 92, at 95. 
the subject, (the Bill of Rights Act of 1689), and the establishment of the succession to the English throne, before English law made the monarchy subject to the law. The Crown was thereafter forced to govern through Parliament and the right of individuals to be free from unlawful interference in their private affairs was established. Most importantly, the 1689 Act provided, inter alia, that it was illegal for the sovereign to suspend (Section 1) or dispense (Section 2) with laws, to establish his own courts (Section 3), or to impose taxes without approval by Parliament (Section 7). The Act also provided for free elections. At the same time, the procedure for habeas corpus was being developed as a remedy, writ, or legal action through which a person could seek a relief by the judicial power from unlawful detention. In particular, by means of "the writ of Habeas Corpus ad subiciendum," the court could order that a prisoner be taken before the court in order to determine whether a prisoner had been lawfully detained or should be released (Habeas Corpus act 1679). ${ }^{96}$

The nineteenth century British jurist A.V. Dicey was inspired by this evolution when he commented that the Habeas Corpus Acts "declare no principle and define no rights, but they are for practical purposes worth a hundred constitutional articles guaranteeing individual liberty." Dicey delivered a series of lectures at Oxford which were first published in 1885 under the title, Introduction of the Study of the Law of the Constitution, ${ }^{97}$ with the aim to introduce students to "two or three guiding principles" of the constitution. Foremost, among these guiding principles was "the rule of law," an expression introduced in English law by W.E. Hearn in 1867. The treatise written by Dicey is remarkably clear, and represents the first strictly legal approach to English public law which, up to then, had been dominated by historical studies. The treatise expressed the general doctrine of the rule of law in the form of several detailed statements describing the English constitution. Some of these derived from authors who immediately preceded Dicey. ${ }^{98}$ Dicey gave three meanings to the rule of law:

First, the rule of law means the absolute supremacy or predominance of regular law as opposed to the influence of arbitrary power, and excludes the existence of

96. See Emilio Santoro, The Rule of Law and the "Liberties of the English": The Interpretation of Albert Venn Dicey, in The Rule of LAW, supra note 6, at 153, 153-58; see also E.P. Thompson, Whigs and Hunters: The Origin of THe Black ACt 258-69 (1st ed. 1975).

97. Albert Venn Dicey, Introduction to the Study of the Law of the Constitution 187 (10th ed. 1982) (1889).

98. See H.W. Arndt, The Origins of Dicey's Concept of the "Rule of Law," 31 AustL. L.J. 117 (1957). 
arbitrariness; a man may with us be punished for a breach of law, but he can be punished for nothing else. ${ }^{99}$

Thus, according to this first meaning, nobody could be made to suffer penalties except for a distinct breach of law established before the ordinary courts. According to Dicey, the systems under the rule of law differed from the systems of government based on the exercise of wide arbitrary powers of constraint by those in authority, such as the power of detention without trial. Secondly, the rule of law ensured "equality before the law, or the equal subjection of all classes to the ordinary law of the land administered by the ordinary law courts" which meant that nobody was above the law and that there were no administrative courts. ${ }^{100}$ Thirdly, the rule of law signified:

\footnotetext{
that with us the law of the constitution, the rules which in foreign countries naturally form part of a constitutional code, are not the source but the consequence of the rights of individuals, as defined and enforced by the courts; that, in short, the principles of private law have with us been by the action of the courts and Parliament so extended as to determine the position of the Crown and of its servants; thus the constitution is the result of the ordinary law of the land. ${ }^{101}$
}

Thus, according to its third meaning, the rights of the individual were secured, not by guarantees set down in a formal document, as in the constitutions of European states, but by the ordinary remedies of private law available against those who unlawfully interfered with his liberty, regardless of whether they were private citizens or public officials. According to Dicey, the rule of law was linked to another fundamental constitutional principle, the principle of parliamentary sovereignty; a principle which made superfluous in England a written constitution modelled on those of the European continent. The principle of parliamentary sovereignty implies that Parliament has the right to make or abolish any law and that no organ or individual in Great Britain has the right to ignore parliamentary legislation. In considering that the Parliament is a sovereign holder of an absolute legal power, the political sovereignty thus remains with the electorate.

Dicey follows the late nineteenth century legal philosopher John Austin who maintained that, in order to exist as such, a state required a sovereign body whose competence was not predefined and whose power could not be

99. Id.

100. $I d$.

101. DiCEY, supra note 97, at 202-03. 
limited. ${ }^{102}$ This conception of parliamentary sovereignty rules out the division, adopted by jurists on the continent, between constitutional or fundamental laws and ordinary laws. This is why the English constitution does not contain a catalogue of fundamental or unalterable rights, the rights of Englishmen "being safeguarded by the common law" which ensured personal liberty as guaranteed by the habeas corpus writs, freedom of assembly, freedom of speech, freedom of debate, and "by ordinary courts." In addition, the sovereignty of the Parliament is incompatible with the existence of a constitutional charter defining the competence of every authority like those of continental Europe. Its legitimacy depends on the respect of the historic "rights of Englishmen." Thus, according to Dicey, on the one hand, there is the legislative sovereignty of parliament or the King in Parliament as a formal legal source. On the other hand, there is a common law in the hands of ordinary courts as a natural legal source which applies the laws adopted by the Parliament, while following an autonomous jurisprudential tradition bound only by legal precedent.

Half a century after Dicey, Friedrich von Hayek developed the ideas of Dicey in The Road to Serfdom in which Hayek identified the rule of law as the core of British liberty and established a connection between "the growth of a measure of arbitrary administrative coercion and the progressive destruction of the cherished foundation of British liberty, the rule of law." ${ }^{103} \mathrm{He}$ juxtaposed (1) the English spontaneous legal order, which developed naturally through history and was founded on tradition and case-law, in which political institutions are merely instrumental; (2) the legal orders founded on the artificial construct of the Rechtsstaat or continental states, and (3) the legal orders of the totalitarian states where institutions were central for the operation of the rule of law. ${ }^{104}$ According to Hayek, only the English legal order genuinely ensures a notion of the rule of law based on liberty, allowing individuals to know the range of activities in which they are completely free to do as they please without being exposed to government coercion. Hayek reiterates:

[T] he government in all its actions is bound by rules fixed and announced beforehand - rules which may be possible to foresee with fair certainty how the authority will use its coercive powers in given circumstances and to plan one's

102. Id. at 26-27; see also Santoro, supra note 96.

103. F.A. HAYeK, The RoAd to SERfDOM xxi-xxv (50th Anniversary ed. 1994) (1944).

104. See generally F.A. Hayek, The Constitution of Liberty (1960). 
individual affairs on the basis of this knowledge. The goals of substantive equality and distributive justice are inconsistent with the rule of law. ${ }^{105}$

The ideas of Hayek have been highly influential in the United States, in particular, where economic liberalism has had its way. ${ }^{106}$

Thus, the originality of the English rule of law has been linked by Dicey and Hayek to the originality of the English constitution. In England, the different nature of powers does not result from any imperative act by the state or from the general will of a constituent assembly expressing popular sovereignty, nor does it result from a written and normatively supreme constitutional charter like in the United States. In England, the Parliament can change the constitution at any time and no political body is entrusted with controlling the constitutionality of legislative acts. The English constitution depends on a longstanding tradition rooted in political conflicts between the King and Parliament and between the absolutist demands of monarchs and the courts as guarantors of English freedoms, normative acts, customs, usages, and not strictly legal precepts. In some cases these conflicts are centuries old and "are tied to a millenial and immemorial ancient constitution" whose validity derives from its own "antiquity" and from its quality of being the "law of the land." Thus, the rule of law is only very indirectly a legal theory of the state; it is not its "juridicisation" or "constitutionalisation." The English rule of law contrasts with the German or French notions of "legislative state" according to which judges are officials of the state who have to apply the law of the state and individual rights are only those laid down by the Parliament. Indeed, the English rule of law is "a distinctive characteristic of the English constitution." 107

In present day Britain the meanings of the rule of law proposed by Dicey and Hayek have been said to "raise considerable problems." ${ }^{108}$ With regard to the supremacy of the law, the first meaning of rule of law proposed by Dicey discussed above, the emphasis on the attacks against the existence of

105. HAYEK, supra note 103 , at 80.

106. F.A. Hayek, The Political Ideal of the Rule of Law 34 (1955). For a critique, see Maria Chiara Pievatolo, Leoni's and Hayek's Critique of the Rule of Law in Continental Europe, in THE RulE OF LAW, supra note 6, at 421, 421 (pointing out that the juxtaposition suggested by Hayek mirrors the classic opposition between a government of law and a government of man devised by Plato in his Statesman).

107. Danilo Zolo, The Rule of Law: A Critical Reappraisal, in The Rule of Law, supra note 6, at 9,9 1997).

108. See A.W. Bradley \& K.D. Ewing, Constitutional and Administrative Law 105 (12th ed. 
discretionary powers has been displaced in favour of the establishment of a system of legal and political safeguards by which the exercise of discretionary powers may be controlled. ${ }^{109}$ The second meaning of the rule of law given by Dicey relating to the equal subjection of all persons to the ordinary law is similar to that of the Fourteenth Amendment to the United States Constitution, which provides, inter alia, that no state shall "deny to any person within its jurisdiction the equal protection of the laws." 110 It is also similar to the provisions laid down in the constitutions of India, Germany, and Canada. ${ }^{111}$ But today, any legal system, including the English system, distinguishes between different categories of persons by reference to economic or social considerations or their legal status. Furthermore, although Dicey proclaimed the illegitimacy of administrative law in Britain, ${ }^{112}$ today it is accepted in Britain that the legal protection of the citizens against unlawful official conduct can be secured by separate administrative courts. Finally, today it is difficult to share Dicey's faith in the common law.

[A]s the primary legal means of protecting the citizen's liberties against the state. ${ }^{113}$ In the first place, the common law is subject to modification by Parliament: the most fundamental liberties may be removed by statute. Secondly, the common law does not assure the citizen's economic or social wellbeing. Thirdly, while it remains essential that legal remedies are effective, the experience of many Western countries is that there can be value in imposing legal limits upon the legislature's power to infringe human rights: and the European Convention on Human Rights has shown the value of supra-national remedies. ${ }^{114}$

109. See Kenneth Culp Davis, Discretionary Justice: A Preliminary Inquiry (Greenwood Press Reprt. 1980) (1969). See also Kenneth Culp Davis et Al., Discretionary Justice in Europe And America (1976). Cf. Committee on Administrative Tribunals and Enquiries, Report of the Franks Committee, 1957, Cmnd. 218, $₫ 29$ (U.K.).

110. U.S. Const. amend. XIV $\S 1$. This provision has been a fertile source of constitutional challenges to discriminatory state legislation in Canada. See Geoffrey Marshall, Constitutional Theory (1980); P.G. Polyviou, The Equal Protection of the Laws (1980).

111. See K. Tuori, The Rule of Law and the Rechtsstaat, in Ratio and Voluritas, Chap. 7 , 8 et seq. (Ashgate 2011); Canadian Charter of Rights and Freedoms, Part 1 of the Constitution Act, 1982, being Schedule B to the Canada Act, c.11, 115 (U.K.); Grundgesetz für Die BundersRepubliK Deutschland [Grundgesetz] [GG] [Basic Law], May 23, 1949, BGBl. 1, art. 3 (Ger.); India Const. art. 14.

112. See L. Neville Brown \& John S. Bell, French Administrative Law (Clarendon Press, 5th ed. 1998) (1967).

113. DiCEY, supra note 97, at 199 (for practical purposes worth a hundred constitutional articles guaranteeing individual liberty).

114. See E.C.S. Wade, G. Godfrey Phillips \& A.W. Bradley, Constitutional and Administrative LAW 102 (9th ed. 1977). It has been suggested that currently, the UK rule of law expressed three related but separate ideas:

First the rule of law expresses a preference for law and order within a community rather than 
Therefore, it can be argued that Dicey's view of the rule of law is based on an analysis of the British constitution which today is in many respects outdated. Nor did Dicey adequately resolve the potential conflict between the two notions of the rule of law and the supremacy of Parliament or indeed the Royal Prerogative. ${ }^{115}$ For, unlike most European states and the United States, legal limits on the sovereignty of Parliament have not been imposed in the United Kingdom and there is no judicial review of Acts of Parliament. ${ }^{116}$ Indeed, the term "judicial review" has been "expropriated by administrative law" "17 to refer exclusively to review of the acts of the executive, a government minister, or a local authority where it is alleged that they have acted unlawfully. The expression "judicial review" has been mostly used as a technical term to denote the application to the court for a remedy against such unlawful administrative action. However, important constitutional innovations have been incorporated into British constitutional arrangements recently. First, the adoption of the Human Rights Act 1998 has introduced two important changes into UK law. On the one hand, it has incorporated into English law most of the rights provided for by the European Convention on Human Rights and its First and Sixth Protocols. These rights, termed "Convention Rights," are laid down in a Schedule to the Act. The Act, makes explicit in Section 6(1) that "[i]t is unlawful for a public authority to act in a way which is incompatible with a Convention right." On the other hand, the Human Rights Act contains a series of solutions for possible conflicts between fundamental rights and the sovereignty of Parliament, e.g., by requiring UK courts to construe all legislation, both primary and secondary, consistently with Convention rights and requiring the UK courts to make a declaration of

anarchy, warfare and strife. In this sense, the rule of law is a philosophical view of society that is linked with basic democratic notions. Secondly, the rule of law expresses a legal doctrine of fundamental importance, namely that government must be conducted according to law, and that in disputed cases what the law requires is declared by judicial decision. Thirdly, the rule of law should provide in matters both of substance (for example, whether the government should have power to detain citizens without trial) and of procedure (for example, the presumption of innocence in criminal trials, and the independence of the judiciary).

A.W. BRADLEY \& K.D. EWING, supra note 92.

115. The Royal Prerogative is the body of customary authority, privilege and immunity belonging to the Sovereign. The Prerogative covers several important powers in the field of the Constitution, the Administration, the conduct of foreign affairs, defence and national security which by convention are not in many cases exercised by the monarch herself but mostly by the government.

116. See generally N.W. Barber, The Rechtsstaat and the Rule of Law, 53 U. ToronTo L.J. 443 (2003).

117. JACOBS, supra note 1 , at 7 . 
incompatibility upon which the Government can take remedial action for an Act of Parliament to be amended. ${ }^{118}$ Secondly, the Constitutional Reform Act of 2005 has severed the link between the judiciary and the House of Lords through the establishment of the Supreme Court of the United Kingdom, operative since October 2009. The consequence of this is that the UK is evolving towards an incipient constitutional separation between legislative and judicial powers. Indeed, the UK's membership of the European Union has had the effect of "Europeanising" the way in which English courts interpret and apply English law by looking more to the aim and purposes of legislation rather than to the literal meaning and by being more ready to apply general principles, such as the principles of proportionality and human rights. To some extent, English courts are following the "European way" of the rule of law, ${ }^{119}$ which accepts judicial review by supranational institutions. Thus, most recently Lord Tom Bingham has proposed a "core" definition of the rule of law ("that all persons and authorities within the state, whether public or private, should be bound by and entitled to the benefit of law publicly made, taking effect (generally) in the future and publicly administered in the courts" which he expands to over the protection of human rights and compliance by the state with its obligations in international law as well as in national law. ${ }^{120}$

\section{(iv) The supranational pan-European concept}

This "European way" of the rule of law derives from the law of the European Union and from the system established under the European Convention of Human Rights.

\section{(a) The Rule of Law in the European Union}

As we have seen, historical legal differences between European States in the attribution of sovereignty, constitutional mechanisms, and the protection of individual rights explain the different doctrines and expressions of the rule of law in those states. However, when the philosophical and political assumptions behind such diversities are considered, they give way to a great number of similar legal institutions and political structures which provide a

118. Id. at $25-38$.

119. Bulmer v. Bollinger, [1974] Ch. 401 at 425 (Eng.); see also JACOBS, supra note 1, at 12.

120. This evolution meets some of the concerns expressed by Lord Bingham in Lord Bingham, The Rule of Law, 66 CAmbridge L.J. 67 (2007). See Lord T. Bingham, The Rule of Law 8 et seq. (Allen Lane Penguin 2010). 
basis for a genuine pan-European rule of law acceptable to all European states. Indeed, any European national legal system is entrusted with the task of protecting individual rights and any legal system has enacted provisions constraining the inclination of political power to expand, to act arbitrarily, and to abuse its prerogatives ${ }^{121}$ by means of the "principle of distribution of powers." The limitation of the power of the state aims at enlarging the scope of individual freedoms, differentiates the legal system from non-legal subsystems (ethical, religious or economic), and delimits the function of the legislator or legis latio and the enforcement of legislation or legis executio ${ }^{122}$ or the "principle of differentiation."

These common European elements have made it possible to refer to the rule of law as a common European value of the European Union in the new Article 2 of the Treaty on European Union (TEU) (as amended by the Treaty of Lisbon) which provides that:

$[\mathrm{T}]$ he Union is founded on the values of respect for human dignity, freedom, democracy, equality, the rule of law and respect for human rights, including the rights of persons belonging to minorities. These values are common to the member states in a society in which pluralism, non discrimination, tolerance, justice, solidarity and equality between women and men prevail. ${ }^{123}$

When looking at the French, Spanish, Italian or German versions of the treaties, it is interesting to note that the term rule of law has been translated by Etat de droit, Estado de Derecho, Stato di Diritto, or Rechtsstaat, as equivalent legal notions so that the inclusion of the element of statehood has no effect for the purpose of the "supranational" EU conception of the rule of law. ${ }^{124}$

Indeed there is an EU supranational concept of the rule of law that appears to be the most important principle promoting unity both of the law of the European Union and of political integration of the European Union. This EU rule of law has been described as "a constitutional principle" of the

121. Zolo, supra note 107 , at 19.

122. N. Luhmann, Gesellschaftliche und politische Bedingungen des Rechtsstaates, in STUDIEN ÜBER Recht Und Verwaltung 53-65 (Köln 1967).

123. Quoted in Laurent Pech, The Rule of Law as a Constitutional Principle of the European Union; Jean Monnet Working Paper Series No. 4/2009, 20 (2009), available at http://ssrn.com/abstract=1463242.

124. See, e.g., R. Bin, Lo Stato di diritto (I'l Mulino ed., 2004); Armin von Bogdandy, Founding Principles, in 8 Principles of European Constitutional LaW 3, 28 (Armin von Bogdandy \& Jürgen Bas eds., 2006). For a criticism of a perceived lack of uniform employment of the concept of the rule of law in EU institutions and policies, see E. WenNerström, The Rule of LAW AND the European Union 348 (Iuitus Förlag 2007). 
European Union. ${ }^{125}$ According to the EU rule of law, the European Union itself and its institutions operate under the law. Indeed, in its seminal judgment Parti écologiste Les Verts, the Court of Justice of the European Union, was first to define the European Union, not as a "state governed by law" or simply on the rule of law, but as a "Community based on the rule of law." The Court emphasized in this regard that:

[T] he European . . . [Community] is a [Community] based on the rule of law, inasmuch as neither its Member States nor its institutions can avoid a review of the question whether the measures adopted by them are in conformity with the basic constitutional charter, the Treaty. In particular ... the Treaty established a complete system of legal remedies and procedures designed to permit the Court of Justice to review the legality of measures adopted by the institution. ${ }^{126}$

In its Opinion of 1991, the Court of Justice reaffirmed the political and legal nature of the European Union, recalling that the founding treaty was "the constitutional charter of a community based on the rule of law" which established a new legal order:

[I]ndeed[,] the ... treaty aims [at] . . making concrete progress towards European unity ... [the] Treaty albeit concluded in the form of an international agreement, nonetheless constitutes the constitutional charter of a Community based on the rule of law. The . . . treaties established a new legal order for the benefit of which the states have limited their sovereign rights in ever wider fields and the subjects of which comprise not only Member States but also their nationals. The essential characteristics of the ... legal order which has thus been established are in particular its primacy over the law of the Member States and the direct effect of a whole series of provisions. ${ }^{127}$

The formula "Community based on the rule of law" is actually the translation of the German term Rechtsgemeinschaft, formulated for the first time by Walter Hallstein, President of the European Commission from 1958

125. Pech, supra note 123 , at 1 .

126. Case 294/83, Parti ecologiste "Les Verts" v. Parliament, 1986 E.C.R. 1339, 1365.

127. Opinion 1/91, Opinion Pursuant to Article 228 of the EEC Treaty, 1991 E.C.R. 6079, 6102. It is to be noted that in the Lisbon Treaty Ratification Judgment of 30 June 2009, the German Constitutional Court (Bundesverfassungsgericht) appears to indicate that further steps towards European unity may require an amendment of some of the fundamental provisions of the German Fundamental Law. See Helmut Phillip Aust, German Constitutional Law Cases 2007-2009, 16 Eur. Public Law, Mar. 2010, at 17, 36; Jacques Ziller, The German Constitutional Court's Friendliness towards European Law: On the Judgment of Bundesverfassungsgericht over the Ratification of the Treaty of Lisbon, EuR. PuBlic LAw, Mar. 2010, at 53 (suggesting that the German Constitutional Court appears to indicate that further steps towards European unity may require an amendment of some of the fundamental provisions of the German Fundamental Law). 
to $1967,{ }^{128}$ which in French is translated as Communauté de droit. The Court of Justice avoided using the classical term Rechtsstaat or Etat de droit in order to escape the difficulty of characterising the European Union as a "State." However since the Maastricht Treaty of 1992, the Amsterdam Treaty of 1997, and the Nice Treaty of 2003, new developments have taken place. For, even though the European Union is nowhere defined as a "Community based on the rule of law," the treaties have subsequently expressly provided that the European Union is based on the principle of the rule of law, presently in Art. 2 TEU (Lisbon).

The reviewability of decisions of public authorities by independent courts is key to the EU notion of the rule of law, and this demonstrates that the European Union is based on the rule of law to a far greater extent than any other international or transnational organization or entity. ${ }^{129}$ The European Union is endowed with a Court of Justice, and the Court of Justice has held that:

[A]ccess to justice is one of the constitutive elements of a Community based on the
rule of law and is guaranteed in the legal order based on the Treaty in that that the
Treaty has established a complete system of legal remedies and procedures designed
to permit the Court of Justice to review the legality of measures adopted by the
institutions ... the Court of Justice uses the constitutional traditions common to the
Member States and ... the European Convention For the Protection of Human
Rights and Fundamental Freedoms as a basis for the right to obtain an effective
remedy before a competent court.

The jurisdiction of the Court is not optional but compulsory. The main purpose of the Court is to ensure that "in the interpretation and application of the Treaties the law is observed." (Art. 19 of the (Lisbon) TEU). Additionally, the Court functions to underscore the importance that, in measures taken by the European Union institutions, "in a community governed by the rule of law, adherence to legality must be properly ensured." 131 This guarentees that the Courts considerable powers are exercised in accordance with the law and that Member States comply with adverse judgments when they fail to observe their

128. M. Zuleeg, Die Europäische Gemeinschaft als Rechtsgemeinschaft, NEUE JURISTISCHE Wochenschrift 546 (1994) (quoting Walter Hallstein, Die Europäische Gemeinschaft 51 (Dusseldorf: Econ-Verlag 1979).

129. JACOBS, supra note 1 , at 35.

130. See Case C-131/03, R.J. Reynolds Tobacco Holdings, Inc. v. Comm'n, 2006 E.C.R. I-7795, 7837 (quoting and later affirming a proposition from the Court of First Instance in the judgment on appeal).

131. Case C-496/99, Comm'n v. CAS Succhi di Frutta SpA, 2004 E.C.R. I-3801, 3870. On the several aspects of the impact of the Treaty of Lisbon, see W. Twining \& D. Miers, How to Do Things with Rules (Law in Context) 315 et seq. (5th ed. Cambridge Univ. Press 2010). 
duties under the European Union Treaties. Indeed, if a Member State fails to comply with a judgment of the Court, that Member State is liable to have a very substantial fine imposed. ${ }^{132}$ Thus, the European Union's rule of law is applicable both to the European Union institutions and to the Member States. This is illustrated by the fact that, "the Treaty has established the Court of Justice as the judicial body responsible for ensuring that both the Member States and the Community institutions comply with the law." ${ }^{133}$ As it has been pointed out, "there is no precedent or equivalent in international law for this system of enforcement." ${ }^{34}$ Finally, the Court of Justice of the European Union adjudicates on questions of Union law referred to it by the court of a Member State. This mechanism has allowed the Court to develop a remarkable body of case-law, including a body of administrative law which seeks to strike an appropriate balance between the public authorities and the individual:

\footnotetext{
Individuals are ... entitled to effective judicial protection of the rights they derive from the Community legal order, and the right to such protection is one of the general principles of law stemming from the constitutional traditions common to the Member States. That right has also been enshrined in Articles 6 and 13 of the European Convention for the Protection of Human Rights. ${ }^{135}$
}

This has even inspired substantial and positive developments in the purely internal law of the Member States. ${ }^{136}$ The most important principle derived from the EU rule of law is that of effectiveness or effet utile of law with regard to public authorities and includes the legal concepts of autonomy and direct effect of Union law, primacy and comprehensive legal protection.

The concept of autonomy and direct effect was laid down for the first time in the celebrated judgment of van Gend en Loos in 1963. ${ }^{137}$ That case dealt with the question, referred to the Court, of whether a specific treaty provision could be enforced in the national courts in the face of conflicting national legislation. The Court held that the "Community" or Union constituted a new legal order of international law for the benefit of which the

132. For an examination of the record of compliance of the Member States, see Phedon Nicolaides \& Anne-Marie Suren, The Rule of Law in the EU: What the Numbers Say, 2007 EIPAScope, No. 1, 33.

133. Case C-2/88, Zwartveld, 1990 E.C.R. I-3365, 3372.

134. JACOBS, supra note 1 , at 36.

135. Case C-229/05, Ocalan ex rel. Kurdistan Workers' Party v. Council, 2007 E.C.R. I-439, 508.

136. See generally Koen Lenaerts, The Rule of Law and the Coherence of the Judicial System of the European Union, 44 Common MKт. L. Rev. 1625, 1645-50 (Aug. 2007)(discussing the obligations placed on the national courts of Member States by European Union law).

137. See Case 26/62, Van Gend \& Loos v. Nederlandse administratie der belastingen, 1963 E.C.R. 1. 
states had limited their sovereign rights and the subject of which comprised not only the Member States but also their nationals. This meant that the Treaty created individual rights which the national court must protect: "the task assigned to the Court of Justice under Article (234) ... confirms that the states have acknowledged that [Community] law has an authority which can be invoked by the nationals before those courts and tribunals." ${ }^{, 138}$ It has been pointed out that the ruling is decisive both to the effectiveness of Union law and to the very existence of the rule of law:

[F]irstly because it meant that individuals could secure recognition and enforcement of their Union rights in the national courts, secondly because it made national courts the principal instrument for effective application of Union law, and thirdly, because it led to the recognition of the primacy of Union law over national law; if Union law were to be applied by the national courts, it had to be applied across the Union as a whole, leaving no room for the idea that the application of Union law might conflict, in some Member States, with national law; Union law must necessarily prevail over national law, and this was indeed inherent in the very idea of a Union based on the rule of law. ${ }^{139}$

The concept of primacy or supremacy of Union law derives from the inherent logic of the Union system. It was spelled out in the Costa v. ENEL judgment which stressed the unique character of the principle of primacy in the Treaty since, "in contrast with ordinary treaties, the treaty has created its own legal system which, on entry into force of the treaty, became an integral part of the legal system of the Member States and which the courts are bound to apply." 140 This means that Union law, "of whatever status, prevails over conflicting national law of whatever status." 141 This concept applies not only to Treaty provisions but to decisions, ${ }^{142}$ directives, ${ }^{143}$ and other legal acts. ${ }^{144}$ The concept of supremacy of Union law has in the past been challenged by the constitutional courts of Germany, ${ }^{145}$ Italy, ${ }^{146}$ and by the Supreme Court of

138. Id. at 12 .

139. JACOBS, supra note 1 , at 40.

140. Case 6/64, Costa v. ENEL, 1964 E.C.R. 585, 593.

141. JACOBS, supra note 1 , at 41.

142. Case 9/70, Grad v. Finanzamt Traunstein, 1970 E.C.R. 826.

143. Case 8/81, Becker v. Finanzamt Münster-Innenstadt, 1982 E.C.R. 53.

144. Case 181/73, Haegeman v. Belgian State, 1974 E.C.R. 449.

145. See Bundesverwaltungsgericht [BVerwG] [Federal Constitutional Court] The Solange I [BverfGE] 37, 271; Bundesverwaltungsgericht [BVerwG] [Federal Constitutional Court] The Solange II [BverfGE] 73, 339; Bundesverwaltungsgericht [BVerwG] [Federal Constitutional Court] The Maastricht Ratification Judgment [BverfGE] 1993, 89; Bundesverwaltungsgericht [BVerwG] [Federal Constitutional Court] The Lisbon Treaty Ratification Judgment [2 BvE] 2/08.

146. See Frontini v. Ministerio delle Finance, case 183, Corte Costituzionale (Italy) (Racc. uff. corte 
Denmark. ${ }^{147}$ However, the Court of Justice has established that the principle of primacy cannot be denied in stating:

$[\mathrm{N}] \mathrm{o}$ provision of municipal law; of whatever nature they may be, may prevail over Community law ... lest it be deprived of its character as Community law and its very legal foundations be endangered. The validity of a Community act or its application in a Member State remains, therefore, unimpaired even if it is alleged that the basic rights ... of the national constitution were violated. ${ }^{148}$

This is so even when it seems legally and constitutionally impossible for the laws of some Member States. ${ }^{149}$ This is so even with regard to international law in cases where a United Nations Resolution of the Security Council, acting under Chapter VII of the UN Charter, or an international agreement is incompatible with the law of the European Union. The Court of Justice has held that:

[I]n a Union based on the rule of law, ] an international agreement cannot affect the allocation of powers fixed by the treaties or, consequently, the autonomy of the Community legal system, observance of which is ensured by the Court by virtue of the exclusive jurisdiction conferred on it by Article 220, jurisdiction that forms part of the very foundations [of the Union]. ${ }^{150}$

In addition, the Court of Justice acknowledged that where the Union judicature decides that a Union measure, intended to give effect to a UNSC resolution under Charter VII, is contrary to "a higher rule of law in the Community legal order" it would not entail any challenge to the primacy of that resolution in international law. ${ }^{151}$

cost. 1973); (1974) CMLR 372.

147. See Maastricht Ratification Judgment (UfR 1998).

148. Case 11/70, Internationale Handelsgesellschaft $\mathrm{mbH}$ v. Einfuhr und Vorratsstelle fur Getreide und Futtermittel, 1970 E.C.R. 1125, 1134.

149. See Regina v. Sec'y of State for Transp. ex parte Factortame Ltd., [1991] 1 A.C. 603 (H.L.). In particular with regard to the doctrine of parliamentary sovereignty of the UK (according to which no Parliament can bind its successor). The primacy of Union law in relation to a future Act of Parliament was considered in the UK courts in the Factortame cases (see Regina v. Sec'y of State for Emp't ex parte Equal Opportunity Comm'n, [1995] 1 A.C. 1 (H.L.)), where the House of Lords held, as the court of final appeal and after reference to the Court of Justice of the European Union, that the law of the European Union prevailed over the act of Parliament. Thus where an act of Parliament of the UK is clearly incompatible with Union law, the British court will disapply the provisions of the Act without a reference to the Court of Justice of the European Union. See JACOBS, supra note 1, at 42.

150. Joined Cases C-402/05 and C-415/05, Kadi v. Council, 2008 E.C.R. I-6351, 6490.

151. Id. at 6491 . 
The rule of law has also been associated by the Court of Justice of the European Union with the fundamental values referred to in Articles 2 and 6 of the (Lisbon) TEU. In a Union based on the rule of law, "its institutions are subject to judicial review of the compatibility of their acts with the Treaty and with the general principles of law which include fundamental rights." 152 In particular, Article 6 of the Treaty provides that the Union recognizes the rights, freedoms, and principles set out in the Charter of the Fundamental Rights of the European Union of December 7, 2000. It also provides that it "shall have the same value as the Treaties," 153 that the Union shall accede to the European Convention for the Protection of Human Rights and Fundamental Freedoms, and that fundamental rights shall exist as guaranteed by the European Convention. As they result from the constitutional traditions common to the Member States, the same articles guarantee that they "shall constitute general principles of Union's law." Thus, the Court has held that access to justice is "one of the constitutive elements of a community based on the rule of law" and it uses the constitutional traditions common to the Member States and Articles 6 and 13 of the European Convention for the Protection of Human Rights and Fundamental Freedoms "as a basis for the right to obtain an effective remedy before a competent court." "154

The Court of Justice has derived a great number of principles from the above-mentioned core concepts of the rule of law. These include the concept of legal certainty (otherwise referred to as legal clarity and predictability), ${ }^{155}$ the protection of fundamental rights, ${ }^{156}$ such as procedural rules governing actions brought before the Union's courts ensuring effective judicial protection of an individual's rights under Union law), ${ }^{157}$ and the principle of democracy. ${ }^{158}$ The Court also developed from these core concepts the principles of due process, ${ }^{159}$ justice, ${ }^{160}$ state liability under Union law, ${ }^{161}$ the

152. Case C-50/00, Union de Pequenos Agricultores v. Council, 2002 E.C.R. I-6677, para. 38.

153. Treaty of Lisbon Amending the Treaty on European Union and the Treaty Establishing the European Communities, Dec. 13, 2007, 2007 O.J. (C 306) 1.

154. See Case C-131/03, R.J. Reynolds Tobacco Holdings, Inc. v. Comm'n, 2006 E.C.R. I-7795, 7837 (quoting and later affirming a proposition from the Court of First Instance in the judgment on appeal). 155. See Case 10/78, Belbouab v. Bundesknappschaft, 1978 E.C.R. 1915, 1924.

156. See Case 11/70, Internationale Handelsgesellschaft $\mathrm{mbH}$ v. Einfuhr und Vorratsstelle fur Getreide und Futtermittel, 1970 E.C.R. 1125, 1134.

157. See Case C-521/06, Athinaiki Techniki AE v. Comm'n, 2008 E.C.R. I-5829, 5879; Henry G. Schermers \& Denis F. Waelbroeck, Judicial Protection in the European Union 309-19 (6th ed. Kluwer Law Int'1 2001).

158. See Case 138/79, SA Roquette Freres v. Council, 1980 E.C.R. 3333, 3360.

159. See Case 248/84, Federal Republic of Germany v. Comm'n, 1987 E.C.R. 4013, 4042.

160. Joined Cases $17 \&$ 20/61, Klöckner-Werke AG \& Hoesch AG v. High Auth. of the European 
principle of solidarity, ${ }^{162}$ and the principle of equality. ${ }^{163}$ Furthermore, it gained the principle of proportionality, i.e. the principle that EU institutions may only impose such obligations, restrictions, and penalties upon citizens as are strictly necessary for the attainment of the aims pursued for purposes of the public interest. ${ }^{164}$ These principles, including the principle of sound administration, are fundamental to good governance. ${ }^{165}$ The Court additionally developed the protection of legitimate expectations, ${ }^{166}$ the principle of transparency, ${ }^{167}$ and the right of access for the citizen to official documents. ${ }^{168}$ Finally, it obtained fundamental values such as religious freedom, ${ }^{169}$ the principle of equal treatment,${ }^{170}$ the right to respect for private life, ${ }^{171}$ and the principles relating to the internal market of the Union: fiscal supervision, ${ }^{172}$ public health, ${ }^{173}$ fairness of commercial transactions, ${ }^{174}$ defence of the consumer,${ }^{175}$ freedom to trade,,${ }^{176}$ fair competition,,${ }^{177}$ and the protection of the environment. ${ }^{178}$

These are all principles that form part of the European civil law system and the European common law system. ${ }^{179}$ Both systems have been reinforced by the impact of the law of the European Union upon the domestic law of the

Coal and Steel Cmty., 1962 E.C.R. 325, 340

161. Joined Cases C-6/90 \& C-9/90, Francovich and Others v. Italian Republic, 1991 E.C.R. I-5357, 5414.

162. Joined Cases 6 \& 11/69, Comm'n v. France, 1969 E.C.R. 523, 540.

163. See Case 1/72, Frilli v. Belgium, 1972 E.C.R. 457.

164. Case 11/70, Internationale Handelsgesellschaft $\mathrm{mbH}$ v. Einfuhr und Vorratsstelle für Getreide und Futtermittel, 1970 E.C.R. 1125, 1136

165. See Case 179/82, Lucchini Siderurgica SpA v. Comm'n, 1983 E.C.R. 3083.

166. Cases 205-215/82, Deutsche Milchkontor GmbH v. Germany, 1983 E.C.R. 2633, 2668.

167. See Case T-194/94, Carvel v. Council, 1995 E.C.R. II-2765.

168. Id.

169. Case 130/75, Prais v. Council, 1976 E.C.R. 1589, 1597-98.

170. Joined Cases $117 / 76$ \& 16/77, Albert Ruckdeschel \& Co. v. Hauptzollamt Hamburg-St. Annen, 1977 E.C.R. 1753, 1769.

171. See Case 136/79, National Panasonic (UK) Ltd. v. Comm'n, 1980 E.C.R. 2033.

172. Case 120/78, Rewe-Zentral AGv. Bundesmonopolverwaltung für Branntwein, 1979 E.C.R. 649, 662.

173. Joined Cases 266 \& 267/87, The Queen v. Royal Pharm. Soc'y of Great Britain ex parte Ass'n of Pharm. Imps., 1989 E.C.R. I-1295, 1328.

174. Rewe-Zentral, 1979 E.C.R. at 662.

175. $I d$.

176. See Joined Cases C-37/02 \& C-38/02, Di Lenardo Adriano Srl \& Dilexport Srl v. Ministero del Commercio con l'Estero, 2004 E.C.R. I-6911.

177. See Case C-450/06, Varec SA v. Belgium, 2008 E.C.R. I-581.

178. See Joined Cases C-154/04 \& C-155/04, The Queen v. Sec'y of State for Health \& Nat'l Assembly for Wales, 2005 E.C.R. I-6451; Case C-41/02, Comm'n v. Netherlands, 2004 E.C.R. I-11375.

179. Takis Tridimas, General Principles of EU Law 5-7 ( $2 \mathrm{~d}$ ed. 2006). 
Member States. For instance, judicial remedies constitute a very sophisticated part of the English private law (e.g., the system of injunctions), but remedies in public law have been weak until recently. In particular, injunctions against ministers of the crown were not allowed under English law, but since the Factortame litigation and following a reference to the Court of Justice of the European Union, the House of Lords held that an injunction should be granted under English public law. ${ }^{180}$

Finally, as it has been pointed out, the European Union based on the rule of law serves "as a magnet" for other European states to join it. ${ }^{181}$ Additionally, further beyond its frontiers, the Union has inspired many imitations. ${ }^{182}$

In addition to the EU rule of law, there is the pan-European system created by the European Convention for the Protection of Human Rights and Fundamental Freedoms which covers a wider European space than the system of the European Union.

180. See Regina v. Sec'y of State for Transp. ex parte Factortame Ltd., [1991] 1 A.C. 603 (H.L.).

181. JACOBS, supra note 1, at 122 (2007). Indeed, the European Union has expanded ever since 1973, when the original Union of six became a Union of nine (first enlargement), then a Union of twelve (second and third enlargements of 1981 and 1986), then a Union of fifteen (fourth enlargement of 1995), and now a Union of twenty-seven (fifth and sixth enlargements of 2004 and 2007). Id. It should be noted that following the entry into force of the Treaty of Lisbon, actually even before then ever since the adoption of the Copenhagen criteria, respect for the rule of law constitutes a condition for accession to the Union (The Copenhagen criteria are requirements defining whether a European state is eligible to join the European Union. They include geographic, political (democracy, rule of law, human rights and respect for and protection of minorities), economic criteria (free market economy) and legislative alignment to the law of the Union. They were adopted by the European Council of Copenhagen in 1993). ERIK O. WenNerström, The Rule of LaW and the European Union 35 (2007). Indeed, enlargement of the European Union cannot take place unless the newcomers comply with the rule of law as one of the fundamental European values laid down in Article 2 of the (Lisbon) TEU: Article 49 of the (Lisbon) TEU provides that "Any European state which respects the values referred to in Article 2 and is committed to promoting them may apply to become a member of the Union." Treaty of Lisbon amending the Treaty on European Union and the Treaty Establishing the European Community, art. 49, Dec. 13, 2007, 2007 O.J. (C 306) 1.

182. JAСОВS, supra note 1 , at 130 . "The Union has been seen as a model," the progressive integration of economies in other regions of the world being a salient feature in recent years: the North American Free Trade Agreement (NAFTA), the Association of Southeast Asian Nations (ASEAN), the Southern American Common Market (MERCOSUR), the Andean Pact, and several African groupings including Southern Africa (SADEC), East and Southern Africa (COMESA), and West Africa (ECOWAS), together with the attempt which has now been made to form a continent-wide African Union directly imitating the European Union, as well as the Commonwealth of Independent States (comprising the eleven former Soviet Republics of Armenia, Azerbaijan, Belarus, Georgia, Kazakhstan, Kyrgyzstan, Moldova, Russia, Tajikistan, Ukraine and Uzbekistan, with Turkmenistan being an associate member), and finally the Conference on Security and Cooperation in Europe which adopted the 1990 Paris Charter for a new Europe which announced " $a$ new area of democracy, peace and unity' founded upon 'human rights, democracy and the rule of law." Id. 
(b) The Rule of Law under the European Convention for the Protection of Human Rights

The European Convention for the Protection of Human Rights and Fundamental Freedoms (1950), generally known as the European Convention on Human Rights, was elaborated and adopted under the auspices of the Council of Europe. Article 3 of the Statute of the Council of Europe provides that every Member state of the Council of Europe "must accept the principles of the rule of law and of the enjoyment by all persons within its jurisdiction of human rights and fundamental freedoms." ${ }^{183}$ Articles 7 and 8 of the Statute provide for suspension and, where a Member state of the Council of Europe seriously violates Article 3, for appropriate expulsion from the Council of Europe. These provisions have no parallel in the history of international organizations.

The rights protected by the Convention include most of the basic civil and political rights, such as: the right to life, liberty and security; prohibition of torture and of inhuman or degrading treatment, slavery, servitude and forced labor; the right to a fair trial; and freedom of conscience and religion, of speech and of assembly. ${ }^{184}$ These rights are also protected by the Universal Declaration of Human Rights. The difference between the UN Universal Declaration and the European Convention is that the former is a mere declaratory text while the latter contains a system of judicial enforcement for the human rights protected.

Initially, the enforcement system established in the European Convention consisted of a European Commission of Human Rights and, at a later stage, also a European Court of Human Rights. This enforcement system was subject to voluntary options by states. Now, because of the Eleventh Protocol of November 1, 1998, which merged the European Commission of Human Rights and the Court of Human Rights, the European Court of Human Rights has become the only enforcement mechanism provided for by the Convention.

183. In the preamble to the Statute of the Council of Europe, May 5, 1949, E.T.S. 1, the contracting states "reaffirm[ed] their devotion to the spiritual and moral values which are the common heritage of their peoples and the true source of individual freedom, political liberty and the rule of law, principles which form the basis of all genuine democracy."

184. Convention for the Protection of Human Rights and Fundamental Freedoms arts. 2-6, 9, 11, Nov. 4, 1950, E.T.S. 5. Further rights were added in subsequent protocols to the Convention including property rights and the right to education. The first protocol also requires states to organise free elections, thus establishing a direct link between human rights and democracy. See id. Protocol No. 1 arts. 1-3, Mar. 20, 1952, E.T.S. 9. 
This has resulted in individual applicants being given the right of action before the Court. In addition, the mechanism is not subject to any condition. Accession to the Convention automatically entails permanent acceptance of the jurisdiction of the Court of Human Rights. Furthermore, the parties to a case must abide by the judgments of the Court and take all necessary measures to comply with them. The Committee of Ministers of the Council of Europe supervises the execution of judgments. The Secretary General of the Council of Europe may request the parties to provide explanations on the manner in which their domestic law ensures effective implementation of the Convention.

Acceptance of the Convention is also a precondition for membership of the European Union (Articles 49 and 2 TEU) ${ }^{185}$ which is itself firmly based on respect for the rule of law and respect for human rights. It has also become part of the internal law of many of the Member States, both by virtue of the interpretation of national constitutions by the national courts of the parties or by specific domestic legislation as in the case of the UK Human Rights Act 1998. It has thereby been given internal legal effect in almost all the Member states of the Council of Europe. These internal effects, which enable the Convention to be invoked in domestic courts, have obvious advantages. ${ }^{186}$ Indeed, "the Convention has proven extraordinarily effective [and] it is particularly striking that these developments have taken place in Europe, where state sovereignty has had the longest history, and might have been thought to be most strongly entrenched." The human rights directly related to the rule of law include the right of access to justice, the right to a legally competent judge, inadmissibility of double jeopardy (ue bis in idem), nonretroactivity, presumption of innocence, and the right to a fair trial. ${ }^{187}$

185. Treaty of Lisbon Amending the Treaty on European Union and the Treaty Establishing the European Communities art. 49, Dec. 13, 2007, 2007 O.J. (C 306) 1. It should be noted that ever since the adoption of the Copenhagen Criteria, respect for the rule of law has constituted a condition for accession to the European Union. The Copenhagen Criteria are requirements defining whether a state is eligible to join the European Union. They include geographic, political (democracy, rule of law, human rights, and respect for and protection of minorities), economic (free market economy), and legislative alignment to the law of the European Union. They were adopted by the European Council of Copenhagen in 1993. See Presidency Conclusions, Copenhagen European Council (June 21-22, 1993).

186. For a summary of the effects of the Convention in UK law as a result of the UK Human Rights Acts 1998, see JACOBS, supra note 1, at 23-34.

187. See Report on the Rule of Law Venice Communication Council of Europe, CDL-AD 003, para. 59, at 12 (2011). See also Rule of Law Inventory Report, Hague Institute for the Internationalization of Law Discussion Paper for the High Level Expert Meeting on the Rule of Law of 20 Apr. 2007, at 16. JACOBS, supra note 1 , at $22-23$. 
(c) Assessment: The Added Value of the Pan-European Rule of Law

The two European systems described above have contributed remarkably to reinforce the rule of law within Europe. Indeed, the two European systems provide an additional supranational remedy to those existing under the domestic law either where there is no domestic remedy or in the absence of domestic jurisdictions. The new additional supranational remedy is for the benefit of individuals and corporations and can be exercised before the EU supranational courts where supranational institutions act illegally, e.g., the review of the legality of EU acts as laid down in Article 263 TFEU. ${ }^{188}$ In addition, where there is no remedy available within the domestic system, the two European systems can improve the domestic systems by requiring them to establish a new national remedy. On the one hand, the European Court of Human Rights held that Article 6, paragraph 1 of the Convention, which provides that everyone is entitled to a fair and public hearing within a reasonable time by an independent and impartial tribunal, guarantees a right of access to a court and consequently, that English law had to provide for such remedy.

$[\mathrm{O}]$ ne can scarcely conceive of the rule of law without there being a possibility of access to a court ... the principle whereby a civil claim must be capable of being submitted to a judge ranks as one of the universally recognised fundamental principles of law; the same is true of . . . international law which forbids the denial of justice; Article 6, para. 1 must be read in the light of these principles. ${ }^{189}$

On the other hand, the Court of Justice of the European Union has recognized the right to judicial protection as a general principle of law that must be ensured by national law. ${ }^{190}$ Finally, the European systems of protection of the rule of law have established a very beneficial "dialogue" between both the Court of Justice of the European Union and the European Court of Human Rights and the national courts. ${ }^{191}$ This dialogue has resulted in a marked improvement of all the systems involved. ${ }^{192}$ With the accession

188. Id. at 14 .

189. Golder v. United Kingdom, 1 Eur. H.R. Rep. 524, para. 34 (1975); id.

190. Case 222/86, Union Nationale des Entraîneurs et Cadres Techniques Professionnels du Football (UNECTEF) v. Heylens, 1987 E.C.R. 4097, 4117.

191. JACOBS, supra note 1, at 14.

192. For a detailed examination of this mutual beneficial influence and dialogue, see Ricardo Gosalbo-Bono, The Development of General Principles of Law at National and Community Level: Achieving a Balance, in RichterReCht UND RECHTSFORTBILDUNG IN DER EUROPÄISCHEN Rechstgemeinschaft 99 (2003); E. CARparro, Etat de Droit ET Droits Européens (L'harmattan 
of the European Union to the system of the European Convention of Human Rights foreseen in Article 6 of the TEU, a more persistent dialogue between the two supranational courts should result in an even more sophisticated and uniform system of protection of the rule of law for the whole Europe.

The question arises as to how this European concept compares with other legal systems. Among those systems, that of the United States awakens curiosity because of its proximity to European legal systems. Thus, the question is, whether there is a unified conception of the rule of law shared between Europe and the United States.

\section{The Rule of Law in American Law}

Following the philosophical and political thoughts of John Locke and Thomas Jefferson, the law of the United States incorporates the most radical principles of individualism and liberty ever known to man. These principles, proclaimed in the American Declaration of Independence, were inserted in the Preamble of the U.S. Constitution and provide that people have certain fundamental and inherent rights such as life, liberty, property ownership, and the pursuit of happiness. These rights have been endowed by "nature and God," and not by government.

\section{(i) The Natural Rights of Man}

Liberty and natural rights explain why the rule of law has acquired a central position in U.S. law to the point where the rule of law has become a "veritable civil religion." 193 Indeed, the liberty of citizens and their individual natural rights could not be secured unless the act of self-determination embodied in the most fundamental law of the land, i.e. the Constitution, limited the power of the government. ${ }^{194}$ Thus, the U.S. Constitution purports above all to institute a government which can be kept within a very narrow remit: to protect, and not regulate or destroy, the natural rights of the people bestowed by God. ${ }^{195}$ On the one hand, the constitutional doctrine of

2005).

193. Brunella Casalini, Popular Sovereignty, the Rule of Law, and the "Rule of Judges" in the United States, in The Rule of Law, supra note 6, at 201, 201.

194. On the origins and intentions of the framers of the Constitution, see generally FORREST McDonald, Novus Ordo Seclorum: The Intellectual Origins of the Constitution (1985); Jack N. Rakove, Original Meanings: Politics and Ideas in the Making of the Constitution (1996).

195. Jacob G. Hornberger, The Constitution and the Rule of Law, Freedom Daily, Aug. 1992, at 1, 2. For a general treatment of the subject see generally Ronald A. CASs, THE Rule of LAw In AMERICA 
legislative, executive, and judicial separation of powers, the checks and balances of each branch against the others, and the explicit guarantees of individual liberty, were all designed to strike a balance between authority and liberty, which is the main objective of the U.S. Constitution. On the other hand, the laws of the United States, and international treaties ratified by the United States, became "the supreme law of the land" pursuant to Article VI of the Constitution and ordinary laws, even those made by the legislature, were to be subject to the fundamental law of the Constitution and could, therefore, be held invalid if they violated it.

If laws which conflict with the Constitution may be held invalid, the question then of course, becomes who can declare the laws invalid. The U.S. Constitution does not provide an answer. That answer was provided by the U.S. Supreme Court. While replying on the principle of separation of powers, the U.S. Supreme Court held that it had power to review the compatibility of ordinary legislation with the Constitution, i.e. judicial review. The constitutional judicial review was established by the U.S. Supreme Court, specifically by Chief Justice Marshall, in the famous case of Marbury $v$. Madison in 1803. ${ }^{196}$ In that case, the Supreme Court found a conflict between a statute enacted by the U.S. Congress and the Constitution. The Court noted that Article III of the U.S. Constitution provides, that the judicial power is exercised by the courts, that the Constitution is interpreted by the courts, and that the Supreme Court of the United States is the final court of appeal from the state and federal courts. The Supreme Court then held that it had the authority to render null and void any federal or state law that was contrary to the fundamental law of the U.S. Constitution. The Supreme Court considered that "the essence of judicial duty" was to ensure that the law conforms to the Constitution and this principle constitutes the essence of the American understanding of the rule of law.

Although the expression rule of law does not appear in the Constitution, a close constitutional analogy has been found in the "due process" clauses of the Fifth Amendment ("No person shall be . . . deprived of life, liberty or property without due process of law") and Fourteenth Amendment ("Nor shall any state deprive any person of life, liberty or property, without due process of law"). ${ }^{197}$

214 (John Hopkins Univ. Press 2003).

196. Marbury v. Madison, 5 U.S. (1 Cranch) 137, 137 (1803).

197. R. Charlow, America's Constitutional Rule of Law, in Comparative Perspective, supra note 11, at 89, 89; George P. Fletcher, Basic Concepts of Legal Thought 13 (Oxford Univ. Press 1996). 
(ii) Due Process under the Fifth Amendment

With regard to the Fifth Amendment, the Supreme Court has held that it is:

[A] settled doctrine of this Court that the Due Process Clause embodies a system of rights based on moral principles so deeply embedded in the traditions and feelings of our people as to be deemed fundamental to a civilized society as conceived by our whole history. Due process is that which comports with the deepest notions of what is fair and right and just. ${ }^{198}$

Indeed, the content of due process of law under the Fifth Amendment is "a historical product" $" 199$ whose meaning originates in chapter 39 of Magna Carta, in which the English King John promised that:

$[\mathrm{N}]$ o free man shall be taken or imprisoned or disseized or exiled or in any way destroyed, nor will we go upon him nor send upon him, except for the lawful judgment of his pairs or by the law of the land $[.]^{200}$

Due Process also has roots in the English Liberty of Subject Act of 1354, according to which "no man of what state or condition he be, shall be put out of his lands or tenements nor taken nor disherited, nor put to death, without he be brought to answer by due process of law." ${ }^{201}$ Over time, the expression "due process of law" became widely used until the founders of the American constitutional system incorporated it into the U.S. Constitution. The constitutional meaning of the expression "due process of law" was taken from the work of Sir Edward Coke. In his Second Institutes, Coke identified the term "by the law of the land" with the term "due process of law," which he in turn defined as "by due process of the common law," that is "by the indictment or presentment of good and lawful men . . or by writ original of the Common Law." 202 In the early years of the United States, the terms "law of the land" and "due process" were used somewhat interchangeably. Initially, the term "law of the land" was the preferred expression in colonial charters and declarations of rights, but some state constitutions incorporated both

198. SolesBee v. Balkcom, 339 U.S. 9, 16 (1950). Due process is violated if a practice of rule "offends some principle of justice so routed in the traditions and conscience of our people as to be ranked fundamental." Snyder v. Massachusetts, 291 U.S. 97, 105 (1934).

199. Jackman v. Rosenbaum Co., 260 U.S. 22, 31 (1922).

200. William Sharp McKechnie, Magna Carta 375 (Burt Franklin 1914) (1905).

201. English Liberty of Subject Act, 1354, 50 Edw. III, c.3.

202. CoKe, supra note 94 , at 50. 
terms. ${ }^{203}$ Later, "due process of law" became the favorite and soon the question arose whether due process of law was a principle relating to procedure or whether it also included questions of substance. ${ }^{204}$

While a literal interpretation of the language used in the Fifth Amendment leads to the conclusion that it is a procedural provision, as it appears to refer to court procedure, that is not the interpretation that has been given to the due process of law by the U.S. Supreme Court. On the one hand, the Supreme Court held that the legislature or Congress was not free to determine the contents of due process in stating that:

[I]t is manifest that it was not left to the legislative power to enact any process which might be devised. The article is a restraint on the legislative as well as on the executive and judicial power of the government, and cannot be so construed as to leave congress free to make any process "due process of law" by its mere will. ${ }^{205}$

On the other hand, the Supreme Court held that due process under the Fifth Amendment also incorporates the protection of substantive rights for historical reasons. Early in the judicial history of the United States, a number of jurists attempted to formulate a theory of natural rights or natural justice that would limit the power of government, especially with regard to property rights. They argued firstly, that the written constitution was the supreme law of the state and that judicial review could only apply to legislation and not to

203. The 1776 Constitution of Maryland, for example, used the language of the English Magna Carta including the expression "law of the land." In New York a statutory bill of rights was enacted in 1987 containing four different clauses relating to "due process." Alexander Hamilton commented on the language of the bills of rights of New York that "the words 'due process' have a precise technical import." Alexander Hamilton, Remarks on an Act for Regulating Elections, in 5 The Founders' Constitution 313, 313 (Philip B. Kurland \& Ralph Lerner eds., Univ. of Chicago Press 1987). New York was the only state that asked Congress to enact the language relating to due process in the Constitution of the United States with the following proposal: "no person ought to be taken in prison or disseized of his freehold, or be exiled or deprived of his privileges, Franchises, Life, Liberty or Property, but by due Process of Law." James Madison drafted his proposal for a clause on due process based on the New York proposal by cutting some language from it and inserting the word "without" which had not been proposed by New York. Congress then adopted the exact wording that Madison proposed aware that the due process clause would not be sufficient to protect guarantees of the right "although I know whenever the great rights, the trial by jury, freedom of the press, or liberty of consciences, come in question in that body (Congress) the invasion of them is resisted by able advocates, yet there Magna Carta does not contain anyone provision for the security of those rights, respecting which the people of America are most alarmed." Congress, Amendments to the Constitution, in 128 The Founders' Constitution 313, 313 (Philip B. Kurland \& Ralph Lerner eds., Univ. of Chicago Press 1987); John V. Orth, Due Process of Law: A Brief History 30-31 (Univ. Press of Kansas 2003).

204. ORTH, supra note 203.

205. Murray's Lessee v. Hoboken Land and Improvement Co., 59 U.S. 272, 276 (1856). 
the "unwritten law" or "natural rights." Secondly, they argued that the "police power" of government enabled the legislature to regulate the use and possession of property in the public interest, subject only to the specific prohibitions in the written Constitution. These jurists thus found in the "law of the land" and the "due process of law" clauses of the state constitutions provided substantive restrictions on the power of the legislature. ${ }^{206}$ Indeed, Chief Justice Roger B. Taney was not innovating when, in his opinion in the Dred Scott case, he commented on one of the reasons why the Missouri Compromise $^{207}$ was unconstitutional:

[The Act of Congress which deprived] a citizen of his liberty or property, merely because he came himself or brought his property into a particular territory of the United States, and who had committed no offense against the laws, could hardly be dignified with the name of due process of law. ${ }^{208}$

Thus at present, the due process clause of the Fifth Amendment offers a procedural and substantive protection to all persons within the territory of United States, including not only citizens, but corporations, aliens, and presumptive citizens seeking readmission to the United States. The Fifth Amendment does not apply to the U.S. States.

\section{(iii) The Due Process under the Fourteenth Amendment}

Instead, U.S. States are subject to the due process of law clause inserted in the Fourteenth Amendment, which was adopted following the American Civil War. Under the Fourteenth Amendment:

$[\mathrm{N}] \mathrm{o}$ state shall make or enforce any law which shall abridge the privileges and immunities of citizens of the United States; nor shall any state deprive any person of life, liberty or property, without due process of law; nor deny to any person within its jurisdiction the equal protection of the laws.

Again, due process under the Fourteenth Amendment can be divided into two categories: procedural due process and substantive due process. Procedural due process is based on principles of "fundamental fairness" and deals with procedures that must apply in state proceedings, such as: giving

206. Edward Samual Corwin, Liberty Against Government 59-115 (Louisiana State Univ. Press 1948).

207. The 1820 agreement between the pro-slavery and the anti-slavery factions of Congress, involving the regulation of slavery in the Western territories.

208. Scott v. Sanford, 60 U.S. 393, 450 (1857). 
notice, an opportunity for a hearing, confrontation and close examination, discovery, the basis for the decision, and availability of counsel. Substantive due process is used to assess whether the substance of a law can fairly be applied by states at all, regardless of the procedure followed for its adoption. Substantive due process has generally dealt with specific subjects, such as: liberty of contract or privacy. Over time, emphasis has been placed on the importance of economic and non-economic matters. Although, in theory, procedural and substantive due process are closely related, in practice, substantive due process has had greater impact because significant portions of the legislative jurisdiction of a state can be restricted by its application.

This is so because the due process clause under the Fourteenth Amendment has been used to make a large portion of the Bill of Rights applicable to States. This resulted from the adoption between 1865 and 1870 following the Civil War of the so-called Reconstruction Amendments (13th, 14 th and 15th) to the U.S. Constitution in order to change the "half-slave and half-free," in the words of President Lincoln, nature of the United States, into a unified land of freedom for the whole population. These amendments gave the federal courts the authority to apply the Bill of Rights when a State threatened any fundamental right of its citizens. ${ }^{209}$ Over time, the principal provisions of the Bill of Rights have been held applicable to the three protections of the Fourteenth Amendment, i.e. privileges and immunities, due process, and equal protection. ${ }^{210}$ In particular, a gradual "absorption" into due process of the rights provided for in the Bill of Rights has taken place by means of the doctrine of "selective incorporation" 211 which has made possible the incorporation into the due process clause of personal rights, ${ }^{212}$ freedom of speech and the press, ${ }^{213}$ liberty, ${ }^{214}$ the prohibition of unreasonable searches and seizures $^{215}$ and, not without some controversy, the legalization of abortion. ${ }^{216}$

209. Akhil Reed Amar, The Bill of Rights: Creation and Reconstruction 163-80 (Yale Univ. Press 1998).

210. See Charles Fairman, Does the Fourteenth Amendment Incorporate the Bill of Rights?, 2 STAN. L. Rev. 5, 5-6 (1949); Howard Jay Graham, Our Declaratory Fourteenth Amendment, 7 Stan. L. Rev. 3, 3-39 (1954). For the evolution of the case-law, see Walter Walker v. Sauvinet, 92 U.S. 90 (1876); Spies v. Illinois, 123 U.S. 131 (1887).

211. Felix Frankfurter, Memorandum on "Incorporation" of the Bill of Rights Into the Due Process Clause of the Fourteenth Amendment, 78 Harv. L. Rev. 746, 747-48 (1965).

212. Twining v. New Jersey, 211 U.S. 78, 99 (1908).

213. Gitlow v. New York, 268 U.S. 652, 666 (1925).

214. NAACP v. Alabama, 357 U.S. 449, 460 (1958).

215. Abington Sch. Dist. v. Schempp, 374 U.S. 203, 215 (1963).

216. Roe v. Wade, 410 U.S. 113, 113 (1973). 
The principal controversy today is whether, once a guarantee or a right set out in the Bill of Rights is held to be a limitation on the States under due process of law, the same standard which restricts the action of the federal government restricts that of the States. The majority of the Supreme Court has consistently held that the standards are identical, irrespective of whether the Federal Government or a State is involved. ${ }^{217}$ " [T] $]$ o suppose that due process of law meant one thing in the fifth amendment and another in the fourteenth is too frivolous to require elaborate rejection." ${ }^{18}$ The Court has also rejected "the notion that the Fourteenth Amendment applies to the state only as a watered down, subjective version of the individual guarantees of the Bill of Rights." 219 Those who have argued for a differentiated application of due process for the federal government and for the States, (in the past Justices Harlan, Steward, Fortas, Powell, and Rehnquist) have stated that, if the same standards were to apply, the standards applied to the federal government would have to be diluted when applied to the States in order to give the States more flexibility in the operation of their systems of criminal justice. ${ }^{220}$ The latter result seems to have been reached for the purpose of application of the jury trial guarantee of the Sixth Amendment. ${ }^{221}$

\section{(iv) The Supreme Court as the guarantor of the American Rule of Law}

It is important to note that within the context of the rule of law, the United States has put in the hands of its courts, not in its legislature or in its executive, many of the fundamental choices that society makes. American courts, and in particular the Supreme Court, have become the ultimate arbiter in conflicts between goals and values. This has required not merely that American courts apply the law in force, but also that they develop the law. In the process of the development of the law, the question of the reasoning employed in judicial decisions has become of major importance. It is often asked if the courts seek to determine the "original intent" of the constitution and to give effect to that. The U.S. Supreme Court held in 1855, that in order to determine whether a process is "due process" the first step is to "examine the Constitution itself, to see whether this process be in conflict with any of

217. Malloy v. Hogan, 378 U.S. 1, 10-11 (1964).

218. Malinski v. New York, 324 U.S. 401, 415 (1945).

219. Williams v. Florida, 399 U.S. 78, 107 (1970).

220. Williams v. Florida, 399 U.S. 78, 129-38 (1970).

221. See Steven Breyer, Active Liberty: Interpreting Our Democratic Constitution 50 (Alfred A. Knopf 2005). 
its provisions." ${ }^{222}$ Others believe that the courts should treat the constitution rather as an evolving instrument, to be adapted to changing circumstances and to changing values. In that case, judicial review may include criteria which balances "the importance of the governmental interest being served and the appropriateness of the governmental method of implementation against the resulting infringement of individual rights," with two consequences. First, if the governmental action breaches a fundamental right, the highest level of judicial review or "strict scrutiny" is applied. ${ }^{223}$ Additionally, in order to pass the review of "strict scrutiny," the law or act must lay down very clearly that it pursues "a compelling interest of the government."

When the governmental action or law restricts liberty in a manner that does not affect a fundamental right, then the judicial review is exercised on a "rational basis" and the existence of a legitimate interest of the government is sufficient for it to pass the review. ${ }^{224}$ Recently, a perceived erosion of the rule of law in the United States, particularly with regard to actions taken by the Bush Administration, ${ }^{225}$ has led to renewed debates over the role of American courts as final guarantors of the rule of law. ${ }^{226}$

Above all, American law has given birth to what is considered to be the "essence of constitutionalism," i.e. the idea of a rule of law, according to which the Constitution is the fundamental law which entitles the courts to set aside even the laws enacted by democratic legislatures which violate the constitution. Judicial review of the constitutionality of legislation has a dual

222. Murray v. Hoboken Land, 59 U.S. 272, 277 (1855). On the power of the American judiciary see R. Fass, The Rule of Law in America 214 (Johns Hopkins Univ. Press 2003).

223. Adarand Constructors v. Pena, 515 U.S. 200, 200-39 (1995).

224. Sanford H. Kadish, Methodology and Criteria in Due Process Adjudication-A Survey and Criticism, 66 Yale L.J. 319, 319-63 (1957).

225. See Jerry L. Mashaw, Due Processes of Governance: Terror, the Rule of Law, and Limits of Institutional Design, 22 Governance: An International Journal of Policy, Administration, and InSTITUTIONS 353, 353-68 (2009).

226. The movement of critical legal studies has attacked the idea of a rule of law openly stressing the ideological character of judicial deliberations. However, various contemporary approaches defend the idea of the rule of law through the formulation of theories of interpretation aimed at providing judicial decisions with objective foundations. The main theories are the following: those that identify the rule of law as the rule of rules (i.e., as a formal "state under the law") in which judges respect the objective meaning of the text of the law and avoid interpreting the intention of the legislator (the rule of men) in order to avoid judicial arbitrariness (see Antonin Scalia, The Rule of Law as a Law of Rules, 56 U. CHI. L. REv. 1175-88 (1989)); those that identify the rule of law with the objective principles of constitutional morality informing the constitution (see Ronald Dworkin, Freedom's Law: The Moral Reading of the American Constitution 7-12 (1996)); and those that identify the rule of law with the commitment of the people to self-government and to the reformulation of fundamental rights (see BRUCE Ackerman, We The People (1991); Bruce Ackerman, We the People: Transformations (1998)). See also Cass, supra note 195, at 72; Casalini, supra note 193, at 214-16. 
justification in the United States. Firstly, since the Constitution is the supreme law of the land, its principles prevail over ordinary legislation. Secondly, since in the United States federal powers are divided between the U.S. Congress and the State legislatures, each being the supreme legislature, the separate legislatures are equal, and there is no true sovereign. In that situation, there is a need for an independent system of adjudication with powers to resolve disputes over the respective competences of the central legislature and the state legislatures.

It results from the preceding analysis that the American idea of the rule of law shares the following principles with the European Union: (i) power may not be exercised arbitrarily; (ii) the law is supreme and independent; (iii) equality of the law; and (iv) respect for individual rights. The question arises as to how the European and American conceptions of the rule of law compare with other expressions of the rule of law resulting from the different legal systems and regions in the world. A brief examination of this question is provided in the following paragraphs.

\section{The Rule of Law in China and the Rest of Asia}

The old Chinese civilization was governed by the rule of man and by the rule by law. The rule of man originated in the Confucian philosophy and in the body of "rules of proper behaviour," called $l i$, which prevailed in old Chinese law. It corresponded to a genuine "rule by rite." ${ }^{227}$ In the Confucian Chinese view, social relations were part of the natural order and must, in compliance with the Confucian and Tung Chung-Shu doctrines, conform to cosmic harmony: man and God, Heaven and Earth, all things living and inert, are organic parts of a harmoniously ordered and integrated universe. Therefore, the most important goal of man must be to keep his thoughts, feelings, and actions in perfect accordance with cosmic harmony. The ideal man is a person who is conscious of the natural order of the world and who recognizes the necessity of the rules of behaviour, follows them spontaneously and modestly, and quietly represses his own interests in order to maintain that harmony. Above all, man must comply with the $l i$, or rules of proper behaviour specifically dependent on the social status of the person concerned and on the specific situation. Law could not take into account of all the various imponderables inherent in the social position of the parties and court

227. Wu Shu-chen, Chinese Legal Tradition and the European View of the Rule of Law, in THE RULE OF LAW, supra note 6, at 615, 618. 
procedures could not be established to uphold legal rights based on these complicated structures. This led to skepticism about the value of law and all forms of court enforcement; a tradition that survives in the China of today. Any breach of the rules of $l i$ must be resolved by finding an equitable solution by means of peaceful discussions, by exercising a degree of forbearance in a conflict and, if necessary, by accepting injustice. Therefore, since law played only a complementary role to morality and $l i$, traditional China developed a great variety of forms of conflict resolution outside the courts (e.g., conciliations by the head of the family or by a relative in family disputes). This meant that only a very small proportion of disputes (mainly relating to matters of private law) were submitted to state courts for resolution.

In contrast to the Confucian school of thought, there existed the old Chinese legalist school of thought which criticized the Confucian system as nothing more than "rule of man," or ren zhi, in which the Confucian sage determined what was best in a given situation based on his own judgment rather than on legal rules of general applicability. In response, the legalists advocated the rule by law, or $f a z h i$, according to which laws had to be written, clearly codified, publicly promulgated, and impartially applied to commoner and nobleman alike. However, under the $f a$ zhi of the legalist school, the ruler remained the ultimate authority, both in theory and in practice, and the scope of his discretion was only limited by his own morality and his understanding of social expectations. Law was what pleased the ruler, who retained the power to enact and amend the laws and remained above and beyond the law. ${ }^{228}$ Law was simply a pragmatic instrument for obtaining and maintaining political control and social order.

Later, the Chinese Imperial legal system combined the Confucian rule by rite and the legalist rule by law, however the system reflected the inherent weaknesses of both. These shortcomings led to a reform movement at the end of the Qing dynasty. However, the successive reforms of the dynasty never succeeded in reversing the shortcomings. This situation prevailed until very recently.

In the early 1900s, a number of reformers advocated learning from the West and specifically from Western legal systems and the notions of rule of law, i.e. constitutionalism and human rights. They imported European legal traditions which led to an improvement of the Chinese legal system. These changes included the elaboration of the first Chinese constitution in the early

228. Randall Peerenboom, Competing Conceptions of Rule of Law in China, in AsIAN Discourses OF RULE OF LAW, supra note 49, at 100, 111. 
1900s, the adoption of legal codes modelled on German and Japanese laws, and the modernization of the judiciary and the restructuring of the courts. These modern judiciary incorporated the establishment of administrative courts, professional judges, and a bar of private practitioners. However, such reforms did not succeed in the turbulent, republican period that preceded Communism. During the socialist or communist period, the legal systems served primarily the interests of politicians. As in earlier periods, the law was conceived of as an instrument to strengthen a paternalistic state. That is, the purpose of law was to serve the state, not to protect individual rights. There was little if any separation between law and politics. There was neither an independent judiciary nor an autonomous legal profession. There were no effective limits on state power, particularly the power of the ruler and the ruling elite. There were few legal remedies available to the citizens in order to challenge government decisions. Finally, there was little space for the participation of ordinary citizens in the elaboration, enactment, or implementation of legislation. ${ }^{229}$

Since the death of Mao in 1976, China has undertaken unprecedented economic, political, and legal reforms. Within this framework, the drive to implement the rule of law has received wide support from various groups. For the new rulers of China, many of whom suffered under the arbitrary rule of Mao, the dangers of unfettered government are readily apparent and the desire for legitimacy, both at home and abroad, has made possible a discussion about how to hold the government accountable for its actions. Since 1999, the Chinese constitution provides that China "implements [the principle] to rule the country according to law" or "yi la zhi guo" and establishes "a socialist state regulated by law" or "jianshe shehuizhuyi fa zhi guoja." Fa zhi has become, above all, an expression of extensive legislation by the National People's Congress and the State Council, China's central government. In particular, administrative law is seen as a way to rationalize governance, enhance administrative efficiency, and control local governments. Owing to a political system controlled by a paramount "leading party" and the absence of separation of powers, $f a z h i$ is an instrument for political ends rather than a principle limiting political power. However, as economic reforms have progressed, people have begun to have more property and business interests to protect and this has increased the demand for greater protection of their rights and interests. ${ }^{230}$ At present, one of the main theoretical and practical

229. See generally Randall Peerenboom, China's Long March Toward Rule of Law (2002). 230. Article 90 of the Law on Legislation of the People's Republic of China lays down a procedure 
issues relating to the rule of law is how to reconcile the leading role of the Chinese Communist Party with the principle of the supremacy of law, which is a basic tenet of the rule of law. ${ }^{231}$

The rest of Asia does not offer a unified picture on the rule of law. While the rule of law, in its European and American conceptions, forms an integral part of the mature Japanese democracy, ${ }^{232}$ the rule of law is the subject of political debate in Hong Kong, Singapore, Malaysia, and even Vietnam. In contrast, until very recently, the term rule of law remained largely irrelevant to most Koreans. Thailand, after decades of semi-democracy followed by repeated coups, adopted a new constitution in 1997 that incorporated the rule of law. Yet, democracy and human rights attract more attention than the rule of law because the Thai term for the rule of law is Luck Nititham, implying a precept of law based upon a sense of justice and virtue. The term "justice" in Thailand is steeped in popular incomprehension because it is not an easy notion to grasp in a concrete sense. For that reason there is a kind of mythification of the term as a lynchpin of Thai society. Thus, the rule of law has become a "rule of lore," ${ }^{233}$ a myth without practical impact. In Vietnam, like in China, the main issue is whether the ruling regime is willing to accept the basic requirement of the rule of law and whether the state and state actors are bound by the law. ${ }^{234}$

There have been attempts to postpone the implementation of the requirements of the rule of law in Asia because the idea is not part of the "Asian values." The term "Asian values" was first proposed by the Prime Minister of Singapore, Mr. Lee Kuan Yew, in order to give priority to economic developments, the improvement of living standards, and the secondary priorities of non-interference in the internal affairs of the state over civil and political rights. The concept of "Asian values" has attracted strong

for constitutional review of legislation. LifaFa [Law on Legislation], 2000 Standing Comm. NAT'L People's Cong. Gaz. 112 (China). The law ensures political rights but these can be suspended by the National People's Congress. See id. art. 8.

231. According to some authors, there is "ample room for further improvement in China's future constitutional development." Ling Feng, Modern Constitutionalism in China, in The Rule of Law, supra note 6, at 633, 643. See also Yali Peng, Democracy and Chinese Political Discourses, 24 Modern China 408-44 (1998); Minxin Pei, Racing Against Time: Institutional Decay and Renewal in China, in ChINA Briefing: The Contradictions of Change 11-49 (William A. Joseph ed., 1997); FAZHi DE LIXIANG YU Xianshi 33 (Gong Xiangui ed., 1993); Su Li, Bianfi, Fazhi Jianshe Ji Gi Bentu Ziyuan, 41 ZhongwaI FAXUE 1 (1995) (emphasizing the native Chinese institutions (bentu ziyuan)).

232. Carl F. Goodman, The Rule of Law in Japan: A Comparative Analysis (2008).

233. Vitit Muntarbhorn, Rule of Law and Aspects of Human Rights in Thailand, in AsIAN Discourses of Rule of LAW, supra note 49, at 340, 348.

234. Id. 
criticism in large part because Asia is not a monolithic culture, but also because Asian Confucian civilization focuses on the moral growth of the individual and not on human rights and democracy. ${ }^{235}$ It is no mere coincidence that the pre-eminence of economic and social values is also a tenet of legal socialism.

\section{The Socialist Rule of Law}

The legal system that resulted from the Soviet revolution of 1917, giving birth to the USSR, and that later inspired other communist states (at present there remains notably China, Vietnam, North Korea, and Cuba), does not accept the subjection of the state to a higher law. This system, based on Marxist-Leninist ideology, creates a totalitarian state which, in order to ensure economic equality, owns all the means of production and lacks a system of protection of private civil rights. It does not ensure the principle of separation of powers and it does not provide for judicial review of action by the government. In this system, the law is an instrument used by the state in order to eliminate the political power and dominance of the bourgeoisie and to motivate society towards communism under the supervision of the communist party. In the stage of transformation, which lasts indefinitely, socialist law has evolved to tolerate a socialist legality in which certain individual rights, mainly procedural and statutory, are upheld against the state, provided that such rights do not involve any political or religious rights to oppose the socialist regime. The ultimate control of the legal system lies with the leadership of the communist party, which is the only party authorized within that system. The aim of socialist legality is to ensure legally the good ordering of society in response to social needs. ${ }^{236}$ Thus, the socialist idea of the rule of law is very limited and does not offer guarantees for the supremacy of the law over the will of the communist party or the arbitrary exercise of power by the state. $^{237}$

At the opposite extreme of the socialist legality lies the Islamic religious conception of the rule of law.

235. See A. Ehr-Soon Tay, "Asian Values” and the Rule of Law, in The Rule of LAw, supra note 6 , at $565,575-76$.

236. For a discussion and critique, see Eugene Kamenka \& Alice Erh-Soon Tay, Beyond the French Revolution: Communist Socialism and the Concept of Law, 21 U. Toronto L.J. 109, 132-36 (1971).

237. Laurence Lustgarten, Socialism and the Rule of Law, 15 J.L. Soc'y 25 (1988). See, e.g., Report by the International Commission of Jurists on Cuba and the Rule of Law (Geneva 1962). 


\section{The Rule of Law in Islam}

Islamic Law requires that Muslims first obey Allah (God), through the Prophet Mohamed, who was ordered by God to guide his people or ummah in their life. As such, the Prophet is also a legislator or al-shari, and in turn those who have political authority, provided that their decisions and policies conform to the injunctions of God (via the Koran), and the tradition of the Prophet or Hadith as stipulated in the Koran. Consequently, according to Islamic Law, the ultimate authority and sovereignty does not lie with the political authorities, but with the law of God or Sharia. ${ }^{238}$ The Sharia comprises not what Western lawyers categorize as a set of legal rules; but rather, something deeper and higher, connected with the divine, and infused with moral and metaphysical purpose. That is, a set of unchanging beliefs and principles that order life in accordance with the will of God and the idea that all human beings, and all human governments, are subject to justice under the law of God. ${ }^{239}$ Islamic law obliges its adherents to apply Islamic moral principles to politics and the state. The moral and ethical principles of the Islamic political system consist of trust or amanah, justice or adalah, consultation or shura, pluralism or ta'addudiyyah, ${ }^{240}$ equality or musawah, brotherhood or $u k h u w w a h$, and peace or silm. The Prophet Mohamed himself established the Medinah state in the year 627 by issuing the Medinah Constitution or mithaq al-madinah, which is considered to be the first written constitution in the world. ${ }^{241}$

Thus, the Islamic state is a Rechtsstaat or dawlat al-qanun, subject to the rule of law of the Sharia or siyadat al-qanun. As such, the traditional Islamic state and political system was, for more than a thousand years, a "divine nomocracy" or a "theo-democracy" governed by the Sharia, which did not offer a doctrine of separation of powers. This system rendered a government legitimate only if it generally respected the individual legal rights of its subjects laid down in the Sharia and if it was accepted by those subjects as doing so. ${ }^{242}$ The Sharia individual rights, known as "the rights of humans," included the rights to: life, property, legal process, and individual rights

238. See Edward Mortimer, Faith and Power: The Politics of Islam 16 (1982).

239. See generally Kilian Bälz, Sharia Versus Secular Law, in IsLAm AND the Rule of LAw 121 (Helmut Reifeld \& Birgit Krawietz eds., 2008).

240. See Abdulaziz Sachedina, The Islamic Roots of Democratic Pluralism 15 (2001).

241. See Sayyid Abul A’la Maududi, Islamic Law and Constitution 57-62 (1960).

242. B. Krawietz \& H. Reifeld (Hrsg.), Islam und Rechtistaat ZMO, Konrad Adenauer Stiftung 19-37 (2008); Anthony Black, The History of Islamic Political Thought: From the Prophet to the Present 11 (2001); Patricia Crone, God's Rule: Government and Islam 20 (2004). 
arising from the relationship between individuals and the Islamic state. ${ }^{243}$ Any Islamic ruler, either the caliph or another, was subject to the Islamic rights of humans which functioned as a guarantee against oppression by arbitrary acts of the Islamic government. ${ }^{244}$ The rights of humans contrasted with the "rights of God" which, of course, also formed part of Islamic law. The relationship between God and individual included questions relating to worship and rituals. The Islamic principle, according to which the ruler was subject to the rule of law of the Sharia, or hukm al-qanun, was enforced by Islamic scholars, who became the guardians of Islamic law, and whose pronouncements operated as a real balance to the power of the ruler. Thus, the ruler who perverted the course of justice had to pay the high price of being declared by Islamic scholars in breach of the Sharia - the law of God. Since the Koran does not cover all actions, Islamic scholars had ample latitude to interpret the will of God according to their scholarly consensus or ijtihad. By controlling the law, scholars limited the ability of the political authorities to violate it. ${ }^{245}$ Islamic scholars and their law were absolutely essential to the extraordinary success of Islamic society from its inception until well into the nineteenth century.

Most scholars today accept that modern democracy is compatible with Islamic Law. ${ }^{246}$ Today, Islamic law provides for an Islamic review of legislation by Islamic courts that exercise the functions occupied by Islamic scholars in earlier times. Like the scholars, the judges of the reviewing court present their opinions as interpretations of Islamic law. This is why Muslims

243. Owing to Western prejudice and the horrors of terrorism today, Sharia law has been unfairly and incorrectly portrayed as involving exclusively cruel and unusual penalties such as the amputation of hands and the stoning of adulterers as well as the oppression of, and discrimination against, women. But when the harsh punishments prescribed by the Sharia are assessed by Western commentators, the latter generally fail to acknowledge the high standards of proof that Islamic law requires for the implementation of the punishments. In addition, it is rarely recalled that until the eighteenth century torture was systematically practiced and legally authorised by the criminal laws of most European states and that European married women were denied any property rights or indeed any legal personality independent from that of their husbands until very recently. On the contrary, for most of its history, Islamic law has offered the most liberal and humane legal principles available anywhere in the world. See Adel El Baradie, GottesReCht Und Menschenrecht GrundLAgen der islamischen StrafrechtSLEhre 96 (1983).

244. On the right to resist and the legal debate on rebellion, see Khaled Abou El Fadl, Rebellion AND Violence IN IsLAmic LaW 50 (2d ed. 2002).

245. Timur Kuran, The Rule of Law in Islamic Thought and Practice: A Historical Perspective, in Global Perspectives on The Rule of Law 71 (James J. Heckman et al. eds., 2010).

246. For an overview of the constitutional evolution of Muslim states, see N.J. Brown, Regimes Reinventing Themselves: Constitutional Development in the Arab World, 18 INT'L Soc. 33 (2003); only a small number of Islamic scholars reject modern democracy, arguing that it is a system invented by man and as such negating the sovereignty of God over men. See in this sense H. SALIH, AL-DimuQRATtiYy A Wa-HUKM AL-ISLAM FiHa 95-96 (1988). 
of today are not entirely fanciful when they assert that Sharia can apply in a constitutional state subject to the rule of law. ${ }^{247}$ However, the Islamic rule of law is not equivalent to the Western rule of law. In Western constitutionalism, democracy and the separation of powers presuppose secularism and this is not acceptable to Islamic democracy. This explains why some Islamic democrats view Western democracy as a "doctrine or procedure, a mere method of dispensing, sharing and managing political power and secularism, nationalism and alike." According to these Islamic scholars, secularism is not an inevitable consequence of democracy: free elections, political parties, individual freedoms, and human rights can co-exist within an Islamic constitution which upholds the basic principles of the Islamic faith. ${ }^{248}$

There are other developing countries, mainly in Latin America and Africa, that do not adhere to Islam, and that have undertaken the road to democracy on the Western model.

\section{The Rule of Law in Latin America and Africa}

Since Latin America inherited its civil law systems from Europe, the rule of law is widely considered as an integral part of "democratization." 249 In practice, however, it appears that the transition to democracy in many Latin American countries has proceeded without consolidation of the rule of law. ${ }^{250}$ Citizens and governments alike circumvent the rule of law by pursuing their interests through informal networks and practices. ${ }^{251}$ This "resistance" to or "declining confidence" in the rule of law appears in the available data on the

247. Mawil Izzi Dien, Islamic Law: From Historical Foundations to Contemporary Practice 35-45 (2004).

248. Raji Bahlul, Is Constitutionalism Compatible with Islam?, in The Rule of Law, supra note 6, at 515,515 .

249. For the particular situation of the "native" Americans in respect of the rule of law, see Bartolome Clavero, The Rule of Law and the Legal Treatment of Native Americans, in THE RULE OF LAW, supra note 6 , at 443,456 .

250. Mary Fran T. Malone, An Uneasy Partnership? Democratization and the Rule of Law in Latin America (Aug. 28-31, 2003) (unpublished manuscript) (a paper submitted to the Meeting of the Latin American Political Science Association, Philadelphia); the Economic Freedom of the World Network, Communique on the Rule of Law in Latin America (Nov. 2, 2006) (ranking the region of Latin America as number 85, behind Russia, Senegal and Uganda, in the rule of law).

251. Cf. M. Malone, Citizens' Support for the Rule of Law in Central America (Continuum Pub. 2011). See also E. Peruzzoti \& F. Simulovitz, Enforcing the Rule of Law: Social Accountability in the New Latin American Democracies (Univ. of Pittsburgh Press 2006); R. Bill Chavez, The Rule of Law in Nascent: Democracies (Argentina) 272 (Stanford Univ. Press 2004); Rule of LaW in Latin America: The International Promotion of Judicial Reform (Pilar Domingo \& Rachel Sieder eds., 2001). 
status of judicial independence, military interference, and independence of the law. Chile appears to be the only exception to the declining confidence of Latin America in the rule of law. ${ }^{252}$

Africa has developed its own conceptions of human rights and rule of law over the past decade. ${ }^{253}$ These conceptions have been facilitated by important political transformations, which have given birth to an African view of an international rule of law where priority is given to self-determination, as inspired by the process of decolonization, the definition of the term "refugee," and the insistence, in a continent ravaged by mass murder and poverty, that human rights must protect not only civilian and political rights but also economic and social rights. ${ }^{254}$

The preceding paragraphs provided an illustration of the significance of the rule of law in the different legal systems in the world. The question arises whether it is possible to agree on a definition which could be accepted by all.

\section{Elements for a Universal Definition of the Rule of LAW}

From the preceding analysis, it appears that the Western world emphasizes the independent existence of law as a distinct social phenomenon. The independence of the law, ensured by an independent judiciary, allows effective control of the arbitrary state and guarantees a formal equality of citizens before the law. It also provides legal certainty. In its most general definition, the rule of law expresses the idea that ordinary laws, even those made by the sovereign, are subject to a fundamental law, typically a higher law or constitution, and therefore, can be held invalid by independent courts if that fundamental law is breached. From this general definition two theories on the rule of law have been advocated: formal and substantive. Those who propose a formal theory consider that the rule of law limits itself to requiring only restrictions on the exercise of state authority. They tend to be positivist and are often referred to as "thin theorists." They also consider that the

252. William C. Prillaman, The Judiciary and Democratic Decay in Latin America: Declining Confidence in the Rule of Law 137-52 (2000). See, e.g., Augusto Zimmermann, The Failure of Constitutionalism in Brazil, in Comparative Perspective, supra note 11, at 101, 101; Lisa J. Laplante, The Rule of Law in Transitional Justice: The Fujimori Trial in Peru, in id. at 177, 177.

253. M.M. Mborantino, La CONTRIBUtion DES COURS CONSTITUTIONNELLES À L'ETAT DE DROIT EN AFRIQUe (Economica 2007). For a criticism of the European colonial model of the rule of law in Africa, see Carlos Petit, The Colonial Model of the Rule of Law in Africa: The Example of Guinea, in THE RulE of LAW: History, Theory And Criticism 467-512 (Pietro Costa \& Danilo Zolo eds., 2007).

254. Human Rights, The Rule of Law, and Development in Africa 312 (Paul T. Zeleza \& Phillip J. McConnaughay eds., 2004). 
exercise of power is, with few exceptions, subject to review by courts and that it would ensure that the acts of the public authorities are in conformity with the law. This aspect of the rule of law, known as the principle of legality, includes compliance with the derivative principles of legal certainty, transparency and proportionality, publication, general application, clarity, non-retroactivity of laws, enforceability, and non-discrimination. ${ }^{255}$ Formal theories distinguish themselves from the substantive or "thick theories" according to which the rule of law requires a specific legal content. This content would include values which are widely accepted as essential to modern social and political life, such as the fundamental organizational principles of the state. Examples include, the German Rechtsstaat, the values of the Republican state in France, the basic principles of the common law in England, the natural rights of Man in the United States, and respect for human dignity, freedom, democracy, human rights, pluralism, non-discrimination, tolerance, justice, solidarity and equality in the European Union. Substantive theories of the rule of law appeal to comprehensive social and political philosophies. ${ }^{256}$

Outside the Western World, the Western conception of the rule of law is either refuted, as in the socialist systems where law is a means to achieve the transformation of society and therefore the law cannot bind the state, or transformed, as in Islamic law that excludes secularism, according to which subordination of the Islamic rulers to the Sharia is subject to the control (in the past) of Islamic scholars and (in the present day) of Islamic courts. Additionally, the rule of law can only partially be accepted into a wide variety of political agendas, either in its formal or in its substantive aspects (in many countries in Latin America, Asia, and Africa).

States that rely on law to govern, but that do not accept the basic requirement that law binds the state, state actors, and states in transition to a democratic form of government, cannot be identified as states governed by the "rule of law," but rather, are best described as states "ruled by law" (the fa zhi of old China). States that rely on rules of proper behaviour, based on philosophical conceptions (the $l i$ of old China), are better described as

255. Support for the formal conception of the rule of law include Joseph Raz, The Rule of Law and its Virtue, 93 L.Q. Rev. 195; Joseph RaZ, The Authority of LaW (1979); Scalia, supra note 226.

256. A third option, different from the formal and substantive conceptions of the rule of law is offered by Paul Craig, Formal and Substantive Conceptions of the Rule of Law: An Analytical Framework, 1997 Pub. L. 467; see also Lon L. FulLer, The Morality of LAW (1969). On Fuller's principles of legality see M. Kramer, Objectivity and the Rule of Law 186 et seq. (Cambridge Univ. Press 2004). On the rule of law as a morally precious desideratum, see $i d$. at 102. 
belonging to the "rule of man" or ren zhi. States that rely on religious moral laws, like Islam, do not belong either to rule by the law of the state or the rule of law independent from the state, but to the rule of the Sharia.

This implies that any universal definition of the rule of law will have to incorporate at least three principles: (i) the principle that power may not be exercised arbitrarily, which requires a rejection of the rule by man and requires that laws should be prospective, accessible, and clear; (ii) the principle of supremacy of the law, which distinguishes the rule of law from the rule by law and implies acceptance of the principle of separation of powers or the idea that the law applies to all, including the sovereign, with an independent institution, such as a judiciary, to apply the law to specific cases; and (iii) the principle that the law must apply to all persons equally, offering equal protection without discrimination or the idea that the law should be of general application and should be capable of being obeyed. There is controversy over the question of whether the rule of law requires respect for fundamental rights, the exact content of which has been illustrated as varying in the different legal systems of the world. On this last question, international law may offer an answer.

\section{The Rule of Law in International Law}

Can the principles on the rule of law laid down in the domestic systems of the states discussed above be applied at the international level? Is there an international rule of law forming part of international law that is binding upon all international organizations and states? What is the content of such a rule? Can the rule of law, understood as requiring the political power to act without arbitrariness, upholding the supremacy of the law, and equal treatment before the law be translated into international law? Rosalyn Higgins, former President of the International Court of Justice, has suggested that this core meaning of the rule of law would require the existence of an international rule of law according to which:

$[\mathrm{T}]$ here should be an executive reflecting popular choice, taking non-arbitrary decisions applicable to all for the most part judicially reviewable for constitutionality, laws known to all, applied equally to all, and independent courts to resolve legal disputes and to hold accountable violations of criminal law, itself applying the governing legal rules in a consistent manner. ${ }^{257}$

257. Rosalyn Higgins, Former President, The Int'l Court of Justice, The ICJ and the Rule of Law, address before the United Nations University 2-3 (Apr. 11, 2007). 
Can international law ensure such a conception of the rule of law? How does international law apply the rule of law to itself?

\section{Is There An International Rule of Law?}

Above all, there is no evidence of a general practice of states accepting the rule of law as international customary law, ${ }^{258}$ nor is there evidence of a belief that such a practice is rendered obligatory by the existence of an international rule of law or "opinio juris sive necessitatis." 259 In addition, it is obvious that at present, international law has not yet achieved the normative and institutional level required by the rule of law described by Higgins. The relationship of international law and the rule of law has been the subject of several doctrinal analyses, including an important essay by S. Cherterman, ${ }^{260}$ which have identified the following shortcomings:

The United Nations Charter, which is the expression of the constitutional international $\operatorname{order}^{261}$ (the UN assembles 192 states), does not explicitly provide that its organs and the member states are subordinated to the principle of the rule of law. Indeed the UN Charter does not use the expression "rule of law" and although there are several references to the expression "rule of international law" in the UN Charter, such references are simply exhortatory. Thus, the Preamble to the UN Charter expresses the determination of the peoples of the UN to "establish conditions under which justice and respect for the obligations arising from treaties and other sources of international law can be maintained." Article 1(1) of the Charter states that a purpose of the UN is the adjustment or settlement of international disputes or situations that might lead to a breach of peace in conformity with the principles of justice and international law. Furthermore, Article 13(1)(a) of the Charter establishes, as one of the important roles of the General Assembly, the initiation of studies and the issuance of recommendations for the purpose of "encouraging the progressive development of international law and its codification."

Furthermore, the legal mechanisms established in the Charter for the operation of the $\mathrm{UN}$ do not necessarily prevent the UN organs from using the power conferred upon them in an arbitrary manner. In particular, the Security Council decision on the procedure for imposing targeted sanctions by listing terrorists and freezing their assets without regard for the rules of transparency or the possibility of formal review

258. Asylum Case (Colom. v. Peru) 1950 I.C.J. 266, 276-78 (Nov. 20). See in general the collective

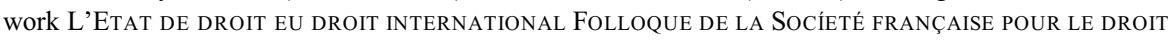
INTERNATIONAL (Pedone 2009).

259. North Sea Continental Shelf (F.R.G. v. Den.; F.R.G. v. Neth.) 1969 I.C.J. 3 (Feb. 20).

260. Simon Chesterman, An International Rule of Law?, 56 Aм. J. Comp. L. 331, 351-54 (2008).

261. Thomas M. Franck, Is the UN Charter a Constitution?, in Verhandeln Für Den Frieden: Liber Amicorum Tono Eitel 95 (Jochen Abr Frowein et al. eds., 2003). 
has been the subject of strong criticism. ${ }^{262}$ This has been the subject of demands for "fair and clear procedures" for listing and delisting, ${ }^{263}$ demands that have resulted in a clear, although not yet completely satisfactory, improvement of such procedures. ${ }^{264}$ The question has been raised whether the United Nations organization is bound by the treaties which have been negotiated and concluded under UN auspices. ${ }^{265}$ Although the United Nations possesses legal personality, ${ }^{266}$ it is not a party to the international conventions on human rights which have been negotiated under its auspices or monitored through its agencies. The question of whether the organization is bound by those instruments has gained momentum as a result of a series of cases arising from the establishment of targeted financial sanctions against terrorists. The EU General Court, called the Court of First Instance prior to the Lisbon Treaty taking force, has held that decisions adopted by the Security Council under the provisions of Article 103 and Chapter VII of the UN Charter are binding upon all states, but must conform to the norms of jus cogens, i.e.:

$[\mathrm{T}]$ he Court is empowered to check, indirectly, the lawfulness of resolutions of the Security Council in question with regard to jus cogens, understood as a body of higher rules of public international law binding on all subjects of international law, including the bodies of the United Nations, and from which no derogation is possible. ${ }^{267}$

This judgment of the General Court stands as one of the few cases in which a court has reviewed indirectly the validity of action by the UN Security Council, ${ }^{268}$ in particular because on appeal to the Court of Justice of the European Union, the Court of Justice appears to have abandoned the reasoning of the General Court with regard

262. Simon Chesterman, The Spy Who Came In from the Cold War: Intelligence and International Law, 27 Mich. J. INT'L L. 1071, 1109-20 (2006).

263. 2005 World Summit Outcome Document, 134 U.N. Doc. A/Res/60/1 (Oct. 24, 2005). Such anxieties may be contrasted with the elaborate protections established by the Security Council in its resolutions establishing the International Criminal Tribunals for the former Yugoslavia and Rwanda, see Chesterman, supra note 262, at 1113.

264. S.C. Res. 1904, U.N. Doc. S/RES/1904 (Dec. 17, 2009).

265. Of course disputes between the staff and the U.N. are subject to the control of the U.N. Administrative Tribunal (U.N. Admin. Trib.), which was established by the General Assembly Resolution 35/A (IV) (1949), an independent organ competent to hear and pass judgment upon applications by staff members alleging breaches of these terms of their contracts of judgment. See, e.g., the Chinese Translators Case, Qin Zhon and Yao v. Secretary-General of the United Nations, Judgments U.N. Admin. Trib., No. 482, U.N. Doc. AT/DEC/482 (1990).

266. See Advisory Opinion on the Reparation for Injuries Suffered in the Service of the United Nations, 1949 I.C.J. 174 (Apr. 11, 1949).

267. Case T-306/01, Ahmed Alu Yusuf \& Al Barakaat, Int'l Found. v. Council of the European Union \& Comm'n of the European Cmtys. (2005). See also Case T-49/04, Faraj Hassan v. Council of the European Union \& Comm'n of the European Cmtys. (2006); Case T-253/02, Chafiq Ayadi v. Council of the European Union \& Comm'n of the European Cmtys. (2006); Case T-315/01, Yassin Abdulla Kadi v. Council of the European Union \& Comm'n of the European Cmtys., 2005 E.C.R. II-3649.

268. See also Legal Consequences for States of the Continued Presence of South Africa in Namibia, where the ICJ adopted an Advisory Opinion in which it referred to 'a situation which the Court has found to have been validly declared illegal' by the UN Security Council, 1971 I.C.J. REP. 16, 54. In Prosecutor v. Tadic a/k/a "Dule," the International Criminal Tribunal for Former Yugoslavia (ICTY) held that "neither the text nor the spirit of the Charter conceives of the Security Council as legibus solutus' (unbound by law), Appeal of 2 October 1995, Case IT94-1-AR72 105, 105 I.L.R. 453 (1997). 
to the power to review, even indirectly, the validity of the action by the Security Council. ${ }^{269}$

With regard to the subjection of the United Nations organization to International Humanitarian Law, the doctrine rejects a 1952 American Society of International Law opinion that doubted whether international humanitarian law was fully applicable to the forces of the UN and suggested that the UN was free to "select such of the laws of war as may see to fit its purposes." ${ }^{270}$ At present, the doctrine requires that the states that participate in UN enforcement actions be bound by their individual obligations under the jus in bello. ${ }^{271}$ Any doubt about the applicability of international humanitarian law to the United Nations organization has been set aside by an administrative order by the UN Secretary General. ${ }^{272}$ However, the doubts persist with regard to the case where the UN Security Council (UNSC) deploys forces pursuant to Article 43 of the UN Charter, i.e. by means of the forces made available to the UNSC as a result of international agreements concluded between member states, even though the doubts remain hypothetical since no such agreement has been concluded so far. ${ }^{273}$

Unlike domestic legal system of states, the review of legality in international law is based on voluntary submission to judicial institutions, the rule of consent to jurisdiction. In particular, the International Court of Justice (ICJ) is not a constitutional court because it lacks jurisdiction to review the legality and any ultra vires action of the UN organs. Instead, the Charter intentionally leaves the interpretation of the scope of the powers of the UN organs to the organs themselves, ${ }^{274}$ even though it is possible for an organ to ask for an advisory opinion of the ICJ in accordance with Article 96 of the UN Charter. In particular, the question of the scope of the powers of the UN Security Council (UNSC) has been the subject of contention. The Lockerbie rulings constitute an interesting illustration: in these cases both the UNSC and the ICJ contemplated the issue that arose from the bombing of the Pan Am flight 103 over Lockerbie in Scotland on December 21, 1988. Although the ICJ declined to rule on the merits and held that the UNSC had acted within its powers, ${ }^{275}$ the rulings have been interpreted as an implicit assertion by the ICJ of its power to determine the limits of the discretion by the UN Security Council. ${ }^{276}$ It has been suggested that these rulings constitute significant judicial

269. See joined cases C-402/05P and C-415/05P, Kadi and Al Barakaat v. Council of the European Union \& Comm'n of the European Cmtys., 58 ICLQ 229, 230 (2009). For a study of the challenge of terrorism to the rule of law see Y.C. PAYE, LA Fin DE L'ETAT DE DRoit (La Dispute ed., 2004).

270. See Chesterman, supra note 260, at 353 n.121.

271. D.W. Bowett, United Nations Forces: A Legal Study of the United Nations Practice 503-06 (1964).

272. U.N. Secretary-General, Observance by United Nations Forces of International Humanitarian Law, U.N. Doc. ST/SGB/1999/13 (Aug. 6, 1999). See also the so-called Zagreb Resolution of 1971, Institut de Droit International, First Commission, Rap. Paul de Vischer (Sept. 3, 1971).

273. Christopher Greenwood, Protection of Peacekeepers: The Legal Regime, 7 Duke J. Comp. \& INT'L L. 185 (1996).

274. See Chesterman, supra note 260 , at 353 n. 125.

275. Cases Concerning Questions of Interpretation and Application of the 1971 Montreal Convention Arising from the Aerial Incident at Lockerbie, Provisional Measures (Libya v. UK), 1992 I.C.J. 3, 11 (Apr. 14) and Provisional Measures, (Libya v. US) 1992 I.C.J. 114, 122 (Apr. 14); see also (Libya v. UK and the USA), 27 Apr. and 29 June, 1999 I.C.J. 975 (1999).

276. Chesterman, supra note 260, at 354 (citing Thomas M. Franck, The "Powers of Application": 
decisions comparable to the U.S. Supreme Court's decision in Marbury v. Madison, which, as we have seen, upheld the power of the U.S. Supreme Court to determine whether the executive power had acted in accordance with the U.S. constitution. ${ }^{277}$ The UNSC has also created international criminal tribunals, to the exclusion of any domestic judicial procedure, in order to adjudicate on the criminal activities that arose from the conflicts in the former Yugoslavia (the International Criminal Tribunal for the former Yugoslavia) ${ }^{278}$ (ICTY) and in Rwanda (the International Criminal Tribunal for Rwanda). ${ }^{279}$ Those tribunals have been criticized for spending significant resources while succeeding in prosecuting only a few individuals and for achieving little lasting impact on the judicial institutions of the territories concerned. Other hybrid tribunals such as the Special Court for Sierra Leone and the Extraordinary Chambers in the Court of Cambodia were established by means of bilateral agreements between the $\mathrm{UN}$ and the countries concerned in order to ensure international supervision over the development of national institutions. However, they have had limited success. ${ }^{280}$

Finally, the establishment of the International Criminal Court (ICC) to adjudicate on the most serious criminal offences in international law may be considered a rather modest achievement. On one hand, the ICC does not exercise primary jurisdiction, its jurisdiction being complementary to those of national courts. Thus, the Court must respect national sovereignty and national judicial procedures and must encourage national prosecution where possible. On the other hand, pursuant to Article 16 of the Rome Statute of the ICC, the UNSC retains the power to defer prosecutions for a renewable period of one year. This reflects a tension between two international interests, the promotion of justice and the achievement of peace. ${ }^{281}$ Finally, the UN Security Council has assumed quasi-legislative functions in its resolutions, adopted under Chapter VII of the UN Charter, relating to counterterrorism and the fight against proliferation of weapons of mass destruction. ${ }^{282}$ These resolutions have been criticized for having been adopted "inappropriately" under

Who Is the Ultimate Guardian of UN Legality?, 86 AM. J. INT'L L. 83 (1992), who is said to have interpreted the I.C.J. ruling focusing on what the Court "did not say rather than what it did.").

277. Id. at 353 (citing Marbury v. Madison, 5 U.S. (1 Cranch) 137 (1803)).

278. S.C. Res. 827, U.N. Doc. S/RES/827 (May 25, 1993).

279. $I d$.

280. Agreement between the United Nations and the Government of Sierra Leone on the Establishment of a Special Court for Sierra Leone, U.N.-Sierra Leone, Jan. 16, 2002, contained in UN document S/2002/246, Appendixes II and III; Agreement between the United Nations and the Royal Government of Cambodia concerning the Prosecution under Cambodian Law of Crimes Committed during the Period of Democratic Kampuchea, U.N.-Cambodia, June 6, 2003, UN document A/57/806.

281. See L. Condorelli \& S. Villalpando, Referral and Deferral by the Security Council, in A. Cassese, P. Fraeta \& Y.R.W.D. Jones, The Rome Statute of the International Criminal Court, A Commentary 627 (Oxford 2002); M. Bergsmo \& J. Pejic, Article 16: Deferral of Investigation or Prosecution, in Commentary on the Rome Statute of the International Criminal Court (O. Triffterer ed., Hart Publishing 2d ed. 2008).

282. See, e.g., Security Council Resolution 1368 (2001); Security Council Resolution 1373 (2001); Security Council Resolution 1540 (2004); Security Council Resolution 1566 (2004); Security Council Resolution 1695 (2006); Security Council Resolution 1696 (2006); Security Council Resolution 1747 (2007); Security Council Resolution 1803 (2008); Security Council Resolution 1810 (2008); Security Council Resolution 1835 (2008); Security Council Resolution 1874 (2009) and Security Council Resolution 1887 (2009). 
Chapter VII while establishing "abstract rules of general application" and for having given pre-eminence to the Security Council at the expense of the "more democratic" General Assembly. ${ }^{283}$

Finally, although the United Nations Charter provides for sovereign equality of its members in Article 2(1) of the UN Charter, the structure of the UN Security Council with permanent seats for some states that also hold the right to veto its decisions suggests that this principle does not apply to the Security Council.

Indeed, in the ELSI case, a Chamber of the International Court of Justice held that:

[T] he fact that an act of a public authority may have been unlawful in municipal law does not necessarily mean that that act was unlawful in international law . . . . Nor does it follow from a finding by a municipal court that an act was unjustified, or unreasonable, or arbitrary, that that act is necessarily to be classed as arbitrary in international law, though the qualification given to the impugned act by a municipal authority may be a valuable indication. ${ }^{284}$

In international law, the Court held, arbitrariness was to be defined not as a breach of a rule of law, but as inconsistent with the rule of law. In the Tadic case, the ICTY held that the rule of law was a matter for national courts rather than for international courts. ${ }^{285}$ The issue there was whether the ICTY itself was "established by law" within the meaning of Article 14 of the International Covenant on Civil and Political Rights (ICCPR), so that the international trial of Tadic was in accordance with international human rights standards. In response, the ICTY appeared to say that there was no problem - that these standards were set for national, not international courts: "the principle that a tribunal must be established by law . . . is a general principle of law imposing an international obligation which only applies to the administration of criminal justice in a municipal setting. ${ }^{286}$ It is submitted that as far as the Tadic ruling by the ICTY implies: [T] hat international institutions including judicial institutions are in principle exempt from international standards.

283. See J. Alvarez, Hegemonic International Law Revisited, 97 AM. J. INT'L L. 873 (2003); S.A. Talmon, The Security Council as World Legislature, 99 Am. J. INT'L L. 175 (2005).

284. Case concerning Elettronica Sicula Spa (ELSI) (United States v. Italy), 1991 I.C.J. 312, 380 (July 20, 1989).

285. Prosecutor v. Tadic, Appeals Chamber, 105 I.L.R. 453 (ICTY 1997), discussed in James Crawford, The Drafting of the Rome Statute, in From Nuremberg to The Hague 129-33 (Philippe Sands ed., 2003).

286. Prosecutor v. Tadic, Appeals Chamber, 105 I.L.R. 453, 472-73 (ICTY 1997). 
Such a position is indefensible in the long term, even if it were morally acceptable. In the long run national systems founded on the rule of law cannot tolerate review by international systems which are not so founded, especially as to otherwise internal matters. ${ }^{287}$

A second set of reasons given by the ICTY in Tadic interprets the requirements of the rule of law at the international level so as to ensure at least substantial compliance with the underlying values. ${ }^{288}$ This second line of analysis would have been a sufficient basis for the trial in Tadic to go ahead, ${ }^{289}$ without specifying that international courts do not have to comply with the international law standard for courts generally. ${ }^{290}$

So, does international law apply the rule of law to itself? In my view, there is above all, a need for the rule of law "as a moral virtue" at the international level, i.e. a rule of law that is a moral requirement when necessary to enable a law to perform a good/useful social function. ${ }^{291}$ There is such a need at least to the extent that international law approximates a system of public order between states as legal orders in their own right, or to the extent that it performs tasks of adjudication, assessment, or review of domestic decision-making in areas or matters in which international law itself prescribes compliance with the rule of law. ${ }^{292}$ But the application of the basic value of the rule of law at the international level is conditioned on the absence of the sophisticated legal mechanisms that exist in internal legal systems and the requirement to decide by consensus as a general rule. It is submitted that, within these parameters, there exists an international rule of law which has the following characteristics:

287. James Crawford, International Law and the Rule of Law, 24 ADEL. L. Rev. 3, 10 (2003).

288. Id. at $472-73$.

289. It should be noted that the defendant in Tadic was sentenced to 25 years imprisonment, later reduced to 20 years by the Appeals Chamber. Prosecutor v. Tadic (Revision of Sentence), Appeals Chamber, 124 I.L.R. 213, 214 (2003).

290. Crawford, supra note 287, at 10. Crawford indicates that there is a real question whether even the doctrine of approximation is enough for a criminal court. Unlike in civil law, there is a serious problem in the field of criminal law with ad hoc courts, and it was this factor which gave such impetus to the movement for an International Criminal Court created by multilateral treaty. Concerns about the rule of law were a major factor for many governments that supported the Rome Statute and the creation of the International Criminal Court. Crawford conceives the present system of public order at the international level "not as a hierarchy of international executive power masquerading as law and prevailing over national systems - the Vattelian system that Philip Allott criticises in his work - but [rather as] an interpretation of legal orders each with its own internal rules of hierarchy, each acknowledging the existence and validity of the other." Id., citing Philip Allott, Eunomia: New Order for A NeW World 488 (1990).

291. RAZ, supra note 255. An interesting attempt to establish a necessary connection between law and morality may be found in LON L. FulLer, THE MORALity of LAW (1969).

292. See Crawford, supra note 287 , at 10. 
1. The element of the rule of law requiring an absence of arbitrary power is embodied in the fundamental principle that agreements are binding pacta sunt servanda. It is also evident in efforts to establish international protection of human rights, governance of international trade, and international security institutions. However, there are serious practical difficulties with international law. ${ }^{293}$ On the one hand, as we have seen, although the decisions of the Security Council are subject to the authority of the Charter, there is no regular institutional means for bringing the Security Council to act within the limits laid down by the Charter: the Security Council has delimited maritime territory, ${ }^{294}$ decisively determined the outcome of judicial proceedings, ${ }^{295}$ dealt with issues that were before the International Court of Justice, ${ }^{296}$ and established international criminal tribunals. ${ }^{297}$ In addition, the Security Council is either "used" as a legitimating mechanism (e.g., the policy of the United States towards Iraq), or its authority is ignored. In these contexts the rule of law is insecure and precarious. ${ }^{298}$ On the other hand, one must recall the virtual universality of the United Nations and the extreme character of many of the situations with which the Security Council has had to deal. So, if there is a growing appearance of the rule of law at the international level, it is not surprising that this may be happening slowly and in some fields more than others. ${ }^{299}$

2. International law now has a fairly well-developed set of techniques that aim to deal with the question of non-retroactivity, in relation both to treaties and to customary or general international law. Specific problems may arise with retroactivity in the criminal law, but that is no different from problems that arise, for example, in common law systems. The European Court of Human Rights has dealt, in a rather subtle way, with the non-retroactivity issue in

293. Luigi Ferrajoli, The Past and the Future of the Rule of Law, in THE Rule of LAw, supra note 6 , at 323,349 .

294. See Crawford, supra note 287.

295. S.C. Res. 1483, ๆ 22, U.N. Doc. S/RES/1483 (May 22, 2003).

296. S.C. Res. 748 (Mar. 31, 1992); S.C. Res. 731, \3 (Jan. 21, 1992).

297. S.C. Res. 955, 1 1, U.N. Doc. S/RES/955 (Nov. 8, 1994).

298. Chesterman, supra note 260, at 348 (suggesting that since the mid-1990s the UNSC enforcement powers "have increasingly been used to support, supplant, or replace domestic legal systems").

299. See William W. Bishop, The International Rule of Law, 59 MicH. L. Rev. 553 (1961) (considering that the international rule of law includes reliance on law as opposed to arbitrary power in international relations). 
domestic criminal law. At the international level, it may at least be presumed that the definitions of crimes in the ICC Rome Statute reflect general international law, and therefore there is no problem of unjustified retroactivity.

3. As a general rule, international law applies the principle of supremacy of the law in the form of subordination of all states to the law (a principle which owes its origins to Natural Law thinking) and purports to do so on a basis of equality before the law in the sense of equality of legal personality and capacity (notwithstanding the voting system in the Security Council).

4. Progress has been made at the institutional level with regard to the requirement of the rule of law that the judiciary must be independent and "established by law." The International Court of Justice has been developing its procedures to resolve particular issues of independence, and it has also expanded its role. ${ }^{300}$ The existence of a large proportion of international judicial or arbitral decisions made by ad hoc panels prevents at least an impression of selectivity and of arbitrariness and has expanded international judicial settlement to cover very varied fields. Although the basic rule of consent to jurisdiction has been repeatedly reaffirmed, progress has been made, in particular with the European Union and the European system for the protection of human rights and fundamental freedoms of the Council of Europe, which provides for a European Court of Human Rights. This makes it possible for an individual to bring a case against a state before an international court. In the field of international trade, disputes between states are now regularly settled by the revolutionary machinery established by the World Trade Organization ("WTO") agreement of 1994, which also provides for an appellate body that is, in effect, an international supreme trade court. In fact, that court has developed an impressive body of caselaw in a short time. To a lesser extent, there is also Part XV of the United Nations Convention on the Law of the Sea. ${ }^{301}$ Thus, although it is still utopian to suggest that the basic rule of consent to

300. Mahomedali Currim Chagla, Rule of Law and the International Court of Justice, 54 Ам. Soc'Y InT'L L. Proc. 237 (1960); Fiona de Londras, Dualism, Domestic Courts, and the Rule of International Law, in Comparative Perspective, supra note 11, at 217, 217.

301. United Nations Conventions on the Law of the Sea, Dec. 10, 1982, 1833 U.N.T.S 3. 
jurisdiction is disappearing, the emergence of more integrated systems of law is a reality. ${ }^{302}$

5. Therefore, it is submitted that important progress has been achieved in the development of an international rule of law and that the remaining shortcomings should not constitute a roadblock for international lawyers that prevents continued work on the rule of law as a fundamental goal. ${ }^{303}$ For, "on empirical grounds, given the number of civil wars, wars of secession and coups d'état since ... 1945, a good case can be made for saying that ... international law is more efficient than public law within states." ${ }^{304}$

This brings us to the question as to how international law applies the rule of law to others, how international law performs its vital tasks on the rule of law, and how the rule of law is applied at international level by subjects of international law.

\section{The Implementation of the International Rule of LaW}

Among international organizations, the UN has undertaken a leading role on the rule of law in order to support the development, promotion, and implementation of international norms and standards in most fields of international law, particularly the protection of human rights, the promotion of development, and the maintenance of peace.

The Secretary General has made the unambiguous statement that "every nation that proclaims the rule of law at home must respect it abroad and that every nation that insists on it abroad must enforce it at home." ${ }^{305} \mathrm{He}$ has submitted various reports on the rule of law to the UN organs. ${ }^{306}$ The General

302. See Yuval Shany, The Competing Jurisdictions of International Courts and TRIBUNALS (2003). 260.

303. For a more pessimistic view of the rule of law in international law, see Chesterman, supra note

304. Ian Brownlie, The Rule of Law in International Affairs 14 (1998).

305. See U.N. Secretary-General, In Larger Freedom: Towards Development, Security and Human Rights for All, ๆ 133-39, delivered to the General Assembly, U.N. Doc. A/59/2005 (Mar. 21, 2005).

306. In his follow-up report to the outcome of the Millennium Summit entitled "In Larger Freedom: Towards Development, Security and Human Rights for All," the Secretary General of the UN identifies that "nowhere is the gap between rhetoric and reality_-between declaration and deeds — so stark and so deadly as in the field of international humanitarian law," and recommends to "embrace the responsibility to protect," to strengthen the rule of law "by universal participation in multilateral conventions," to include "justice as a vital component of the rule of law (inter alia by) . . cooperating fully with the International Criminal Court ... (and by considering) means to strengthen the work" of the International Court of Justice. Id. In his 2009 annual Report to the General Assembly on strengthening and coordinating United Nations 
Assembly has considered the rule of law as an agenda item since 1992, and with renewed interest since the 2001 Millennium Declaration, ${ }^{307}$ and has adopted several resolutions in this regard ${ }^{308}$ calling for compliance with the decisions of the International Court of Justice, for non-discrimination, and for an inventory of activities on the rule of law by the UN organs. The UN Security Council has held a number of thematic debates on the rule of law ${ }^{309}$

rule of law activities, the Secretary General indicates that the UN work on the rule of law "rests on a shared vision across the spectrum of the United Nations aims of peace and security, social and economic progress, and human rights, ... (the UN activities) are founded on the Charter and international norms and standards. The principle that all individual and entities - including states - are accountable to the law drives efforts in the field .... Ultimately, legal protection as the means to achieve freedom from fear and freedom from want is the most sustainable form of protection." The Secretary-General, Annual Report on Strengthening and Coordinating United Nations Rule of Law Activities, delivered to the Security Council, U.N. Doc. S/2004/616 (Aug. 17, 2009). With regard to the Security Council, in his report on the rule of law and transitional justice in conflict and post-conflict societies, the Secretary General suggests to "support domestic reform constituencies, help build the capacity of national justice sector institutions, facilitate national consultation on justice reform and transitional justice and help fill the rule of law vacuum evident in so many post-conflict societies." The Secretary-General, Report of the Secretary-General on the Rule of Law and Transitional Justice in Conflict and Post-Conflict Societies, delivered to the Security Council, U.N. Doc. S/2004/616 (Aug. 23, 2004).

307. United Nations Millennium Declaration, G.A. Res. 55/2, U.N. Doc. A/RES/55/2 (Sept. 18, 2000) (reaffirming the commitment of all nations to the rule of law as the all-important framework for advancing human security and prosperity) [hereinafter Millennium Declaration].

308. Id. (stating that the UNGA resolves to "strengthen respect for the rule of law in international as national affairs and, in particular, to ensure compliance by member States with the decisions of the International Court of Justice, in compliance with the Charter of the United Nations, in cases to which they are parties"); G.A. Res. 62/128, U.N. Doc. A/RES/62/128 (Jan. 29, 2008); G.A. Res. 62/70, \3, U.N. Doc. A/RES/62/70 (Jan. 8, 2008) (indicating that the Resolution "invites the International Court of Justice, the UN commission on International Trade Law and the International Law Commission to comment . . o on their current roles in promoting the rule of law"); G.A. Res. 61/39, U.N. Doc. A/RES/61/39 (Dec. 18, 2006) (proclaiming that the promotion of and respect for the rule of law "should guide the activities of the United Nations and of its Member States," and requesting that the Secretary General "prepare an inventory" of the current activities of the various UN organs and departments); G.A. Res. 60/1, 134, U.N. Doc. A/RES/60/1 (Oct. 24, 2005) (endorsing the recommendations of the UN Secretary General's report of the outcome of the Millennium Summit, calling in addition "upon states to continue their efforts to eradicate policies and practices that discriminate against women").

309. The President of the Security Council, Statement by the President of the Security Council, delivered to the Security Council, U.N. Doc. S/PRST/2006/28 (June 22, 2006) (discussing the rule of law and maintenance of international peace and security); The President of the Security Council, Statement by the President of the Security Council, delivered to the Security Council, U.N. Doc. S/PRST/2005/30 (July 12, 2005) (discussing the role of the Security Council in humanitarian crisis); The President of the Security Council, Statement by the President of the Security Council, delivered to the Security Council, U.N. Doc. S/PRST/2004/32 (Sept. 10, 2004) (discussing Haiti); The President of the Security Council, Statement by the President of the Security Council, delivered to the Security Council, U.N. Doc. S/PRST/2004/2 (Jan. 26, 2004) (discussing post-conflict national reconciliation); The President of the Security Council, Statement by the President of the Security Council, delivered to the Security Council, U.N. Doc. S/PRST/2003/15 (Sept. 24, 2003) (discussing justice and the rule of law). 
and justice, post-conflict national reconciliation, Haiti, humanitarian crises, and the maintenance of international peace and security. Important reports on the rule of law have been submitted ${ }^{310}$ within the context of conflict prevention and peace-keeping operations, which have led to the adoption of resolutions and to important statements of the President of the Security Council. ${ }^{31}$

In particular, the rule of law has been strongly promoted by the UN Security Council in its work in the field of peace and security. Of course, Article 84 of the UN Charter refers to the domestic law of the states in the context of trust territories (the last of which became independent in 1994), but Article 2(7) of the Charter specifically excludes matters "essentially within the domestic jurisdiction" from interference by the UN, except when the UNSC acts in its enforcement capacity for the purpose of preserving international peace and security under Chapter VII. Consequently, the UNSC has incorporated the concept of rule of law in many of its peace-keeping operations, ${ }^{312}$ and in some of them the components of the rule of law play a fundamental role. ${ }^{313}$ In both Kosovo since 1993 and in East Timor/TimorLeste from 1999-2002 the UN has had and still has direct responsibility for

310. The Secretary-General and the President of the Security Council, Report of the Panel on United Nations Peace Operations, delivered to the General Assembly and the Security Council, U.N. Doc. A/55/305, S/2000/809 (Aug. 21, 2000) (recommending inter alia "a doctrinal shift in the use of civilian police, other rule of law elements and human rights experts in complex peace operations to reflect an increased focus on strengthening rule of law institutions and improving respect for human rights in postconflict environments").

311. The President of the Security Council has also made statements on the rule of law on behalf of the Security Council, and in particular with regard to the protection of civilians in armed conflict, in relation to peace-keeping operations and in connection with international criminal justice. See, e.g., The President of the Security Council, Statement by the President of the Security Council, delivered to the Security Council, U.N. Doc. S/PRST/2005/30 (July 12, 2005) (discussing the role of the Security Council in humanitarian crisis); The President of the Security Council, Statement by the President of the Security Council, delivered to the Security Council, U.N. Doc. S/PRST/2004/32 (Sept. 10, 2004) (discussing Haiti); The President of the Security Council, Statement by the President of the Security Council, delivered to the Security Council, U.N. Doc. S/PRST/2003/15 (Sept. 24, 2003) (discussing justice and the rule of law).

312. The Security Council incorporated the term "rule of law" as early as 1961 in the preamble of Resolution 161B (Feb. 21, 1961) on the deterioration of law and order in Congo: "Noting with deep regret and concern the systematic violations of human rights and fundamental freedoms and the general absence of the rule of law in the Congo." (The French text contains the expression l'absence générale de légalité au Congo.) The Security Council also referred to the "rule of law" in paragraph two of Resolution 1040 (Jan. 29, 1996) "where it expressed its support for the Secretary General's efforts to promote "national reconciliation, democracy, security and the rule of law in Burundi." (It should however be noted that the French text does not use the expression "rule of law," but the expression le rétablissement de l'ordre.) See Chesterman, supra note 260, at 348.

313. Id. 
the administration of justice (the so-called "executive powers,") including the control of the police and prison services. In Kosovo, before its declaration of independence, the High Representative could exercise "all legislative and executive authority . . . including the administration of the judiciary." 314 Additionally, the officials working for the Kosovo High Representative enjoyed personal or functional immunity from legal process while being unaccountable to the local population. ${ }^{315}$ Similar executive powers were conferred on the Office of the High Representative in Bosnia and Herzegovina. ${ }^{316}$ Ever since then, UNSC resolutions have continuously expanded the scope of the rule of law to include gender issues, the protection of children in armed conflict, the protection of civilians, and due process in the fight against terrorism. ${ }^{317}$

The United Nations also works to support a rule of law framework at national levels. In this regard, the UN Secretary General has indicated that "for the purpose of the United Nations:"

314. Interim Administration in Kosovo Reg. 1999/1, U.N. Doc. UNMIK/REG/1999/1 (July 25, 1999). For a criticism see C. Bull, No Entry Without a Strategy Building the Rule of Law Under UN Transitional Administration (UNU Press 2008).

315. S.C. Res. 1244, ๆ 10-11, U.N. Doc. S/RES/1244 (June 10, 1999).

316. See, e.g., S.C. Res. 1035 (Dec. 21, 1995); see also Chesterman, supra note 260, at 348.

317. The Security Council has adopted resolutions identifying elements of the rule of law under international law which include include "the willingness to incorporate a gender perspective into peacekeeping operations,” S.C. Res. 1325, 5 , U.N. Doc. S/RES/1325 (Oct. 31, 2000), the protection of children affected by armed conflict; S.C. Res. 1612, $\uparrow 1$, U.N. Doc. S/RES/1612 (July 26, 2005), and the protection of civilians in armed conflicts; S.C. Res. 1674, $\uparrow$ 5, U.N. Doc. S/RES/1674 (Apr. 28, 2006). In the fight against international terrorism, the Security Council has adopted a series of measures, sanctions and listing of terrorists providing an improved due process for listing and delisting (to be assisted by an Ombudsperson), and establishing a monitoring team, which will submit written, comprehensive and independent reports, to the Counter Terrorism Committee (CTC) and the Security Council Committee in accordance with the information and dialogue procedure established in Annex II to the resolution. S.C. Res. 1904, U.N. Doc. S/RES/1904 (Dec. 14, 2009) (referencing S.C. Res. 1822, U.N. Doc. S/RES/1822 (June 30, 2008); S.C. Res. 1735, U.N. Doc. S/RES/1735 (Dec. 22, 2006); S.C. Res. 1730, U.N. Doc. S/RES/1730 (Dec. 19, 2006); S.C. Res. 1699, U.N. Doc. S/RES/1699 (Aug. 8, 2006); S.C. Res. 1624, U.N. Doc. S/RES/1624 (Sept. 14, 2005); S.C. Res. 1617, U.N. Doc. S/RES/1617 (July 29, 2005); S.C. Res. 1566, U.N. Doc. S/RES/1566 (Oct. 8, 2004); S.C. Res. 1526, U.N. Doc. S/RES/1526 (Jan. 30, 2004); S.C. Res. 1455, U.N. Doc. S/RES/1455 (Jan. 17, 2003); S.C. Res. 1452, U.N. Doc. S/RES/1452 (Dec. 20, 2002); S.C. Res. 1390, U.N. Doc. S/RES/1390 (Jan. 16, 2002); S.C. Res. 1373, U.N. Doc. S/RES/1373 (Sept. 28, 2001); S.C. Res. 1363, U.N. Doc. S/RES/1363 (July 30, 2001); S.C. Res. 1333, U.N. Doc. S/RES/1333 (Dec. 19, 2000); S.C. Res. 1267, U.N. Doc. S/RES/1267 (Oct. 15, 1999); see also The Chairman of the Security Council, Report of the Security Council Committee Concerning Al-Qaida and the Taliban and Associated Individuals and Entities, delivered to the Security Council, U.N. Doc. S/2009/676 (Dec. 31, 2009). 
[The] rule of law refers to a principle of governance in which all persons, institutions and entities, public and private, including the state itself, are accountable to laws that are publicly promulgated, equally enforced and independently adjudicated, and which are consistent with international human rights norms and standards. It requires, as well, measures to ensure adherence to the principles of supremacy of law, equality before the law, accountability to the law, fairness in the application of the law, separation of powers, participation in decision-making, legal certainty, avoidance of arbitrariness and procedural and legal transparency. ${ }^{318}$

Thus, in its different programs and actions, the UN supports the establishment of national legal systems that incorporate a constitution (or its equivalent) as the highest law of the land. The constitution should include a clear and consistent legal framework, and implementation thereof; strong institutions of justice, governance, security, and human rights that are wellstructured, financed, trained and equipped; transitional justice processes and mechanisms; and a public and civil society that contributes to strengthening the rule of law and holding public officials and institutions accountable. These are the norms, policies, institutions, and processes that form the core of a society in which individuals feel safe and secure, where disputes are settled peacefully, where effective redress is available for harm suffered, and where all who violate the law, including the State itself, are held accountable. ${ }^{319}$

With regard to human rights, it is useful to recall that the Preamble to the 1948 Universal Declaration of Human Rights states that "it is essential if man is not to be compelled to have recourse, as a last resort, to rebellion against tyranny and oppression, that human rights would be protected by the rule of law." ${ }^{320}$ Additionally, the Declaration contains provisions ensuring rights, inter alia concerning the prohibition against arbitrary deprivation of liberty in Articles 3, 8, 9, 12, and 29, fair trials by independent judges in impartial tribunals in Articles 10 and 11, and ensuring equality before the law in Articles 6 and 7. Most international instruments and treaties on the protection of human rights incorporate the rights protected by the Universal Declaration,

318. The Secretary-General, Report of the Secretary-General on the Rule of Law and Tranisition Justice in Conflict and Post-Conflict Societies, delivered to the Security Council, U.N. Doc. S/2004/616 (Aug. 23, 2004). See also Democracy and the Rule of Law 472 (N. Dorseri \& P. Trifford eds., C.F. Press 2001).

319. Over 40 U.N. entities are engaged in rule of law issues and the Organization is conducting rule of law operations and programming in over 110 countries in all regions of the globe, with the largest presence in Africa. Any U.N. entities carry out activities in the same countries. Five or more entities are currently working simultaneously on the rule of law in at least 24 countries, the majority of which are in conflict and post-conflict situations.

320. Universal Declaration of Human Rights, G.A. Res. 217A, U.N. GAOR, 3d Sess. 1st plen. mtg., (Vol. III), U.N. Doc. A/810 (Dec. 12, 1948). 
but neither the International Covenant on Civil and Political Rights nor the International Covenant on Economic, Social, and Cultural Rights, which represent the other two pillars of the so-called "international bill of rights," mention the rule of law. ${ }^{321}$ In addition, there exist international codes of conduct for law enforcement officials, ${ }^{322}$ principles on the independence of the judiciary, ${ }^{323}$ and sophisticated conventions on discrimination ${ }^{324}$ that contain principles proper to the rule of law. Upon request, the United Nations offers technical and financial assistance to "national projects in reforming penal and correctional establishments, education and training of lawyers, judges and security forces in human rights, and any other sphere of activity relevant to the good functioning of the rule of law." ${ }^{325}$ A series of resolutions adopted by the General Assembly has established the rule of law as "an essential factor in the protection of human rights." ${ }^{326}$ Finally, progressive steps have been achieved by judicial decisions on human rights relating to the right to an effective remedy ${ }^{327}$ on which the General Assembly has adopted a series of Basic Principles in this area. ${ }^{328}$ This has been complemented by the rise of international criminal law and by landmark judicial decisions that have reduced the scope of the immunity of heads of state responsible for violations of human rights (e.g., the 1999 Pinochet judgment). ${ }^{329}$ In summary, the universal human rights instruments have been accepted voluntarily by the international community, which has agreed that universal human rights have

321. African Charter on Human Rights and People's Rights, June 27, 1981, 21 I.L.M. 58; American Convention on Human Rights, Nov. 22, 1969, 1144 U.N.T.S. 123; International Covenant on Civil and Political Rights, Dec. 16. 1966, 999 U.N.T.S. 171; European Convention for the Protection of Human Rights and Fundamental Freedom, Nov. 4, 1950, 213 U.N.T.S. 222.

322. Code of Conduct for Law Enforcement Officials, G.A. Res. 34/169, Annex, U.N. Doc. A/34/46 (1979).

323. Seventh United Nations Congress on the Prevention of Crime and the Treatment of Offenders, Milan, Italy, Aug. 26-Sept. 6, 1985, Basic Principles on the Independence of the Judiciary, U.N. Doc. A/CONF.121/22/REV.

324. Convention on the Elimination of All Forms of Discrimination Against Women, Dec. 18, 1979, 1249 U.N.T.S. 13; International Convention on the Elimination of All Forms of Racial Discrimination, Jan. 4, 1969, 660 U.N.T.S. 195.

325. World Conference on Human Rights, June 14-25, 1993, Vienna Declaration and Programme of Action, 9 69, U.N. Doc. A/CONF.157/23 (July 12, 1993).

326. Chesterman, supra note 260, at 345 n.74. See also Randall Peerenboom, Human Rights and Rule of Law: What's the Relationship?, 36 GEO. J. INT'L L. 809 (2005).

327. See, e.g., Castillo-Páez v. Peru, Inter-Am Ct. H.R. (ser. C) No. 34, qศ 82-83 (Nov. 3 1997).

328. Basic Principles and Guidelines on the Right to a Remedy and Reparation for Victims of Gross Violations of Human Rights Law and Serious Violations of International Humanitarian Law, G.A. Res 60/147, UN Doc. A/RES/60/147, (Dec. 16, 2005).

329. See R v. Bow St. Metro. Stipendiary Magistrate, ex parte Pinochet Ugarte (1999) 2 W.L.R. 827 (H.L.). 
to be protected by the rule of law. This constitutes a major contribution of international law to the definition of the rule of law accepted by all. ${ }^{330}$ Indeed, certain human rights (e.g., rights against torture, genocide, and slavery) may now be regarded as having entered into the category of customary international law and thus have become legally binding in the light of state practice. $^{331}$ In addition, human rights established under treaty law may constitute obligations erga omnes (jus cogens) for the states parties. ${ }^{332}$

The rule of law understood as a requirement of efficient and predictable justice, has also been a paramount means for the promotion of economic development. ${ }^{333}$ In its American origins in the 1960s, the U.S. Agency for International Development, the Ford Foundation, and other private American donors promoted the rule of law by focusing on an ambitious program to reform the laws and judicial institutions of countries in Africa, Asia, and Latin America. Within this framework, American donors created "the Law and Development Movement" (LDM) based on the assumption that law has the ability to shape social relations and that legislative change and judicial reform were instruments for social transformation. These donors emphasized legal education aimed at inculcating lawyers with legal ideas suited to the promotion of a political end, which was economic liberalism. However, the LDM soon became the subject of criticism for several reasons: first, the transformative power of the law is not supported by conclusive evidence and therefore remains a hypothesis; second, the sponsors of the LDM acted unilaterally without seeking the contribution of those countries that benefited from development aid; and third, the LDM took the American common law system as the model to be "transplanted" irrespective of the nature of the legal

330. According to Peerenboom, supra note 326, the rule of law protected under the Universal Declaration has been open to an interpretation that is more consistent with what has been described as "rule by law."

331. See Malcolm Shaw, International Law 275 (5th ed. 2008); Filartiga v. Pena-Irala, 630 F.2d 876 (2d Cir. 1980). See generally Theodor Meron, Human Rights and Humanitarian Norms as Customary Law (Oxford Clarendon Press 1989). See also the series of articles devoted to the study of human rights as pat of customary internatinoal law in the special volume 25 GA. J. INT'L \& COMP. L. (1995-96).

332. Barcelona Traction, Light and Power Company, Limited (Belg. v. Spain), 1970 I.C.J. 3, 32 (Feb. 1970); Military and Paramilitary Activities in and Against Nicaragua (Nicar. v. U.S.), 1986 I.C.J. 14, 18 , 38 (June 27).

333. See Chesterman, supra note 260 , at 346 . For an early link between the rule of law, the free market, and economic prosperity, see AdAm SMith, AN INQUiRY INTO THE NATURE AND CAUSES Of THE Wealth of Nations 15 (Edwin Cannon ed., 1976) (1776). See also Kristen E. Boon, Open for Business: International Financial Institutions, Post-Conflict Economic Reform, and the Rule of Law, 39 N.Y.U. J. INT'L L. \& POL. 513 (2007). 
culture of the recipient country. ${ }^{334}$ This led to the accusation that the LDM was a form of cultural imperialism and the Ford Foundation declared it a failure. $^{335}$

Subsequent efforts (e.g., by the World Bank) have put the emphasis on law as a means to empower both the market and market actors, rather than the state, by using the rule of law as an instrument to limit interference with the market. ${ }^{336}$ However, this change of focus from the state to the market has not resolved the underlying problem of the relationship between law, politics, democracy, and development. Thus, although there seems to be an almost universal acceptance by the international community of the need to promote the rule of law for development, there is no agreement on the means to bring it about or on the criteria to measure the rule of law. The 1992 Human Development Report by the UN Development Programme suggested five possible indicators: fair and public hearings in criminal cases; a competent, independent, and impartial judiciary; the availability of legal counsel; provision for review of convictions in criminal cases; and whether government officials or pro-government forces are prosecuted when they violate the rights and freedoms of other persons. ${ }^{337}$ In this regard, the World Bank has defined the rule of law as "the extent to which agents have confidence in and abide by the rules of society, and in particular the quality of contract enforcement, the police, and the courts, as well as the likelihood of crime and violence." It also included a combination of indicators from other sources to measure the rule of law in more than 200 countries and territories. ${ }^{338}$ Later assessments have been less negative, however, noting inter alia, that projects on law reform take many years to bear fruit. ${ }^{339}$

334. I. Glivanos, Rule of Law Promotion and Development, in LAW AND Justice Institutions, The WORLD BANK 11 (2009).

335. See St. Humphreys, Theatre of the Rule of Law 332 (Cambridge Univ. Press 2010); K. Dam, The Law Growth-Nexus (The Rule of Law and Economic Development) (Brookings Institution Press 2006); James Gardner, Legal Imperialism: American Lawyers and Foreign Aid in Latin America, 76 Aм. J. Int'L L. 196 (1980); John H. Merryman, Comparative Law and Social Change: On the Origins, Style, Decline \& Revival of the Law and Development Movement, 25 Ам. J. CoмP. L. 457 (1977).

336. See, e.g., Joel M. Ngugi, Policing Neo-Liberal Reforms: The Rule of Law as an Enabling and Restrictive Discourse, 26 U. PA. J. InT'L Econ. L. 513 (2005).

337. U.N. Dev'l Programme [UNDP], Human Development Report 1992 (1992), http:/hdr.undp.org/ en/reports/global/hdr1992/chapters/.

338. World Bank, A Decade of Measuring the Quality of Governance: Governance Matters 2006, at 3 (2006), http://siteresources.worldbank.org/INTWBIGOVANTCOR/Resources/17404791150402582357/2661829-1158008871017/booklet_decade_of_measuring_governance.pdf.

339. R. McCorquodale, The Rule of Law in International and Comparative Context, BRITISH InSTITUTE OF INTERNATIONAL AND COMPARATIVE LAW (2010); Bruce Zagaris Tamanaha, The Lessons of Law-and-Development Studies, 89 Am. J. INT'L L. 470, 472-73 (1995). 
More recently, the terms "governance" and "good governance" are being increasingly used by the development community. The concept of "governance" is not new. It refers to the process of decision making and the process by which decisions are implemented. Also, it focuses on the formal (the government of a state) and informal (the civil society) actors and structures. Good governance requires a society that ensures the participation of its people, transparency, responsiveness, consensus, equity, effectiveness, accountability, and a fair legal framework that is enforced impartially (rule of law). ${ }^{340}$ Thus, the good governance donors finance not only projects and structural adjustments but also government policies. Under "good governance," intergovernmental organizations such as the World Bank and the International Monetary Fund have financed government policies and political processes even if under their Charter they were not meant to do so. ${ }^{341}$ The developing countries have accepted the notion of "good governance" when they acknowledged in the 2005 World Summit Outcome Document that "good governance and the rule of law at the national and international levels are essential for sustained economic growth, sustainable development, and the eradication of poverty and hunger." 342 The UNDP Strategic Plan 2008-2011 on Democratic Governance, Crisis Prevention, and Recovery includes the rule of law as the core pillar of the UNDP's work. ${ }^{343}$ In addition, the UNDP adopted a global program on strengthening the Rule of Law in Conflict and Post-conflict situations (2008-2011). This program acknowledges that security and justice are essential in achieving the rule of law and that the rule of law is a precondition for the maintenance of peace and development. ${ }^{344}$

Thus, international law has created commitments and obligations concerning the rule of law at the international level with which states are to comply. Some of those commitments and obligations reflect elements of the rule of law that are present in national legal systems, while other commitments and elements (such as the protection by the rule of law of the universal human

340. See generally McCorquodale, supra note 339. See also UNDP, Governance for Sustainable Human Development (Jan. 1997), http://mirror.undp.org/magnet/policy/; Goran Hyden, Governance and the Reconstitution of Political Order, in State, Conflict and Democracy in Africa 179 (Richard Joseph ed., 1999).

341. Chesterman, supra note 5, at 4; F. Neate, ed., Rule of Law Perspectives from Around the Globe, LEXISNeXis (2009)

342. World Summit Outcome Document, supra note 263, ๆ 11. See also $\uparrow$ ๆ 21, 24(b).

343. UNDP, UNDP Strategic Plan 2008-2011, $\uparrow \uparrow 84,102$, U.N. Doc. DP/2007/43, (July 16, 2007).

344. UNDP, Strengthening the Rule of Law in Conflict/Post-Conflict Situations: Global Programme for Justice and Security (2008-2011), http://www.undp.org/cpr/documents/Rule _of_Law_Global_ Programme.pdf. 
rights that have been accepted by the international community as a whole) constitute a contribution of international law to a definition of the rule of law acceptable to the whole international community. Above all, international law has made it possible for the concept of universal human rights to be voluntarily accepted by the international community and for it to form a part of the universal definition of the rule of law.

The question arises about how states implement and promote the requirements of the international rule of law. ${ }^{345}$ Here, both the European Union and the United States have taken a leading role. It is now appropriate to look at how the principle of the rule of law operates in the external actions of both these actors.

\section{The Rule of Law in the External Action of the European Union}

The external action of the European Union on the international scene, with regard to the rule of law, is not a question of political choice. Rather, it is a legal duty not only established by international law but also laid down in the EU treaties. It is also inspired by the principles that provide the foundations for the Union's own creation and that it applies in its domestic jurisdiction. Article 21 of the (Lisbon) TEU provides that in its external action, the Union "seeks to advance in the wider world: democracy, the rule of law, the universality and indivisibility of human rights and fundamental freedoms, respect for human dignity, the principles of equality and solidarity, and respect for the principles of the United Nations Charter and international law." Indeed, Article 21, Paragraph 2 of the TEU (Lisbon) provides that external common policies and actions of the Union are defined in order to:

(a) safeguard its values, fundamental interests, security, independence and integrity; (b) consolidate and support democracy, the rule of law, human rights and the principles of international law; (c) preserve peace, prevent conflicts and strengthen international security, in accordance with the purposes and principles of the United Nations Charter, with the principles of the Helsinki Final Act and with the aims of the Charter of Paris, including those relating to external borders; (d) foster the sustainable economic, social and environmental development of developing countries, with the primary aim of eradicating poverty; (e) encourage the integration of all countries into the world economy, including through the progressive abolition of restrictions on international trade; (f) help develop international measures to preserve and improve the quality of the environment and the sustainable management

345. On the question of rule of law as a political weapon, see J.M. Maravall, The Rule of Law as a Political Weapon, in J.M. Maravall \& A. Przeworski, Democracy and the Rule of Law 242 (Cambridge Univ. Press 2003). 
of global natural resources, in order to ensure sustainable development; (g) assist populations, countries and regions confronting natural or man-made disasters; and (h) promote an international system based on stronger multilateral cooperation and good global governance.

In practice, how does the Union consolidate and support these principles and in particular democracy, the rule of law, human rights, and the principles of international law? How do the requirements of international law with regard to the rule of law apply in the EU?

\section{(i) The Union's predisposition to international law}

The Court of Justice of the European Union has ruled that the Union, when exercising its powers, must comply with international law including the judgments of the International Court of Justice. ${ }^{346}$ The Court has held that the two main sources of international law, both customary international law and treaties, concluded by the European Union and by its Member States, have binding force for the EU. In particular, customary rules of international law have binding force and, as such, must be applied in the European Union legal order ${ }^{347}$ In addition, the Court has upheld the direct effect of treaties in situations where the national law of some Member States do not accept it. ${ }^{348}$ The Court of Justice treats the European Convention on Human Rights as if it were binding upon the Union even if the Union itself is not yet a party to the Convention. ${ }^{349}$ In other cases, the Court has applied the following principles of international law: by assuming a new obligation which is incompatible with rights held under a prior treaty, a state ipso facto gives up the exercise of these rights to the extent necessary for the performance of its new obligation; ${ }^{350} \mathrm{a}$ state is precluded from refusing its own nationals the right of entry or residence, ${ }^{351}$ the territoriality principle is universally recognized in

346. Case C-286/90, Anklagemyndigheden v. Peter Micheal Poulsen Diva Navigation Corp., 1992 E.C.R. I-6019.

347. See Case C-192/99, The Queen v. Sec'y of State for the Home Dep't ex parte, Manjit Kaur, 2001 E.C.R. I-1237.

348. See Case C-53/96, Hermès Int'l v. FHT Mktg. Choice, 1998 E.C.R. I-3603; Joined Cases C-300 \& 392/98, Parfums Christian Dior v. TUK Consultancy \& Grüste v. Layher, 2000 E.C.R. I-11307.

349. See Case 4/73, Nold v. Comm'n, 1974 E.C.R. 491.

350. Case 10/61, Comm'n v. Italian Republic, 1962 E.C.R. 1, 10.

351. Case 41/74, Van Duyn v. Home Office, 1974 E.C.R. 1338, 1351. 
international law; $;{ }^{352}$ and the principle of good faith as recognized in customary international law $^{353}$ applies to the Union.

Also, the Court of Justice has interpreted United Nations Security Council Resolutions principally in two series of cases. The first series of cases concerned UN sanctions following the war in the former Yugoslavia (e.g., the Bosphorus Airways case). In those cases, the Court ensured both that the relevant Security Council resolutions were implemented in full, and that the interests of those affected by the imposition of the restrictive measures in question were taken into consideration. ${ }^{354}$ A second series of cases concerned UNSC Resolutions imposing restrictive measures in the context of the fight against terrorism (e.g., the Yusuf $f^{35}$ and $K_{a d i} i^{356}$ cases), where the EU General Court (the former Court of First Instance) accepted that UN law took precedence. ${ }^{357}$ However, on appeal, the Court of Justice held that, for the purpose of Union law, UN Security Council Resolutions must be implemented in accordance with the Union's fundamental values and respect for human rights. ${ }^{358}$

The Court of Justice has interpreted broadly the treaty-making power of the Union with the result that the Union has concluded a large number of treaties (more than one thousand). ${ }^{359}$ The Court has determined that even the so-called "mixed agreements" concluded jointly by the Union and its Member States, constitute "acts of the institutions of the Union" within the meaning of Articles 263 and 267 of the (Lisbon) Treaty on the Functioning of the European Union (TFEU), and that such mixed agreements fall within the jurisdiction of the Court to give preliminary rulings on interpretation of such agreements $^{360}$ pursuant to Article 267 of the TFEU, provided that the provisions of the agreement in question apply to both the Union and the Member States.

Another example of the predisposition of the Court towards international law is the recognition that the provisions of international treaties may have

352. Case 89/85, Osakeyhtiö v. Comm'n, 1988 E.C.R. 5233, 5243.

353. Case T-115/94, Opel Austria v. Council, 1997 E.C.R. II-39, II-71.

354. See, e.g., Case C-84/995, Bosphorus Hava Yollaria Turzin ve Ticaret v. Minister for Transp., Energy, and Commc'ns, Ir., 1996 E.C.R. I-3953.

355. Case T-306/01, Yusuf v. Council, 2005 E.C.R. II-3533.

356. Case T-315/01, Kadi v. Council, 2005 E.C.R. II-3649.

357. See Joined Cases C-400 \& 405 /05, Kadi v. Council, 2008 E.C.R. I-6351.

358. $I d$.

359. JACOBS, supra note 1 , at 57.

360. See Hermès Int'l, 1998 E.C.R. I-3603. 
direct effect within the EU legal order. ${ }^{361}$ The Court of Justice does not impose, as a condition of direct effect, the requirement of reciprocity that is often imposed by other legal orders, nor does it any longer impose the existence of a close relationship between the EU and a third country for the purpose of according direct effect to a treaty: for instance, in recent years the Court has held that both Association Agreements with European countries and a treaty embodying a less close relationship (the Partnership and Cooperation Agreement with Russia) have direct effect. ${ }^{362}$

A final example of the predisposition of the Court of Justice to other legal systems is its evolving approach to the system of the European Convention on Human Rights, a treaty to which the EU is not yet a contracting party, where the Court of Justice both has cited and has sought to follow the case-law of the European Court of Human Rights. ${ }^{363}$ The question arises as to how the EU's openness to international law is reflected in the external policy of the EU.

\section{(ii) The legal means of the EU external action on the Rule of Law}

The external action of the EU is guided by the principle that the rule of law presupposes a State's possession of independent constitutional and judicial authorities, a properly functioning public administration at local and central government level, a well-qualified and independent judiciary, an accountable law enforcement structure, an adequate, well-trained and disciplined police force, and an independent media. The EU considers that the rule of law underpins such goals as: equality before the Court, due process, executive accountability, good governance, and anti-corruption measures. ${ }^{364}$ Finally, the EU encourages third countries to respect human rights. The EU considers the rule of law an essential element of its agreements with third countries since it sees it as a prerequisite for stability outside its borders

361. Id. For other examples, see Joined Cases 21-24/72, Int'l Fruit Co., and others, Produktschap voor Groenten en Fruit, 1972 E.C.R. 1219 (holding that provisions of the General Agreement on Tariffs and Trade may bind the European Economic Community); Case C-377/02, Léon Van Parys v. Belgische Interventie en Restitutiebureau, 2005 E.C.R. I-1465 (holding that provisions of the World Trade Organization agreements may bind the European Community). The Court has more recently reached the same conclusion in respect of the United Nations Convention on the Law of the Sea. See Case C-308/06, Int'l Ass'n of Indep. Tanker Owners v. Sec'y of State for Transp., 2008 E.C.R. I-4057, 4058. See also JACOBS, supra note 1 , at 57-59.

362. Case C-265/03, Simutenkov v. Ministerio de Educación y Cultura, 2005 E.C.R. I-2579, 2607; JACOBS, supra note 1 , at $57-59$.

363. See JACOBS, supra note 1, at 57-61.

364. Anthony Arnull, The Rule of Law in the European Union, in Accountability AND Legitimacy in the European Union 239, 254 (Anthony Arnull \& Daniel Wincott eds., 2002). 
(Neighborhood), for economic and social development. ${ }^{365}$ The rule of law is a key element in EU technical and financial assistance, becase:

\begin{abstract}
Governance is a key component of policies and reforms for poverty reduction, democratisation and global security. This is why institutional capacity-building, particularly in the area of good governance and the rule of law is one of the six priority areas for EU development policy that is being addressed in the framework of EU programs in developing countries. ${ }^{366}$
\end{abstract}

More recently, within the framework of EU crisis management and conflict prevention, EU foreign policy has linked the rule of law to its security and defense policy. ${ }^{367}$ The EU rule of law requires that military, civil, and internal security institutions be subject to civilian power and accountable to legal authority.

\title{
(iii) Political clauses in EU agreements
}

For many years, the EU has included "political clauses" in its agreements with third states. ${ }^{368}$ With the inclusion of such clauses, the EU aims at promoting its values as well as as promoting its security interests. Moreover, political clauses constitute a specific tool that the EU can use to implement its most important policy objectives (respect for the rule of law, human rights, and non-proliferation) in its external action. Thus, the contents of the political clauses include EU policies on respect for the rule of law, democracy, human rights, non-proliferation (weapons of mass destruction as well as small arms and light weapons), the fight against terrorism, and cooperation with the International Criminal Court. The clauses are usually included in horizontal agreements, the so-called "EU framework agreements," where this term is generally taken to refer to Association Agreements and cooperation agreements such as Partnership and Cooperation Agreements, Trade,

365. Commission Communication on Wider Europe-Neighbourhood: A New Framework for Relations with our Eastern and Southern Neighbours, at 7, COM (2003) 104 final (Mar. 3, 2003). The role played by the rule of law in encouraging foreign investment has been challenged since there is evidence that it is not a determining factor. See Thomas Carothers, Promoting The Rule of Law Abroad: The Problem of Knowledge (Carnegie Endowment for Int'1 Peace, Working Paper No. 34, 2003).

366. Commission Communication on Governance and Development, \ 3, COM (2003) 615 final (Oct. 10, 2003).

367. Marise Cremona, The European Neighbourhood Policy: Legal and Institutional Issues 1-27, 11 (Stanford Inst. for Int'1 Studies Center on Democracy, Dev., and the Rule of Law, Working Paper No. $25,2004)$.

368. Council document 17370/08 of 16 December 2008. 
Development and Cooperation Agreements, and Economic and Technical Assistance Agreements. Sectoral Free Trade Agreements may not include political clauses if such clauses are already included in an existing horizontal framework agreement with the country concerned.

In the absence of any framework agreement, a provision on the rule of law, democracy, and human rights is, as a minimum, regularly included in free trade agreements. ${ }^{369}$ The EU considers that the rule of law, democracy, and human rights clause represents the core of EU values and, as a result, it is defined as an essential element of the EU agreements. ${ }^{370}$ This clause has been widely used, having been included in agreements with more than 120 countries. It follows that, in accordance with the Vienna Convention on the Law of Treaties, such agreements may be suspended or terminated in the case of serious violations of the clause by one of the contracting parties. ${ }^{371}$ In this regard, the EU systematically includes in its agreements a suspension mechanism in case of a serious violation of the rule of law, democracy, and human rights clauses. The mechanism includes a procedure that allows a reaction with immediate effect in case of a violation of an essential element. The mechanism may include the possibility for urgent dialogue within a specified time frame in order to seek a solution before specific commitments may be suspended, whether in full or in part, under the agreement. ${ }^{372}$ A role attributed to arbitration after suspension can also be considered, where necessary, as part of the dispute settlement provisions. ${ }^{373}$

\section{(iv) The European Neighbourhood and Partnership Policy}

The European Neighbourhood Policy ("ENP") was first outlined in a European Commission Communication on Wider Europe in 2003. ${ }^{374}$ The Communication was completed by a more detailed Strategy paper on

369. Council document 10491/1/09, Rev. 1, of 2 June 2009.

370. See also Case C-268/94, Portugal v. Council, 1996 E.C.R. I-6177.

371. Council of the European Union, Reflection Paper on Political Clauses in Agreements with Third Countries, Doc. 7008/09 (Feb. 27, 2009).

372. Id.

373. Commission Communication on Wider Europe-Neighbourhood: A New Framework for Relations with our Eastern and Southern Neighbours, COM (2003) 104 final (Mar. 11, 2003). E.g., Art. 96 of the EU Cotonou Agreement with African, Caribbean and Pacific countries, the mechanism laid down therein has been invoked in more than 19 cases since 1995. Council Decision 2005/95, art. 96, 2005 O.J. (L 209) 26 (EC).

374. Communication from the Commission to the Council and the European Parliament on Wider Europe-Neighbourhood: A New Framework for Relations with our Eastern and Southern Neighbours, COM (2003) 104 final (Mar. 11,2003), available at http://ec.europa.eu/world/enp/pdf/com03_104_en.pdf. 
European Neighbourhood Policy of May 2004. ${ }^{375}$ At present, the legal framework for planning and delivering EU assistance is laid down in Regulation 1638/2006, establishing a European Neighborhood and Partnership Instrument ("ENPI"). ${ }^{376}$ The ENPI applies to the partner countries listed in the Annex to the Regulation, which are Ukraine, Moldova, Belarus, Armenia, Azerbaijan, Georgia, Algeria, Egypt, Israel, Jordan, Lebanon, Libya, Morocco, Palestinian Authority, Syria, and Tunisia. Although Russia is a neighbor of the EU, Recital 11 of the Regulation explains that "the EU and Russia have decided to develop their specific strategic partnership through the creation of four common spaces" (these are Economic Freedoms, Security and Justice, External Security, Research, and Education). ${ }^{377}$ Multilaterally, the axes of the ENP are the Eastern Partnership ${ }^{378}$ and the Union for the Mediterranean ${ }^{379}$ through which the EU offers its neighbors a privileged relationship. The objectives of this relationship are stability, security, and prosperity, as a means to strengthen cooperation and expand these objectives "beyond the borders of the European Union."

The ENP goes beyond existing relationships to offer a deeper political relationship and economic integration with the EU. ${ }^{380}$ The level of ambition

375. Communication from the Commission on European Neighbourhood Policy Strategy Paper, COM (2004) 373 final (May 12, 2004), available at http://ec.europa.eu/world/enp/pdf/strategy/strategy paper_en.pdf. The genesis of the European Neighbourhood Policy can be traced several years earlier. For an exposition of such genesis, see Marise Cremona, The European Neighborhood Policy. More than a Partnership?, in Developments in EU External Relations Law 244, 246 (Marise Cremona ed., 2008); Marise Cremona, The European Neighbourhood Policy: Partnership, Security and the Rule of Law, WIDER Europe Policy Papers (2005); Marise Cremona, The European Neighbourhood Policy: Legal and Institutional Issues 1 (Ctr. on Democracy, Dev., and the Rule of Law, Stanford Inst. for Int'l Studies, Working Paper No. 25, 2004).

376. Council Regulation 1638/2006, 2006 O.J. (L 310) 1 (EC). Regulation 1638/2006 replaces Regulation 1488/96 supporting the Mediterranean non-member countries and territories (MEDA) (Council Regulation 1488/96, 1996 O.J. (L 189) 1 (EC)) and Regulation 99/2000 assisting Eastern Europe and Central Asia (TACIS) (Council Regulation 99/2000, 2000 O.J. (L 12) 1 (EC, EURATOM)).

377. 2006 O.J. (L 310/1) 2.

378. Joint Declaration 8435/09, of the Prague Eastern Partnership Summit, Presse 78 (May 7, 2009), available at $\mathrm{http} / /$ www.consilium.europa.eu/uedocs/cms_data/docs/pressdata/en/er/107589.pdf. The Eastern Partnership Prague Summit Declaration of 7 May 2009 also contains ample references to the rule of law. Joint Declaration 8435/09, at 78 .

379. The Summit Declaration of the Union for the Mediterranean of 13 July 2008 explicitly refers to the rule of law to which references in the context of counter-terrorism and more general references can be found in the Marseille Ministerial Declaration of 3-4 Nov. 2008. Joint Declaration 11794/08, of the Paris Summit for the Mediterranean, Presse 211 (July 13, 2008); Final Declaration 15187/08, on the Barcelona Process: Union for Mediterranean Ministerial Conference, Presse 314 (Nov. 3-4, 2008).

380. Presidency Conclusions, Brussels European Council, \ 57 (June 15-16, 2006), available at http://www.consilium.europa.eu/uedocs/cms_Data/docs/pressdata/en/ec/90111.pdf. 
of the relationship depends on the extent to which the common values are shared. The ENP is not an enlargement policy although it does not prejudge the future development of the relationship with the EU of the states involved. It offers "more than partnership and less than membership." 811 The chief elements of the ENP are the bilateral or multi-country programs, cross-border cooperation programs setting out strategies, and joint operational programs covering cooperation on programs for land borders and sea crossings ${ }^{382}$ These are in addition to ENP Action Programs and joint-cross border cooperation Plans agreed to by the EU and each partner, which are drawn up on the basis of the strategies contained in the country or multi-country programs. The Action Programs specify the objectives pursued, the fields of intervention, the expected results, the management procedures, and the total amount of financing planned. ${ }^{383}$ These Action Programs and joint cross-border cooperation Plans set out an agenda of political and economic reforms that include short and medium term priorities. Implementation of these Action Programs and Plans is jointly promoted and monitored through subcommittees established in the framework of the relevant agreement with each partner.

Although adopted in 2006, the ENPI Regulation 1638 does reflect the new mandate from Article 8 TEU (Lisbon) that the Neighborhood Policy of the Union is "founded on the values of the Union" as laid down in Article 2 TEU, which provides that the Union "is founded on the values of respect for human dignity, freedom, democracy, equality, the rule of law and respect for human rights." More specifically, with regard to the rule of law, Art. 2(d) of Regulation 1638/2006 provides that EU assistance shall be used to support measures within the area of cooperation aimed at "promoting the rule of law and good governance, including strengthening the effectiveness of public administration and the impartiality and effectiveness of the judiciary, and supporting the fight against corruption and fraud." The ENPI Regulation establishes a "privileged relationship" between the European Union and its neighbors, which is built on commitments to "common values" "including democracy, the rule of law, good governance and respect for human rights, and to the principles of market economy, free trade and sustainable development, and poverty reduction, ${ }^{384}$ pursuant to recital clause 4 of the

381. Romano Pradi, President of the European Comm'n, A Wider Europe-A Proximity Policy as the Key to Stability (Dec. 5-6, 2002).

382. Council Regulation 1638/2006, arts. 6, 7, 9, 12, 13, 2006 O.J. (L 310) (EC).

383. Id. at arts. 12,8 .

384. See also General Affairs and External Relations [GAER], Council Conclusions on European 
Preamble to Regulation 1638/2006. Article 1(3) of the Regulation specifies that these are values that the Union "seeks to promote ... in partner countries through dialogue and cooperation." These principles are not new. The Common Strategies adopted by the European Council in relation to Russia, Ukraine, and the Mediterranean in the late 1990s made explicit references to a strategic partnership based on "values and common interests," 385 and "foundations of shared values enshrined in the common heritage of European civilisation." $" 386$

In the case of the Mediterranean, the promotion of "core values" embraced by the EU and its Member States has been made a key goal of Union policy towards the region. ${ }^{387}$ The Preambles, both of the existing Partnership and Cooperation Agreements (PCAs) and of the EuroMediterranean Association Agreements (developed at present within the framework of the Union for the Mediterranean assembling the 27 EU Member States and 16 partner countries primarily from the Mediterranean ${ }^{388}$ ), contain a reference to "the common values that they share." ${ }^{899}$ In the case of the PCAs, the values constitute an essential element of the agreement so that a violation of the values constitutes a justification for suspension or denunciation of the agreements. In practice, a curious distinction has been made between the PCAs with Russia, Ukraine, and the Republic of Moldova on the one hand, and those PCAs concluded with Southern Caucasus on the other hand. The former include a paramount reference to the rule of law in the Preamble: "[c]onvinced of the paramount importance of the rule of law and respect for

Neighbourhood Policy (EC) No. 10189/04 (Presse 195) of 14 June 2004. The idea of shared values has been included in the ENP from the beginning; the European Council at Copenhagen in December 2002, for example, said that the "new dynamic" created by enlargement "presents an important opportunity to take forward relations with neighbouring countries based on shared political and economic values." Copenhagen European Council, Presidency Conclusions 15917/02, ๆף 22, 12 and 13 December 2002 (EU) (emphasis added).

385. Common Strategy 1999/887, of the European Council of 11 Dec. 1999 on Ukraine, 1999 O.J. (L 331) 1 .

386. Common Strategy 1999/414, of the European Union of 4 June 1999 on Russia, 1999 O.J. (L 157) 1 .

387. Common Strategy 2000/458, of the European Council of 19 June 2000 on the Mediterranean Region, 2000 O.J. (L 183) 6. The core values include "human rights, democracy, good governance, transparency and the rule of law." Id.

388. Joint Declaration 11794/08, supra note 379.

389. See, e.g., Partnership and Cooperation Agreement between the European Communities and their Member States, and Ukraine, 1998 O.J. (L 49) 3; Decision of the Council and the Commission 98/238, on the Conclusion of a Euro-Mediterranean Agreement Establishing an Association Between the European Communities and their Member States, of One Part, and the Republic of Tunisia, of the Other Part, 1998 O.J. (L 97) 2. 
human rights, particularly those of minorities, the establishment of a multiparty system with free and democratic elections and economic liberalization aimed at setting up a market economy. ..." However, the rule of law is neither explicitly included among the "essential elements" in Article $2,{ }^{390}$ nor mentioned in Article 6 on political dialogue, unlike democracy, human rights, and minority rights. ${ }^{391}$ The PCAs with the Southern Caucasus countries, by contrast, in addition to a mention of the rule of law in the Preamble (again, it is not among the "essential elements"), include among the areas of cooperation:

[A]1l questions relevant to the establishment or reinforcement of democratic institutions, including those required in order to strengthen the rule of law, and the protection of human rights and fundamental freedoms according to international law and OSCE principles. This cooperation shall take the form of technical assistance programmes intended to assist, inter alia, in the drafting of relevant legislation and regulations; the implementation of such legislation; the functioning of the judiciary; the role of the State in questions of justice; and the operation of the electoral system $\ldots{ }^{392}$

The relationship with Armenia, Azerbaijan, Belarus, Georgia, the Republic of Moldova, and Ukraine has been given further impetus within the framework of the "Eastern Partnership," which was launched at the EU Prague Summit on May 7, 2009. The Eastern Partnership envisages further economic integration (by means of the conclusion of new Association Agreements) and an acceleration of political association by strengthening the promotion of

390. See, e.g., Partnership and Cooperation Agreement between the European Communities and their Member States, and Ukraine, 1998 O.J. (L 49) 3; and Decision of the Council and the Commission 98/238, on the Conclusion of a Euro-Mediterranean Agreement Establishing an Association Between the European Communities and their Member States, of One Part, and the Republic of Tunisia, of the Other Part, 1998 O.J. (L 97) 2.

391. See 1999 O.J. (L49); Benita Ferrero-Walker, European Comm'r for External Relations and European Neighbourhood Policy, European Strategies for Promoting Democracy in Post-Communist Countries (Jan. 20, 2006) ("We understand that democracy can never be improved from the outside; genuine democratic transition must always come from within.").

392. Council and Commission Decision 1999/515, on the Conclusion of the Partnership and Cooperation Agreement Between the European Communities and their Member States, of the One Part, and Georgia, of the Other Part, art. 71, 1999 O.J. (L 205) 21. The PCAs with Armenia and Azerbaijan contain similar provisions. There is also a provision on cooperation with respect to prevention of illegal activities including corruption. Id. at arts. 72, 22. 
democracy and good governance. ${ }^{393}$ Belarus, Libya, and Syria do not yet have Association Agreements in force.

The provisions on shared values constitute a political conditionality so that the level of ambition of each relationship depends on the extent to which the common values are shared. The Commission's Strategy Paper of May 2004 makes clear the link between progress in relations with the EU and progress in implementing agreed targets, including commitment to the rule of law:

The Union is founded on the values of respect for human dignity, liberty, democracy, equality, the rule of law and respect for human rights. . . . The European Neighbourhood policy seeks to promote commitment to shared values. The extent to which neighbouring countries implement commitments in practice varies and there is considerable scope for improvement. Effective implementation of such commitments is an essential element in the EU's relations with partners. The level of the EU's ambition in developing links with each partner through the ENP will take into account the extent to which common values are effectively shared. The Action Plans will contain a number of priorities intended to strengthen commitment to these values. These include strengthening democracy and the rule of law, the reform of the judiciary and the fight against corruption and organised crime . . . ${ }^{394}$

The political conditionality of the rule of law and other shared values is also identified in the priorities established in the Action Plans.

The level of the EU's ambition in developing links with each partner through the ENP will take into account the extent to which common values are effectively shared. The Action Plans will contain a number of priorities intended to strengthen commitment to these values. These include strengthening democracy and the rule of law, the reform of the judiciary and the fight against corruption and organised crime; respect of human rights and fundamental freedoms, including freedom of media and expression, rights of minorities and children, gender equality, trade union rights and other core labour standards, and fight against the practice of torture and prevention of ill-treatment; support for the development of civil society; and co-operation with the International Criminal Court. Commitments will also be sought to certain essential aspects of the EU's external action, including, in particular, the fight against terrorism and the proliferation of weapons of mass destruction, as well as abidance by international law and efforts to achieve conflict resolution. ${ }^{395}$

393. See Joint Declaration $8435 / 09$, supra note 378. See also Press Release, Council of the European Union, Conclusions on Eastern Partnership, (Oct. 25, 2010), available at http://www.consilium.europa.eu/ uedocs/cms_data/docs/pressdata/EN/foraff/117327.pdf.

394. Communication from the Commission European Neighbourhood Policy Strategy Paper, supra note 375 , at $12-13$.

395. Id. at 13 . 
Above all, the shared values (as well as prosperity and stability) are included in the context of security as a paramount purpose of the ENP relationship, which will enhance the security of the Union itself. As it is emphasized in the European Security Strategy (“A Secure Europe in a Better World" adopted by the Brussels European Council in December 2003):

It is in the European interest that countries on our borders are well-governed. Neighbours who are engaged in violent conflict, weak states where organized crime flourishes, dysfunctional societies or exploding population growth on its borders all pose problems for Europe. The integration of acceding states increases our security but also brings the EU closer to troubled areas. Our task is to promote a ring of wellgoverned countries to the East of the European Union and on the borders of the Mediterranean with whom we can enjoy close and cooperative relations. ${ }^{396}$

The emphasis is thus placed on partnership, interdependence, avoiding the creation of new dividing lines, and shared values which create a "common project." ${ }^{397}$ The implications of the rule of law for the EU's own security policies involve the alignment of the EU neighbors to EU policies on sensitive issues such as terrorism, immigration, and border issues. ${ }^{398}$ Thus, the EU is concerned with the potential for breakdown in the rule of law and in law and order and stability within its neighbors, not just as an uninvolved observer or aid donor (the Union links the gains for the neighbor states in the ENPI to increased EU financial assistance, participation in EU programs, assistance in alignment to EU legal and regulatory norms; "a stake in the biggest Single Market in the world" ${ }^{399}$ ), but as a neighbor whose members are likely to be directly affected by the fallout from civil insecurity.

Finally, the success of the security objective in the ENP "depends on achieving stability and prosperity," ${ }^{400}$ which means promoting stability

396. Council of the European Union, A Secure Europe in a Better World, Doc. 10881/03, at 7-8 (Dec. 12, 2003), available at http://www.consilium.europa.eu/uedocs/cmsUpload/78367.pdf.

397. It should be noted that, on a wider scale, the Lisbon OSCE Declaration states that "[o]ur approach is one of co-operative security based on democracy, respect for human rights, fundamental freedoms and the rule of law, market economy and social justice. It excludes any quest for domination. It implies mutual confidence and the peaceful settlement of disputes." Organization for Security and Cooperation in Europe [OSCE], Libson Declaration on a Common and Comprehensive Security Model for Europe for the Twenty-First Century 93 , OSCE Doc. S/1/96 (Dec. 3, 1996).

398. See Elspeth Guild, International Terrorism and EU Immigration, Asylum and Borders Policy: The Unexpected Victims of 11 September 2001, 8 European Foreign Aff. Rev. 331 (2003).

399. Judith Kelley, New Wine in Old Wineskins: Promoting Political Reforms through the New European Neighbourhood Policy, 44 J. Соммоn Mкт. Stud. 29 (2006).

400. Marise Cremona, The European Neighbourhood Policy as a Framework for Modernization, in European Integration without EU Membership: Models, Experiences, Perspectives 7 (European University Institute, Working Papers 2009/10, 2009), available at http://cadmus.eui.eu/bitstream/handle/ 
conceived also as a pre-condition for the democratization, rule of law, good governance, political reform, ${ }^{401}$ and economic development. In its March 2003 paper on the Wider Europe, the Commission stressed this link as follows:

\begin{abstract}
Democracy, pluralism, respect for human rights, civil liberties, the rule of law and core labour standards are all essential prerequisites for political stability, as well as for peaceful and sustained social and economic development. . . . A political, regulatory and trading framework, which enhances economic stability and institutionalises the rule of law, will increase our neighbours' attractiveness to investors and reduce their vulnerability to external shocks. ${ }^{402}$
\end{abstract}

In summary, the ENP is a form of EU relationship lying between enlargement and the general foreign policy. Although the ENP is not an enlargement policy, it does not prejudge the issue of enlargement. Within the ENP, the rule of law is an important element of conditionality in the progress of the EU's policy with its neighbors. In its Work Program 2011, the Commission indicated that over the past five years the ENP "has shown ... the EU's ability to project its values and principles and to contribute to political stability and economic development in its neighbourhood. ... The Commission will continue to help to deepen the EU's special relationship with these neighbours. ..." ${ }^{403}$ The Commission intends to make further proposals in 2011 for the further development of the EU bilateral and multilateral partnership in its Eastern Partnership and Union for the Mediterranean dimensions.

\title{
(v) Pre-accession assistance
}

The principles applied in the context of the ENP also apply to the assistance provided by the EU to European states which may one day become members of the Union. Compliance with the rule of law has also been a condition within the pre-accession strategy for the enlargement of the EU (where the key objectives are stability, prosperity, security of the Union's borders and shared values) since, as we have seen, Article 49 of the (Lisbon)

\footnotetext{
1814/11294/MWP_2009_10.pdf?sequence=1.

401. See id. Thus, the stability of national institutions is a first priority in the ENPI Action Plan for Ukraine.

402. Commission Communication on Wider Europe-Neighbourhood: A New Framework for Relations with our Eastern and Southern Neighbours, at 7, 9, COM (2003) 104 final (Mar. 11, 2003).

403. See Communication from the Commission to the European Parliament, the Council, the European Economic and Social Committee and the Committee of the Region, at 9, COM (2010) 623 final (Oct. 27, 2010).
} 
TEU makes it a condition for any applicant European state to respect the rule of law and other values of the EU pursuant to Article 2 of the (Lisbon) TEU. At present, the pre-accession strategy takes place within the framework of Council Regulation 1085/2006. This establishes an Instrument for PreAccession Assistance ("IPA"). ${ }^{404}$ The European Union assistance is based on a crucial distinction between two groups of countries: candidates countries (Croatia, Turkey, and the former Yugoslav Republic of Macedonia and Iceland $^{405}$ which was granted candidate status in July 2010), and potential candidates (Albania, Bosnia, Montenegro, Serbia including Kosovo, as defined in UNSC Resolution $\left.1244^{406}\right)$.

(vi) EU development and economic, financial and technical assistance policies

Pursuant to the Treaties, the policies of the EU relating to development cooperation and economic, financial, and technical assistance to third countries have to be consistent with and take place within the framework of the rule of law as an objective. The promotion, development, and consolidation of the rule of law and democracy, and of respect for human rights and fundamental freedoms have constituted "a prime objective of the EU development policy and economic, financial and technical cooperation with third countries." ${ }^{407}$ The Treaty of Lisbon has reinforced the objective of the rule of law in these fields since the Union's policy in those fields "shall be conducted within the framework of the (general) principles and objectives of the Union's external action." This is included in Article 21(b) of the (Lisbon) TEU, which provides for the consolidation of and support for democracy, the

404. 2006 O.J. (L 210) 82. IPA Regulation replaced previous enlargement programs such as Phare, SAPARD, ISPA and CARDS.

405. Council Regulation 540/2010, 2010 O.J. (L 158) 7 (EU). In 1999 the European Commission had envisaged an articulation between three groups: first, those European countries which are eligible for membership, but either do not at present which to accede or are at the initial stages of submission of their candidacy (such as Switzerland, Iceland and Norway); second, those European countries which may be seen as "potential candidates" (Thessaloniki European Council of June 2003), which may desire membership but which do not yet meet the criteria and may not yet have made a formal application (this includes certain countries of the Western Balkans-Montenegro, Albania, and Serbia have applied); and third, those countries which are already or will become "near neighbours" of the enlarged Union, including Russia, Ukraine and the southern states, especially those of the Maghreb (Algeria, Morocco, Tunisia).

406. 2006 O.J. (L 210) 82, 92-93 (annexes I and II of Regulation No. 1085/2006).

407. Communication from the Commission to the Council and the European Parliament on the European Union's Role in Promoting Human Rights and Democratisation in Third Countries, COM (2001) 252 final (May 8, 2001). 
rule of law, human rights, and the principle of international law pursuant to Article 208 and 212(1) TFEU. ${ }^{408}$

For the current period 2007-2013, EU development cooperation is funded within the legal framework established by Regulation 1905/2006. That establishes a financing instrument for development cooperation ${ }^{409}$ and covers all countries not eligible under ENPI or PCA. The Member States' development cooperation assistance is funded inter alia by the 10th European Development Fund, which is the main instrument for providing development aid to the African, Caribbean, and Pacific (ACP) countries and the overseas countries and territories. The Fund is governed by the ACP-EU Partnership Agreement (signed in 2000 and revised in 2005 and in 2010) ${ }^{410}$ and the amended Overseas Association Decision. ${ }^{411}$ The EU's action on the rule of law and development is based on the European Consensus on Development, signed on December 20, 2005, whereby the EU Member States, the Council, the European Parliament, and the Commission agreed to a common EU vision of development. ${ }^{412}$ The Consensus identifies a development based on the EU's "democratic values," including the rule of law, goals, principles, and commitments to be implemented in development policies, in particular in reducing poverty and in the alignment of EU aid with the national strategies and procedures of developing countries. The Consensus also includes a section on "Policy Coherence for Development ("PCD")" 413 to be applied in many areas (trade, environment, climate change, security, agriculture, fisheries, social dimension of globalization, employment and decent work, migration, research, information, transport, and energy), with the rule of law, democracy, good governance, and human rights among the cross-cutting issues identified. ${ }^{414}$ The EU and its Member States together constitute the

408. 2002 O.J. (325) 1, 109-11 (this objective was present before the entry into force of the Treaty of Lisbon: "Community policy in this area shall contribute to the general objective of developing and consolidating democracy and the rule of law, and to that of respecting human rights and fundamental freedoms" (formerly Arts. 177(2) and 181a(1) of the TEC)).

409. 2006 O.J. (L 378) 41. This instrument replaces thirteen regulations including Council Regulation 443/92, 1992 O.J. (L 51) 1 on the provision of assistance to developing countries in Latin American and Asian countries (ALA).

410. 2000 O.J. (L 317) 3, amended by 2005 O.J. (L 209) 27, and by 2010 O.J. (L 287) 3.

411. 2002 O.J. (L 64) 39; 2001 O.J. (L 324) 1; 2001 O.J. (L 314) 1.

412. 2006 O.J. (C 46) 1.

413. Communication from the Commission to the Council and the European Parliament on the European Union's Role in Promoting Human Rights and Democratisation in Third Countries, supra note 407.

414. Joint Statement on European Union Development Policy: the European Consensus, 2006 O.J. (C 46) I, paras. 35-38. 
biggest providers of development aid in the world, collectively spending around 49 billion Euro on development assistance in 2009. ${ }^{415}$

The economic, financial, and technical cooperation assistance of the European Union is provided mainly through Regulation 1934/2006 of December 21, 2006. That establishes a financing instrument for cooperation with industrialized and other high-income countries and territories. The assistance is given through multi-annual cooperation programs pursuant to Article 5 and annual action programs pursuant to Article 6, provided that the areas of cooperation are implemented with full respect for the principles of "liberty, democracy, respect for human rights and fundamental freedom and the rule of law." $" 416$

In addition, two horizontal legal instruments are significant. First, Regulation 1717/2006, establishing an Instrument for Stability ${ }^{417}$ creates a development and financial assistance instrument aiming to contribute to stability in situations of crisis and emerging crisis, and in the face of specific global and trans-regional threats. The Regulation provides that technical and financial assistance shall cover:

\begin{abstract}
[S] upport for the development of democratic, pluralistic state institutions, including measures to enhance the role of women in such institutions, effective civilian administration and related legal frameworks at national and local level, an independent judiciary, good governance and law and order, including non-military technical cooperation to strengthen overall civilian control, and oversight over the security system and measures to strengthen the capacity of law enforcement and judicial authorities involved in the fight against the illicit trafficking of people, drugs, firearms and explosive materials. ${ }^{418}$
\end{abstract}

The second instrument is Regulation 1889/2006 "establishing a financing instrument for the promotion of democracy and human rights worldwide,"419 which provides:

This Regulation establishes a European Instrument for Democracy and Human Rights under which the [EU] shall provide assistance, within the framework of the $[\mathrm{EU}]$ 's policy on development cooperation, and economic, financial and technical

415. A Twelve-Point EU Action Plan in Support of the Millennium Development Goals, at 5, COM (2010) 159 final (Apr. 21, 2010), available at http://ec.europa.eu/development/icenter/repository/ COMM_COM_2010_0159_MDG_EN.PDF.

416. Id. at 46- $49 ; 2006$ O.J. (L 405) 41.

417. Commission Regulation 1717/2006, 2006 O.J. (L 327) 1 (EC) (establishing an Instrument for Stability).

418. Id. at 3 (Art. $3(2)(\mathrm{c}))$.

419. Commission Regulation 1889/2006, 2006 O.J. (L 386) 1 (EC). 
cooperation with third countries, consistent with the European Union's foreign policy as a whole, contributing to the development and consolidation of democracy and the rule of law, and of respect for all human rights and fundamental freedoms. ${ }^{420}$

This Regulation allows for assistance which is independent of the consent of third country governments and other public authorities and codifies a series of piecemeal legislation provisions which contributed to the general objective of consolidating democracy, the rule of law, and respect for human rights such as Regulations 975/1999 and 976/1999. ${ }^{421}$

\section{(vii) The Rule of Law in the Common Foreign and Security Policy of the} Union

As with the rest of the external action of the Union, the Common Foreign and Security Policy of the Union ("CFSP") must respect and pursue the general objectives of the rule of law, democracy, and human rights. ${ }^{422}$

The starting point is the European Security Strategy, adopted by the European Council in 2003, according to which "[t]he development of a stronger international society, well functioning international institutions and a rule-based international order is our objective. We are committed to upholding and developing International Law. The fundamental framework for

420. Id. at 4 (Art. 1(1)).

421. Council Regulation 976/1999, 1999 O.J. (L 120) 8 (EC) ("laying down the requirements for the implementation of Community operations, other than those of development cooperation, which, within the framework of Community cooperation policy, contribute to the general objective of developing and consolidating democracy and the rule of law and to that of respecting human rights and fundamental freedoms in third countries"); Council Regulation 975/1999, 1999 O.J. (L 120) 1 (EC) ("laying down the requirements for the implementation of development cooperation operations which contribute to the general objective of developing and consolidating democracy and the rule of law and to that of respecting human rights and fundamental freedoms"). See also Council Common Position (EC) 98/350/CFSP of 25 May 1998, 1998 O.J. (L 158) 1 ("concerning human rights, democratic principles, the rule of law and good governance in Africa").

422. 1992 O.J. (C 191) 1, 58 (Art. 11(1), ex Art. J.1 of the TEU provides that the objectives of the CFSP include "safeguard[ing] the common values, fundamental interests and independence of the Union ... in accordance with the principles of the United Nations Charter as well as the principles of the Helsinki Final Act and the objectives of the Paris Charter," and "develop[ing] and consolidat[ing] democracy and the rule of law, and respect for human rights and fundamental freedoms"). These objectives have been considerably reinforced under the Treaty of Lisbon; see 2008 O.J. (C 115) 15, 17 (Art. 3(5) of the Treaty on European Union (TEU) provides that the Union shall contribute to "the protection of human rights, in particular the rights of the child, as well as to the strict observance and the development of international law, including respect for the principles of the United Nations Charter"); see also 2008 O.J. (115) 15, 35-36 (strengthening further these objectives with the guiding principle of the rule of law laid down in the general provisions of Art. 21 TEU). 
international relations is the United Nations Charter." ${ }^{\text {423 }}$ The Union considers it "a condition of a rule-based international order that law evolves in response to developments such as proliferation, terrorism, and global warming. [It has] an interest in further developing existing institutions such as the World Trade Organisation and in supporting new ones such as the International Criminal Court," and in "[c]ontributing to better governance through assistance programmes, conditionality and targeted trade measures.... A world seen as offering justice and opportunity for everyone will be more secure for the European Union and its citizens. ${ }^{\prime 24}$ With regard to policy implications, the EU acknowledges that "if we are to make a contribution that matches our potential, we need to be more active, more coherent and more capable. And we need to work with others." ${ }^{25}$

Having identified international conflicts (Middle East), state failure, terrorism, organized crime, nuclear proliferation, global warming, environmental degradation, financial turmoil, and globalization among the threats and challenges that the Union is facing, the 2008 Report on the Implementation of the European Security Strategy entitled "Providing Security in a Changing World," states that

\begin{abstract}
[I]t is important that countries abide by the fundamental principles of the UN Charter and OSCE principles and commitments. We must be clear that respect for the sovereignty, independence and territorial integrity of states and the peaceful settlement of disputes are not negotiable. Threat or use of military force cannot be allowed to solve territorial issues - anywhere. At a global level, Europe must lead a renewal of the multilateral order. The UN stands at the apex of the international system. Everything the EU has done in the field of security has been linked to UN objectives. We have a unique moment to renew multilateralism, working with the United States and with our partners around the world. For Europe, the transatlantic partnership remains an irreplaceable foundation, based on shared history and responsibilities. The EU and NATO must deepen their strategic partnership for better co-operation in crisis management. ${ }^{426}$
\end{abstract}

Generally the EU's external action on the rule of law, within the framework of the CFSP, distinguishes between the EU's action ensuring the promotion

423. European Council, European Security Strategy, Doc. 15895/03 PESC 787, at 11, available at http://www.consilium.europa.eu/uedocs/cmsUpload/78367.pdf.

424. Id. at 10 .

425. Id. at 11 .

426. Council of the European Union, Report on the Implementation of the European Security Strategy: Providing Security in a Changing World, Doc. S407/08, at 2 (Dec. 11, 2008), available at http://www.euun.europa.eu/documents/en/081211_EU\%20Security\%20 Strategy.pdf. 
of the rule of law by third parties as an objective, and the EU's action ensuring respect for the rule of law by the EU itself.

With regard to the promotion of the rule of law by third parties as an objective of the EU, the EU Council has adopted Guidelines on Promoting Compliance with International Humanitarian Law $\left(2005,{ }^{427}\right.$ revised in $2009^{428}$ ) as well as various guidelines on specific human rights issues, including the death penalty, human rights defenders, and torture. ${ }^{429}$ In several cases, the EU has adopted sanctions (restrictive measures), in response inter alia to violations of human rights and the rule of law in a third country. These sanctions have taken the form of interruption of economic relations with a third country, arms embargoes, economic and financial sanctions, freezing of assets, restrictions on admission (visa or travel ban) and targeted (smart) sanctions against specific persons, groups, and entities responsible for terrorist acts. ${ }^{430}$ The EU has also adopted various measures in support of the international criminal tribunals and national prosecution and reconciliation mechanisms. These measures include the EU Common Position on the International Criminal Court. ${ }^{431}$ the cooperation agreement with that Court, ${ }^{432}$ guidelines on agreements adopted pursuant to Article 98 of the ICC Statute (which aim to exempt persons from the Court's jurisdiction) that seek to limit the scope of those agreements to only what is deemed to be in accordance with the ICC Statute, ${ }^{433}$ and sanctions against persons indicted by the ICTY including the freezing of funds ${ }^{434}$ and support for reconciliation and transitional justice processes. It should also be recalled that with regard to non-CFSP competences, Article 3(2)(d) of the Instrument for Stability

427. 2005 O.J. (C 327) 4.

428. 2009 O.J. (C 303) 12.

429. See Council of the European Union, Guidelines on Human Rights, http://www.consilium .europa.eu/showpage.aspx?id=1681 \&lang=EN.

430. See Council of the European Union, Restrictive Measures-EU Best Practices for the Effective Implementation of Restrictive Measures, Doc. 11679/07 (July 9, 2007) (an update may be found in the website http://ec.europa.eu/external_relations/cfsp/sanctions/docs/measures_en. pdf.); Council of the European Union, Basic Principles on the Use of Restrictive Measures (Sanctions), Doc. 10198/1/04 REV 1 (June 7, 2004), available at http://register.consilium.europa.eu/pdf/en/04/st10/st10198-re01.en04.pdf; Council document 5579/03 of 8 Dec. 2003.

431. Council Common Position (EU) 2003/444/CFSP of 16 June 2003, 2003 O.J. (L 150) 67.

432. Council of the European Union, Agreement between the International Criminal Court and the European Union on Cooperation and Assistance, Doc. 14298/05 (Dec. 6, 2005), available at http://register.consilium.eu.int/pdf/en/05/st14/st14298.en05.pdf.

433. Council of the European Union, General Affairs and External Relations, Doc. 12134/02 (Presse 279), at 9-10 (Sept. 30, 2002), available at http://www.consilium.europa.eu/uedocs/cms_data/docs/ pressdata/en/gena/72321.pdf.

434. Council Common Position (EU) 2004/694/CFSP, 2004 O.J. (L 315) 52 (as amended). 
provides for the EU to "support for international criminal tribunals and ad hoc national tribunals, truth and reconciliation commissions, and mechanisms for the legal settlement of human rights claims and the assertion and adjudication of property rights, established in accordance with international human rights and rule of law standards," thus ensuring that the external action of the EU is consistent as a whole. ${ }^{435}$

With regard to respect for the rule of law by the EU itself in the conduct of its external relations under CFSP, the EU has to comply with the principle of conferred powers according to which "the Union shall act only within the limits of the competences conferred upon it by the Member States" pursuant to Article 5(2) TEU. ${ }^{436}$ And the principle of solidarity, according to which the conduct, definition, and implementation of policies are based on the development of a "mutual political solidarity among Member States, the identification of questions of general interest and the achievement of an everincreasing degree of convergence of Member States' actions" pursuant to Article 24 paragraph 2 TEU. ${ }^{437}$ Therefore, not surprisingly, the Treaties regulate the EU's external relations competences in quite some detail even though the EU's competences in the rule of law are very wide. The EU's action under the CFSP is subject only to limited control by the Court of Justice of the European Union. The Court is not competent on CFSP issues, but it has jurisdiction over EU sanctions involving physical and legal persons (e.g., in the fight against terrorism) and it is competent to verify whether CFSP decisions encroach on other EU competences (non-CFSP competences) and vice versa pursuant to Articles 24 and 40 (Lisbon) TEU and Article 275 TFEU. Finally, respect by the EU for human rights in external relations is an ongoing challenge involving a balancing of the rule of law; human rights, and security (e.g., counter-terrorism sanctions). Questions relating to the interaction between legal orders and the rule of law at each of these levels, and between them (e.g. the Kadi judgment, which while criticized by some from an international law perspective), have led to improvements with regard to due process in the elaboration, adoption, and implementation of lists of terrorists by the UN Security Council. ${ }^{438}$

The EU's external action within its crisis management operations is of particular relevance for the purpose of the rule of law. These crisis management operations and missions are carried out by the Union in third

435. Commission Regulation 1717/2006, 2006 O.J. (L 327) 1, 3 (EC).

436. 2008 O.J. (C 115) 13, 18.

437. Id. at 30 .

438. See Chagla, supra note 300. 
countries pursuant to its Common Security and Defence Policy (CSDP). A distinction is made between the civilian aspects and the military aspects of the crisis management operations of the EU. The record is quite successful, since after being launched as the European Security and Defence Policy (ESDP) in 1999, the Common Security and Defence Policy (CSDP), referred to in the TEU (Lisbon), has developed rapidly. ${ }^{439}$ Also in the period from January 1 , 2003 until December 31, 2009, some 22 crisis management operations have been launched, including 6 military operations, 15 civilian operations, and one mixed civil-military operation. ${ }^{440}$ The most recent operation being EUFOR Libya, which had not been launched yet.

\section{(a) The Rule of Law in EU Civilian Crisis Management Operations}

The strengthening of the rule of law was identified in the year 2000 by the Feira European Council as one priority area for targeting civilian aspects of crisis management (the area most specifically concerned was assistance for the re-establishment of a judicial and penal systems). ${ }^{441}$ It marked out the possibility of providing up to 200 judges, prosecutors, and other legal experts. Concrete targets in the field of rule of law were set in the Göteborg European Council in 2001 in order to ensure a complete and functioning criminal justice process in EU operations in which international police perform an executive role. For the purpose of EU civilian crisis management operations, Member

439. See, e.g., European Security and Defence Policy: The First Ten Years (1999-2009) (Giovanni Grevi et al. eds., 2009), available at http://www.iss.europa.eu/uploads/media/ESDP_10-web.pdf; European Security Law (M. Trybus \& N. White eds., Oxford Univ. Press 2007); FrederiK Naert, International Law Aspects of the EU's Security and Defence Policy, with a Particular Focus on the Law of Armed Conflict and Human Rights (Intersentia 2010); Martin Trybus, European Union Law and Defence Integration (Hart Publishing 2005); The European Union and International Crisis Management: Legal and Policy Aspects (Steven Blockmans ed., T.M.C. Asser Press 2008); see generally EU Common Security and Defence Policy, Consilium, http://www.consilium .europa.eu/showPage. asp ? $\mathrm{id}=261$ \&lang $=\mathrm{EN} \&$ mode $=\mathrm{g}$.

440. Council Decision 2011/210/CFSP of 1 Apr. 2011 on the European Union, military operation in support of humanitarian assistance in Libya, 2011 OJ (L. 89) 17. See, e.g., NAERT, supra note 439, at 97-191; European SeCurity LAw, supra note 439, at 61-101. The reader may find a detailed list of EU operations on the Council's website: http://www.consilium.europa.eu/cms3_fo/showPage.asp?id=268\&lang $=\mathrm{EN} \&$ mode $=\mathrm{g}$. The number depends to some extent on how one counts them. This number excludes European Community or Union missions launched before 1999, which would probably qualify as crisis management operations today. In addition, the 25 January 2010 Foreign Affairs Council decided to set up a military mission to contribute to training of Somali security forces and to set up a cell in Brussels, EUCO Haiti, to coordinate contributions by Member States of military and security assets to meet needs in Haiti following the earthquake there.

441. Presidency Conclusions, Santa Maria da Feira European Council, Annex I, III, Appendix 3, II (June 19-20, 2000). 
States of the EU were requested to develop their capacity to deploy officials to local public prosecution, courts, and detention activities and, on a voluntary basis, to be able to contribute by 2003 , up to 200 officials adequately prepared, (including prosecutors, judges, correctional officers, and police rapid deployment units). They were also requested to be able to contribute to fact-finding missions made up of officials with broad knowledge in the field of rule of law, enabling an early planning of rule of law support, which could be deployed within 30 days. ${ }^{42}$ The Göteborg European Council stressed that rule of law capabilities were meant both to enable the EU to respond to requests from an international lead organization more effectively, and to carry out autonomous missions. These EU missions could be tasked with strengthening local institutions; and rule of law missions could also be undertaken without a police component. Furthermore, with regard to any given mission, subsequent hand-over to local ownership would be considered essential. ${ }^{443}$ Indeed, at a May 16, 2002 a senior official level capabilities commitment conference, Member States made, on a voluntary basis, commitments to build up the EU rule of law capabilities for crisis management by 2003 that exceeded the above-mentioned numeric targets. ${ }^{444}$ Finally, the Göteborg European Council described two generic concepts of rule of law missions. The first comprises of "missions strengthening the rule of law," in which "personnel in the field of rule of law are deployed essentially to educate, train, monitor and advise with the aim of bringing the local legal system up to international standards, ${ }^{, 445}$ in particular in the field of human rights. The second comprises of "missions aiming at substitution for local judiciary/legal system," in which "personnel in the field of rule of law are deployed to carry out executive functions, notably where local structures are failing (or do not exist), to consolidate the rule of law in a crisis situation and thereby restoring public order and security." ${ }^{446}$

442. Presidency Conclusions, Göteborg European Council, ๆฯ 47-52 (June 15-16, 2001), available at http://ec.europa.eu/governance/impact/background/docs/goteborg_concl_en.pdf; Council of the European Union, Presidency Report to the Goteborg European Council on European Security and Defence Policy, Doc. 9526/1/01 REV 1 (June 11, 2001).

443. Id. See also Council of the European Union, Comprehensive EU Concept for Missions in the Field of Rule of Law in Crisis Management, Including Annexes, at 3-4, Doc. 14513/02 (Nov. 19, 2002). 444. The ensuing declaration was annexed as Annex V to the Seville European Council. Presidency Conclusions, Seville European Council, at 9 ๆ 6-7 (Oct. 24, 2002), available at http://www.consilium .europa.eu/ueDocs/cms_Data/docs/pressdata/en/ec/72638.pdf.

445. UN, OSCE and Council of Europe standards will be particularly important. Council of the European Union, supra note 443, at 4.

446. Council of The European Union, supra note 443, 4-5. 
Of particular importance was the Comprehensive EU Concept for Missions in the Field of the Rule of Law in Crisis Management, which was endorsed by the Council Committee for Civilian Aspects of Crisis Management (CIVCOM) and noted by the EU Political and Security Committee (PSC) on May 26, 2003 (Council Doc. 9792/03). The Comprehensive EU Concept stresses that in most instances, particularly when a police component has been deployed, "the primary focus of the EU's efforts in the field of rule of law will be criminal procedure." However, the possibility of a rule of law mission dealing with civil law and administrative law aspects (for example family law, property, contracts, customs, and taxation) was also contemplated. The Concept adds a court system that commands the confidence of all and that will enforce obligations as a fundamental element of the EU mission. A particular feature of the EU is that EU personnel in the field of rule of law come from different legal systems. This diversity is a qualitative asset for the EU. ${ }^{447}$

The Comprehensive EU Concept also emphasizes that rule of law missions will have to be adapted "to the specific circumstances they will face in the mission area." ${ }^{448}$ For that purpose, assessments and, where appropriate, EU fact-finding missions will have to be carried out. ${ }^{449}$ "The composition of a fact-finding mission should be decided on a case-by-case basis, taking into account the ad hoc nature of fact-finding missions and the varying degrees of complexity of situations to be addressed." ${ }^{, 50}$

The Council of the European Union makes decisions on launching a rule of law mission in accordance with the Treaty and the established procedures described in the Crisis Management Procedures. The objectives of the mission are described in a mission statement accompanying the decision of the Council. The aim is to provide "for complete and sustainable judiciary and penitentiary systems under local ownership and meeting rule of law and human rights standards in the mission area and to improve these systems' capacities in accordance with the demands of a democratic society." ${ }^{.451}$ In principle, local law is applied, and when this is impossible, "recourse might be made to an interim legal framework to be elaborated within the framework

447. Id. at 7 .

448. $I d$.

449. Id. at 7-8. For that purpose a non-exhaustive check-list is provided in Annex 1 to the Comprehensive Concept which supplements those listed in Section D of the Annex to the general guidelines on fact-finding missions contained in Doc. 15048/01.

450. Id. at 10 .

451. Id. 
of the UN." ${ }^{{ }^{4} 2}$ The objective of a rule of law mission will be achieved throughout different phases (normally comprising an activation phase, a development phase, and a consolidation phase). ${ }^{453}$

The EU considers the participation of non-EU states in its civilian operations to be of paramount importance. Indeed, "the EU could lead a mission that includes EU components or also contributions from other international organizations or third states. ${ }^{" 454}$ The involvement of third states includes the conclusion of participation agreements based on model agreements adopted by the Council in the form of "Framework Participation Agreement" (FPA) or "Model Participation Agreement" (MPA). ${ }^{455}$ Alternatively, the EU could provide a rule of law component to a mission led by another organization. ${ }^{456}$ The EU draws on the experience of international organizations, in particular the UN, OSCE, and Council of Europe. The modalities for potential contributions of non-governmental organizations and non-state experts are delineated in Annex IV to the EU Comprehensive Concept. The EU also recognizes that "the success of a rule of law mission lies to a large extent in the capacity and readiness of local authorities to be fully involved from the beginning in the achievement of the [mission's] objectives." ${ }^{457}$ A "lessons learned" process is also regularly carried out. ${ }^{458}$

In principle, the EU does not launch a rule of law operation or mission unless the decision of the Council is based on and complies with international law, either pursuant to a resolution of the UN Security Council under Chapter VII of the UN Charter, following an invitation of the host country, or

452. Id. at 11 ("In this context, it is recalled that the EU has offered to the UN High Commission for Human Rights a set of draft guidelines as an initial contribution to the work undertaken within the UN. It is also recalled that the European Union co-funded a 2-year project presented by the office of the UN High Commissioner for Human Rights entitled 'Restoring the rule of law: supporting rights—sensitive transitional justice arrangements in post-conflict and post-crisis countries."').

453. Council of the European Union, supra note 443, at 12-13 (explaining the different phases of a mission).

454. Id. at 13-15 ("It has been agreed to further develop modalities for contributions of non-EU states to EU civilian crisis management operations, which could include rule of law missions." These modalities, which include the conclusion by the EU of participation agreements with participating non-EU states which are based on a model agreement that has been concluded by the Council, are of relevance to EU crisis management as a whole; "suitable arrangements should therefore be elaborated at an early stage in order to ensure coherence and co-ordination both at the political/strategic level as well as in the field.").

455. See, e.g., the Agreement between the European Union and the Republic of Croatia on the participation of the Republic of Croatia in the European Union Rule of Law Mission in Kosovo, O.J. L 317, 27.11.2008, at 20 .

456. Council of the European Union, supra note 443, at 14.

457. Id. at $14-15$.

458. Id. at $14-18$. 
otherwise in conformity with the UN Charter. Respect for the rule of law and applicable human rights and/or international humanitarian law (in situations of armed conflict or occupation) is explicitly laid down as a duty in all EU rule of law missions. ${ }^{459}$ So far, only the beginning of operation EULEX Kosovo has raised some controversy due to the fact that the EU has not, unlike some of its Member States, recognized Kosovo as an independent state, (the EU operates in Kosovo under UNSC Resolution 1244). ${ }^{460}$

The EU Rule of Law Mission in Kosovo (EULEX Kosovo) is the largest civilian mission ever launched and therefore it likely serves as a model. Its central aim is to assist and support the Kosovo authorities in the rule of law and in particular, in the police, judiciary, and customs. It also explicitly provides that all the activities of the mission, "respect international standards concerning human rights and gender mainstreaming." "461 Other EU rule of law missions include EUJUST Themis (Georgia), ${ }^{462}$ which provided for EU assistance in the development of a horizontal governmental strategy for a new criminal justice, judicial, and anti-corruption reform, new legislation, and cooperation in the area of justice. Another example is the EU integrated rule of law mission for Iraq, EUJUST LEX Iraq, ${ }^{463}$ which addresses urgent needs in the Iraqi criminal justice system through training for senior and mid-level officials in senior management and criminal investigations. Outside rule of law missions, elements of the rule of law may form part of the mandate, e.g., of the EU security sector reform missions. Thus, EUPOL DR Congo, the EU police mission undertaken in the framework of the Congolese security sector and its interface with the Congolese system of justice contributes "to improving interaction between the police and the criminal justice system in the broader sense." ${ }^{464}$ EUSEC DR Congo, the EU mission that provides advice and assistance for security sector reform in the DR Congo ${ }^{465}$ makes explicit that "the aim of assisting the Congolese authorities in setting up a defence

459. Id. at $10-11$.

460. Council Joint Action 2008/124/CFSP, of 4 Mar. 2008 on the European Union Rule of Law Mission in Kosovo, EULEX KOSOVO, 2008 O.J. (L 42) 92, amended by Council Joint Action 2009/445/CFSP, of 9 June 2009 amending Joint Action 2008/124/CFSP on the European Union Rule of Law Mission in Kosovo, EULEX KOSOVO, 2009 O.J. (L 148) 33. 461. Id. at 93 .

462. Council Joint Action 2004/523/CFSP, of 28 June 2004 on the European Union Rule of Law Mission in Georgia, art. 2, 2004 O.J. (L 228) 21.

463. Council Joint Action 2009/475/CFSP, of 11 June 2009 on the European Union Integrated Rule of Law Mission for Iraq, art. 2, 2009 O.J. (L 156) 57.

464. Council Joint Action 2009/769/CFSP of 19 Oct. 2009, 2009 O.J. (L 274) 45; Council Joint Action 2007/405/CFSP of 12 June 2007, 2007 O.J. (L 151) 46, 47.

465. Council Joint Action 2009/709/CFSP of 15 Sept. 2009, art. 1(1), 2009 O.J. (L 246) 33, 34. 
apparatus capable of guaranteeing the security of the Congolese people," has to respect "democratic standards, human rights and the rule of law, as well as the principles of good governance and transparency." ${ }^{466}$ Some EU civilian crisis management operations specifically detail the rule of law aspects in their mission statements.

In the past, inter-institutional discrepancies relating to questions of powers and competences have arisen between the European Commission and the Council. The European Commission favors rule of law missions led by the Commission under non-CFSP instruments, ${ }^{467}$ whereas the Council of the European Union favors CFSP action led by the Council. These discrepancies have on occasion created difficulties in the EU decision-making process, and some have been arbitrated by the Court of Justice. ${ }^{468}$ In order to avoid these discrepancies, the Treaty of Lisbon has introduced new provisions aiming to reinforce the consistency and effectiveness of the EU external action as a whole by requiring mutual respect between CFSP and non-CFSP competences pursuant to Article 40 TEU. Furthermore, the Articles 18, 21(3), and 27 TEU Treaty of Lisbon confer on the new High Representative for the Common Foreign and Security Policy of the Union new powers within the Council (i.e. the chair of the Foreign Affairs Council) and within the European Commission (as vice-president of the Commission in charge of the coordination of the non-CFSP external action of the Union), in addition to those competences already attributed under the pre-Lisbon regime. The High Representative is assisted by the European External Action Service (EEAS) composed of officials transferred from the European Commission, the General Secretariat of the Council and the Diplomatic Services of the Member States (Council Decision 2010/427/EU adopted on July 26, 2010; OJ 2010, L. 201).

466. Id.

467. They were undertaken within the framework of the EU Assistance for Reconstruction, Development and Stabilisation (CARDS), Council Regulation 2666/2000, 2000 O.J. (L 306) 1 (EC) (in the context of judges and prosecutors to be sent to Bosnia-Herzegovina), as well as of the Human Rights Regulation 1889/2006, 2006 O.J. (L 386) 1 (EC), in the case of EU action complementing the local judicial system with an international rule of law component under CFSP within the framework of the first crisis management Exercise (CME 02), and of Regulation 1717/2006, 2006 O.J. (L 327) 1 (EC), establishing an Instrument for Stability.

468. See Case C-91/05, Comm'n of Eur. Cmtys. v. Council of the Eur. Union, 2008 E.C.R. I-3651 (regarding the legal base for the adoption of EU measures in relation to the non-proliferation of small arms and light weapons). 


\section{(b) The Rule of Law and EU Military Operations}

The EU has developed a solid legal framework for its military operations. This framework has been reinforced by the new provisions inserted into the TEU by the Treaty of Lisbon. The new TEU provisions set out, in quite some detail, the legal bases, procedures, and competences of the different actors pursuant to Title V, Chapter 2 TEU, (especially Section 2, i.e. Articles 42-46). As with civilian operations, the basic legal instrument governing each EU military operation is a Council decision adopted on the basis of Article 43 (Lisbon) TEU, in conjunction with Articles 28 and 31 TEU. As with its civilian missions, EU decisions on military operations set out the objectives, the mission mandate, the chain of command, provisions on the participation of other actors, and various other parameters. ${ }^{469}$ Of particular relevance are the EU planning documents leading to the launching of the EU military operation. The Operation Plan is the plan for the operation that includes the elaboration of the tasks, the means required, the command and control structure, and the way in which the Commander intends to conduct the operation. The Operation Plan also includes an explanation of when the use of force may be required, and sets out the rules of engagement $(\mathrm{ROE})^{470}$ which determine when, where, and how force is to be used. The rules of engagement are approved by the Council (by unanimity of all the Member States) usually at the same time the decision is made to launch the operation.

In addition to these provisions the European Union has concluded a number of international agreements relating inter alia to the participation of third States in EU military operations ${ }^{471}$ and the status of forces agreements. ${ }^{472}$ These agreements define the legal position of the operation and its military personnel. Such agreements have been concluded on the basis of Article 24

469. See, e.g., Council Joint Action 2008/851/CFSP, of 10 Nov. 2008 on a European Union Military Operation to Contribute to the Deterrence, Prevention, and Repression of Acts of Piracy and Armed Robbery off the Somali Coast, 2008 O.J. (L 301) 33 (subsequently corrected and amended).

470. The rules of engagement (ROE) may be described in short as instructions concerning the use of force. See International Institute of Humanitarian Law, Rules of Engagement Handbook (2009), available at $\mathrm{http} / / / \mathrm{www}$. iihl.org/iihl/Documents/rule\%20engagement $\% 20 \mathrm{definitive.pdf.}$

471. The EU has adopted a Model Framework Participation Agreement and a Model (ad hoc) Participation Agreement. See, e.g., Agreement Between the European Union and the Russian Federation on the Participation in the European Union Military Operation in the Republic of Chad and in the Central African Republic (EUFOR Tchad/RCA), 2008 O.J. (L 307) 16; other agreements include Croatia, O.J. L 307, 18.11.2008, at 33; Albania, O.J. L 307, 18.11.2008, at 19 etc.

472. See, e.g., Agreement Between the European Union and the Republic of Chad on the Status of the European Union-led forces in the Republic of Chad, 2008 O.J. (L 83) 40. 
pre-Lisbon EU Treaty and are now governed by Articles 37 of (Lisbon) TEU and 218 of the Treaty on the Functioning of the European Union. ${ }^{473}$

As we have seen, the EU military operations are "committed to upholding and developing International Law." ${ }^{474}$ This is reflected in the following elements: first, as with civilian missions, EU military operations can have different bases in international law. The most common bases have been UN Security Council Resolutions, ${ }^{475}$ consent by the host state government, or a peace agreement. In some cases, several of these bases are combined. Another basis in international law, is illustrated by Operation Atalanta, the counterpiracy operation off the coast of Somalia. This operation was based on the UN Convention on the Law of the Sea). So far, these international legal bases have not been controversial in any of the EU's military operations.

Secondly, the EU will normally conclude a Status of Forces Agreement (SOFA) (based on a model adopted by the Council) with the host state. This agreement will regulate the status and activities of an operation in the host state including provisions on identification, entry into the host state's territory, freedom of movement, the wearing of uniforms, the carrying of arms, the exercise of criminal jurisdiction by sending States, privileges and immunities of the operation and the forces, host state support and contracting, handling of deceased personnel, security of the forces and military police, communications, handling of claims, implementing arrangements, and the settling of disputes. ${ }^{476} \mathrm{In}$ addition, the Member States have concluded amongst themselves an agreement to regulate the status of their forces within each others' territory (EU SOFA, not yet entered into force at the time of print), ${ }^{477}$

473. Many of the EU military documents relating to EU military operations, including almost all of the legal instruments, are accessible to the public and are usually published in the Official Journal. Key sources are the CSDP pages on the Council's website as well as the public register of Council documents.

474. European Council, A Secure Europe in a Better World, at 9 (Dec. 12, 2003), available at http://www.consilium.europa.eu/uedocs/cmsUpload/78367.pdf.

475. The 2003 European Security Strategy indicates that: "The fundamental framework for international relations is the United Nations Charter. The United Nations Security Council has the primary responsibility for the maintenance of international peace and security." Id.

476. See Council of the European Union, Revised draft Model Agreement on the status of the European Union-led forces between the European Union and a Host State, Doc. 12616/07 (Sept. 6, 2007), available at http://register.consilium.europa.eu/pdf/en/07/st12/st12616.en07.pdf; Council of the European Union, Draft Model Agreement on the status of the European Union-led forces between the European Union and a Host State, Doc. 11894/07 (Sept. 5, 2007), available at http://register.consilium.europa.eu/ pdf/en/07/st11/st11894-co01.en07.pdf; Council of the European Union, Draft Model Agreement on the status of the European Union-led forces between the European Union and a Host State, Doc. 11894/07 (July 20, 2007), available at $\mathrm{http}: / /$ register.consilium.europa.eu/pdf/en/07/st11/st11894.en07.pdf.

477. See 2003 O.J. (C 321) 6 (EU); Aurel Sari, The European Union Status of Forces Agreement, 13 J. CONFLict \& SeC. LAW 353 (2008). 
and an agreement on any claims between them for damage to any property, injury, or death suffered by any staff in the context of an EU crisis management operation (not yet entered into force at the time of print). ${ }^{478}$

Thirdly, the arrangements for the participation of a third State in an EU military operation are laid down in a participation agreement with the EU. Such agreements may be concluded on an ad hoc basis for a given operation (on the basis of a standard agreement) or may take the form of framework agreements covering participation generally in EU operations. ${ }^{479}$

International humanitarian law or the law of armed conflict ${ }^{480}$ only applies to situations of armed conflict and occupation. Therefore, the EU and its Member States accept that if EU-led forces become a party to an armed conflict, ${ }^{481}$ international humanitarian law would fully apply to them. ${ }^{482}$ In the context of the EU, this was reflected in the Salamanca Presidency Declaration, which provided that " $[\mathrm{r}]$ espect for International Humanitarian Law is relevant in EU-led operations when the situation they are operating in constitutes an armed conflict to which the forces are party." ${ }^{\prime 43}$ This position corresponds with the position reflected in Article 2(2) of the 1994 Convention on the Safety of United Nations and Associated Personnel. ${ }^{484}$ However, given that only some EU military operations might involve the use of armed force by EU personnel as combatants, international humanitarian law is only likely to be applicable in a few EU operations. Therefore, the EU position is that international humanitarian law does not necessarily apply in all EU operations. ${ }^{485}$ So far EU-led forces have not become engaged in combat as a

478. 2004 O.J. (C 116) 1 (EC).

479. See, e.g., The Agreement Between the European Union and the Republic of Albania on the Participation of the Republic of Albania in the European Union Military Operation in the Republic of Chad and in the Central African Republic (Operation EUFOR Tchad/RCA), 2008 O.J. (L 219) 74.

480. These terms are used interchangeably in this contribution.

481. Although the contrary is often thought, in the EU Treaty "tasks of combat forces in crisis management, including peacemaking" cover peace enforcement and hence potentially high-intensity operations involving combat. NAERT, supra note 439, at 95-96, 197-206 (2010).

482. See generally id. at 463-540; Marten Zwanenburg, Toward a More Mature ESDP: Responsibility for Violations of International Humanitarian Law by EU Crisis Management Operations, in The European Union and International Crisis Management, supra note 439, at 395, 395-416. 483. The outcome of the international humanitarian law European seminar of 22-24 April 2002 in Salamanca, Doc. DIH/Rev.01.Corr1.

484. Convention of the Safety of United Nations and Associated Personnel, 34 I.L.M. 482, 487 (1995). Article 2(2) stipulates that "This Convention shall not apply to a United Nations operation authorized by the Security Council as an enforcement action under Chapter VII of the Charter of the United Nations in which any of the personnel are engaged as combatants against organized armed forces and to which the law of international armed conflict applies."

485. See also Frederik Naert, Challenges in Applying International Humanitarian Law in Crisis 
party to an armed conflict in any of the EU's military operations. Though international humanitarian law was not applied, it could have been utilized if the situation had escalated in certain operations, especially Artemis ${ }^{486}$ and EUFOR Chad/RCA. ${ }^{487}$ In Artemis, a few isolated incidents were reported but these did not seem sufficient to have crossed the threshold into armed conflict. ${ }^{48}$ Although EUFOR Chad/RCA was conducted in a challenging environment in which several armed conflicts were ongoing, ${ }^{489}$ the EU stressed repeatedly that "in observance of its mandate, EUFOR Chad/RCA would act with full independence, impartiality and neutrality." ${ }^{490}$ Although a number of incidents occurred, it seems that this approach was well understood and the operation did not get involved in the various conflicts. ${ }^{491}$

Management Operations Conducted by the EU, in L'Union Europeenne et Le Droit InTERNATIONAL Humanitaire 139, 142 (Anne-Sophie Millet-Devalle ed., 2010).

486. Council Joint Action 2003/423/CFSP, of 5 June 2003 on the European Union Military Operation in the Democratic Republic of Congo, 2003 O.J. (L 143) 50.

487. Council Joint Action 2009/795/CFSP, repealing Joint Action 2007/677/CFSP on the European Union Military Operation in the Republic of Chad and in the Central African Republic, 2009 O.J. (L 283) 61.

488. For example, on 16 June EU forces under attack returned fire and killed two attackers. See Operation Artemis: Mission Improbable?, EuR. Sec. Rev. (Int'1 Sec. Info. Serv., Brussels, Belg.), July 2003, at 6 n.3.

489. In particular, there was an internal armed conflict in Chad as well as in Sudan, and both countries had accused each other of supporting rebels fighting the respective governments. See, e.g., The Secretary-General, Report of the Secretary-General on the United Nations Mission in the Central African Republic and Chad, 9 7-14, delivered to the Security Council, U.N. Doc. S/2008/215 (Apr. 1, 2008); The Secretary-General, Report of the Secretary-General on the United Nations Mission in the Central African Republic and Chad, 9 - 10-15, delivered to the Security Council, U.N. Doc. S/2008/444 (July 8, 2008). In fact, it would seem that on two occasions, EUFOR personnel/assets were attacked by Sudanese armed forces. See The Secretary-General, Report of the Secretary-General on the United Nations Mission in the Central African Republic and Chad, $\uparrow 35$, UN Doc. S/2008/215 (Apr. 1, 2008); The Secretary-General, Report of the Secretary General on the United Nations Mission in the Central African Republic and Chad, - 4, S/2008/760 (Dec. 4, 2008). These appear to have been isolated incidents that did not lead to any escalation. On the former incident, see also Press Release, EUFOR TCHAD/RCA, EUFOR Suffers Its First Fatality (Mar. 10, 2008); Press Release, EUFOR TCHAD/RCA, Remains Found in Sudan Believed to that of EUFOR Peacekeeper (Mar. 5, 2010); Press Release, EUFOR TCHAD/RCA, Lieutenant General Nash Appeal for Information on Missing EUFOR Peacekeeper (Mar. 4, 2010); Press Release, EUFOR TCHAD/RCA, OHQ Mont Valérien (Mar. 3, 2010), http://www.consilium.europa.eu/showPage.aspx?id $=\&$ lang $=$ en.

490. See, e.g., Council of the European Union, Conclusions of the External Relations Council, May 26-27, 2008, EU Council Doc. 9868/08, 33 ("In observance of its mandate EUFOR Chad/RCA will act in an impartial, neutral and independent manner."); Council of the European Union, Conclusions of the External Relations Council, Oct. 15-16, 2007 (EU Council Doc. 13720/07), 10 ("The operation will be conducted with full independence, impartiality and neutrality.").

491. For a summary account of two incidents, see Press Release, EUFOR TCHAD/RCA, EUFOR Troops Challenge and Disperse Ambushers (Aug. 19, 2008); Press Release, EUFOR TCHAD/RCA, EUFOR Action Under Fire Protect IDP's Refugees (June 14, 2008), available at http://www.consilium 
When international humanitarian law does not apply, the EU primarily looks towards human rights law as the appropriate standard for the conduct of EU operations. ${ }^{492}$ Admittedly, the applicability of human rights as a matter of law remains controversial in some respects. These controversies include the extraterritorial application of the European Convention on Human Rights, the question of derogation in times of emergencies and its applicability to peace operations, the relationship between human rights and international humanitarian law ${ }^{493}$ and the impact of UN Security Council mandates on human rights. ${ }^{494}$ However, as a matter of policy and practice, human rights provide significant guidance in EU operations. Furthermore, pursuant to Article 6 of the (Lisbon) TEU, the EU "recognises the rights, freedoms and principles set out in the Charter of Fundamental Rights of the European Union of 7 December 2000, as adapted at Strasbourg, on 12 December 2007, which shall have the same legal value as the Treaties." 495 In addition, (as was the case before the Lisbon Treaty), the EU is bound by human rights as general principles of EU law. Since the Lisbon Treaty took effect, it is now also provided that the EU must accede to the European Convention on Human Rights pursuant to Article 6(2) (Lisbon) TEU. ${ }^{496}$ Therefore, EU operational planning and rules of engagement fully respect internationally recognized standards of the rule of law and human rights law. ${ }^{497}$ This has been explicitly

.europa.eu/showPage. aspx?id=1368\&lang=en.

492. See generally NAERT, supra note 439, at 541-658; F. Naert, Accountability for Violations of Human Rights Law by EU Forces, in The European Union and International Crisis Management: Legal and Policy AsPects, supra note 439, at 375, 375-93.

493. For a partial EU perspective, see European Union Guidelines on Promoting Compliance with International Humanitarian Law (IHL), 2005 O.J. (C 327) 4, 5; Updated European Union Guidelines on Promoting Compliance with International Law (IHL), 2009 O.J. (C 303) 12, 13.

494. By virtue of Article 103 of the UN Charter, obligations under the UN Charter prevail over other international agreements. States often invoke this as a basis for partially limiting or setting aside certain human rights in peace operations. For a leading judgment, see R (on the application of Al-Jedda) v. Sec'y of State for Defence, (2007) A.C. 58 (H.L.), available at http://www.publications.parliament.uk/pa/ ld200708/ldjudgmt/jd071212/jedda-. However, this is not uncontested and the European Court of Justice has shown far less deference to the UN Charter in some of its judgments on counter-terrorism measures. See, e.g., Case C-402/05 P, Kadi v. Council of the Eur. Union, (Sept. 3, 2008). The European Court of Human Rights has essentially shied away from ruling on this question so far. See, e.g., Behrami and Behrami v. France (Application No. 71412/01) and Saramati v. France, Germany and Norway (Application No. 78166/01), May 31, 2007.

495. 2008 O.J. (C 115) 13, 19.

496. Id.

497. See also European Community, Mainstreaming Human Rights and Gender into European Defense and Security Policy, (2008), available at http://www.consilium.europa.eu/ueDocs/cms_Data/ docs $/$ hr/news144.pdf. 
reflected in the EU decisions establishing some of the more recent EU military operations such as the EU EUNAVFOR Somalia/Atalanta operation. ${ }^{498}$

In particular, references to respect for human rights as an element of the rule of law are incorporated in the EU Atalanta military operation off the Somali coast and in transfer agreements dealing with the conditions of transfer of suspected pirates. Thus, Article 12(2) of the Council Joint Action 2008/851/CFSP (Atalanta) of 10 November 2008 provides that "no persons" involved in acts of piracy who are arrested or detained in the course of the EU operation:

[M] ay be transferred to a third state unless the conditions for the transfer . . . (are) consistent with ... international law, notably ... human rights, in order to guarantee that no one shall be subject to the death penalty, to torture or to any cruel, inhuman or degrading treatment. ${ }^{499}$

Moreover, the transfer agreements contain provisions ensuring that the persons transferred are treated in accordance with human rights and with the requirements of a fair trial. ${ }^{500}$

The promotion of the rule of law in EU military operations does not usually constitute a priority. Instead, this tends to be a task for other actors that are present in theatre (e.g., an EU civilian CSDP operation, other EU measures ${ }^{501}$ or a mission by the UN or OSCE which intervene in parallel with the military operation). However, in some cases, military CSDP operations may be specifically mandated to undertake rule of law (related) tasks. Thus, the EU guidelines on international humanitarian law provide, inter alia, that:

(15(b)) Whenever relevant ... Commanders of EU Military Operations ... should include an assessment of the IHL situation in their reports about a given State or conflict. Special attention should be given to information that indicates that serious violations of IHL may have been committed. Where feasible, such reports should also include an analysis and suggestions of possible measures to be taken by the EU ... (16(f)) Crisis-management operations: The importance of preventing and suppressing violations of IHL by third parties should be considered, where appropriate, in the drafting of mandates of EU crisis-management operations. In

498. See generally NAERT, supra note 439, at 179-91.

499. O.J. L 303, 12.11.2008, p. 33.

500. Exchange of letters between the EU and the government of Kenya, 2009 O.J. (L 79) 49; Exchange of letters between the EU and the Republic of Seychelles, 2009 O.J. (L 315) 37.

501. In the context of Operation Atalanta, the EU is providing, under the Stability Instrument, aid on capacity-building for the Kenyan judicial system so as to reinforce its ability to prosecute suspected pirates while respecting human rights. 
appropriate cases, this may include collecting information which may be of use for the ICC or in other investigations of war crimes. ${ }^{502}$

In practice, EU military CSDP operations always take into account rule of law considerations. This is specifically provided in the reporting mechanisms applicable to operations, such as human rights and gender advisers.

\section{(viii) Overall evaluation}

At present, ${ }^{503}$ the EU possesses a comprehensive framework for the promotion of democracy, human rights, the rule of law, and "good governance." This framework covers the whole world, and consequently, the EU has become a major "civilian power." 504 The various EU policies consist of remarkably similar instruments, but differ mainly with regard to the steering mechanisms which are established for the implementation of requirements imposed by the respect of the rule of law, democracy, and human rights. These mechanisms are mainly of three types. First, there are "political dialogues" based on persuasion and learning strategies. Second, there are clauses on "political conditionality" which are based on cost-benefit calculations and which create incentive structures. And third, there are programs establishing "capacity-building" for the institutionalization of democracy, human rights, and the rule of law. These three types of instruments are used in all geographical locations.

The EU follows the same approach everywhere: the establishment of legal instruments as the starting-point and support for the enforcement of those instruments by the local authorities as the end result. This approach is consistent with the EU Security Strategy: in order to induce compliance with its policies, the EU stresses a preference for "soft security" and "soft power" in foreign policy. For that purpose, it uses positive incentives, capacitybuilding, persuasion, and learning. ${ }^{505}$ Of course, the EU is sometimes not fully

502. European Union Guidelines on promoting compliance with international humanitarian law (IHL), 2005 O.J. (C 327) 4, 5-6.

503. Until 1999, the EU had targeted the promotion of the rule of law democracy and human rights. Its policy mainly focused on economic cooperation under which the Member States continue to have their own policies. Thus, the EU assumed a rather weak role acting as an additional donor rather than a coordinator of European development policies.

504. Tanja A. Börzel \& Thomas Risse, Venus Approaching Mars? The EU as an Emerging Civilian World Power, 34 Archive of European Integration (AEI) (PDF format) (Berlin Working Paper on European Integration, 2009).

505. Id. 
consistent when dealing with infringements of the rule of law and human rights. It is tough on Myanmar, but rather soft on China. In many cases, it does not use the instruments available in the various partnership agreements, or uses them only reluctantly. Indeed, it has been pointed out that "inconsistent use" of political conditionality mitigates the "transformative power of the EU" and damages the EU "international credibility as a normative power." Nevertheless, a quantitative study of the use of EU "carrots and sticks" in its rule of law and human rights policies has not revealed that the EU acts with a particular bias one way or another. ${ }^{507}$ The EU policies are implemented in a differentiated way, but this difference in treatment is not the result of a systematic pre-eminence of economic and security interests over considerations for the rule of law, democracy, and human rights. The evolution of EU policies on the rule of law has followed a pragmatic approach - that is, "learning by doing." evolution of the policy of conditionality, which was first developed in relations with the ACP countries as part of the 1990 Lomé IV agreement. This was then quickly introduced in the form of positive conditionality (closeness to the EU) and a weak form of negative conditionality (economic support provided if there is compliance with the rule of law) in relations with the Central Eastern European and Northern African countries during the early 1990s. ${ }^{509}$

In short, the EU emphasis is on "value export"- the promotion of the rule of law, democracy, and social and economic rights. This EU external action distinguishes itself from the U.S. version of "freedom, democracy and capitalism." This distinction has brought practical consequences. For example, in Latin America where the EU and the United States seem to compete, the EU tries to promote its own model of regional integration, i.e., by including strong supranational institutions going beyond mere free trade areas, which is the preferred American option.

Above all, the EU's external policy for the promotion of the core EU values of the rule of law, democracy, and human rights is firmly integrated in the overall framework of crisis management, as explicitly required in the

506. Tanja A. Börzel, The Transformative Power of Europe Reloaded: The Limits of External Europeanization 25 (Freie Universität Berlin, KFG Working Paper Series No. 11, 2010), available at http://www.daad.de/imperia/md/content/de/zentren/boerzel.pdf.

507. Hadewych Hazelet, Carrots or Sticks? EU and US Sanctions in Reaction to Human Rights Violations (Sept. 17, 2001) (unpublished Ph.D. dissertation, European University Institute).

508. Judith G. Kelly, Ethnic Politics in Europe: The Power of Norms and Incentives (Princeton Univ. Press 2004).

509. The so-called Europe Agreements. 
European Security Strategy. The European strategic vision in crisis management purports to create democratic societies as a means to achieve peace, stability, and wealth. For that purpose, the EU should act as a "soft power," or a "small power" for some analysts, ${ }^{510}$ and have recourse to "effective multilateralism." Behaving as a "soft power" has not prevented the Union from becoming, within a relatively short period of time (ten years or so), a major player in post-conflict peace-building and reconstruction efforts, including robust peacekeeping. With regard to the peace-keeping, EU Member States provide a large number of troops in the various peace-keeping operations, be it under UN auspices, under NATO, or under EU autonomous operations. The EU is now a major contributor to the $\mathrm{UN}$ with regard to peace-keeping, but at the same time EU military missions also operate within the EU's larger political stabilization and peace-building objectives for the promotion of democracy, human rights, and the rule of law. ${ }^{511}$ Indeed, while the immediate goal is to provide security and stability, all EU missions have been linked to the long-term goal of rule of law, state-building, and democracy promotion that require civilian rather than military measures.

A strong emphasis is put on security sector reform as an important condition for successful state-building and democratic transformation. A major focus is (democratic) control of those actors who command executive and coercive power. This is why some EU missions have made training and monitoring police forces a major priority. Most military operations have been complemented or followed up by so-called civilian police (EUPOL) missions for the building and reforming of police institutions in accordance with rule of law requirements. For a supranational entity, this EU action is quite unique and comprehensive, as it enables the EU to provide a whole package of political, economic, social, cultural, and military measures in crisis prevention, crisis management, and post-conflict situations even though coordination between the various EU agencies and the EU delegations on the ground can be challenging.

Having recourse to "effective multilateralism" provides that all EU missions have been either requested or at least endorsed by the UN. ${ }^{512}$ The EU

510. Asle Toje, The European Union as a Small Power 183 et seq. (Palgrave MacMillan, New York 2010).

511. See Börzel \& Risse, supra note 504, at 36.

512. The EU explicitly recognizes the UN Security Council as primarily responsible for the maintenance of international peace and security. See Council of the European Union, Joint Statement on UN-EU Cooperation in Crisis Management (June 7, 2007); European Council, EU-UN Cooperation in Military Crisis Management Operations: Elements of Implementation of the EU-UN Joint Declaration, Annex II, ESDP Presidency Report, European Council (June 17-18, 2004); Council of the European Union, 
considers that it acts in accordance with international law when its operations take place without a UN mandate but with the consent of the host state in practice and the UN has often later endorsed these EU missions in one way or another. ${ }^{513}$ The EU has become a reliable "burden-sharing" partner, particularly in areas such as rapid reaction to humanitarian crisis and sustainable post-conflict management. The EU has also cooperated with other international and regional organizations, such as the OSCE in both the Western Balkans (FYROM and Bosnia-Herzegovina) and on Russia's borders (Georgia, Ukraine, and Moldova), the African Union (Sudan), and the ASEAN (Aceh/Indonesia). The cooperation with NATO is of course fundamental: the EU and NATO have concluded the "Berlin Plus" Agreement. ${ }^{514}$ That agreement provides a framework for the consultation and cooperation between NATO and the EU and has also prevented dissensions between the United States and its major European allies. Yet EU/NATO cooperation has not proven to be fully satisfactory, in particular when the EU acts autonomously and NATO also operates in the same place, such as in Afghanistan. Coordination, in these instances, has been weak.

In short, the EU's role in conflict resolution and peace-building has transformed it into a major "civilian power," which subordinates the purely military and security interests to the civilian objectives relating to the reform of the capacity-building and positive conditionality. While the EU does not prevent the use of military force in its military operations, the latter is integrated in the overall framework of an EU concept of crisis management

Joint Declaration on UN-EU Co-operation in Crisis Management, Doc. 12730/03 (Sept. 19, 2003), available at http://www.consilium.europa.eu/showPage.aspx?id=\&lang=en. The two organisations have established a joint consultative mechanism (Steering Committee) to examine ways of enhancing mutual cooperation in planning, training, communication and the exchange of best practice. The two organizations agreed to develop mutually reinforcing approaches to conflict prevention and to ensure that the EU's evolving military and civilian capacities would provide real added value for $\mathrm{UN}$ crisis management. EUPOL Kinshasa served as a test operation demonstrating that the EU can contribute effectively to a UN peacekeeping operation.

513. Thierry Tardy, EU-UN Cooperation in Peacekeeping: A Promising Relationship in a Constrained Environment, in The European Union and the United Nations 49, 51 (M. Ortega ed., 2005) (stating that the capacity of the EU for autonomous operations under the Common Security and Defence Policy (CSDP) has not distracted European contributions from UN peace-keeping because while some EU Member States may be reluctant to place their troops under UN command, they contribute $39 \%$ of the UN peace-keeping budget (compared to $22 \%$ of the United States) and $37.75 \%$ of the regular budget (compared to $27 \%$ of the United States)).

514. European Security and Defence Assembly/Assembly of the Western European Union, The EUNATO Berlin Plus Agreements, Assembly Fact Sheet No. 14 (Nov. 2009), http://www.europarl .europa.eu/meetdocs/2004_2009/documents/dv/berlinplus_/berlinplus_en.pdf (containing a series of arrangements for EU access to NATO assets and capabilities). 
that combines the use of financial, civilian, and military instruments in order to transform and adapt countries to the requirements of the rule of law. The question arises as to how the EU vision compares with that of the United States.

\section{The Rule of Law in the External Action of the United States}

American scholars have suggested that the strength of the adherence of a country to the rule of law in international affairs is essentially linked to the extent to which international law can be enforced through national mechanisms. ${ }^{515}$ Therefore, the question arises as to how international law is enforced through American mechanisms.

\section{(i) The United States and International Law}

It is worth mentioning that the United States Supreme Court has held that "[w]hen the United States declared their independence, they were bound to receive the law of nations, in its modern state of purity and refinement." 516 Therefore, the United States has systematically accepted that international legal commitments are binding upon it both internationally and domestically in accordance with the following principles.

The Supreme Court has also held that customary international law binds the United States and is "part of our law," meaning that it is integrated into the law of the United States through the common law when "there is no treaty, and no controlling executive or legislative act or judicial decision" in conflict. ${ }^{517}$ In 1900, the Supreme Court held that customary international law "is . . our law" only when there is not a controlling executive or legislative act in force. ${ }^{518}$ Thus, while customary international law may be part of the law of the land, it has limited applicability when it is in conflict with a domestic law that has been adopted later in time. As a result, the United States can exempt itself from the requirements of customary international law by adopting a statute to the contrary pursuant to "last in time" rule ${ }^{519}$ provided. Of course, it is required that the statute does not violate any rule of

515. John F. Murphy, The United States and the Rule of Law in International Affairs 74 (Cambridge Univ. Press 2004).

516. Ware v. Hylton, 3 U.S. 199, 281 (1796).

517. The Paquete Habana, 175 U.S. 677, 700 (1900).

518. $I d$.

519. Whitney v. Robinson, 124 U.S. 190, 194 (1888). 
international customary law that has acquired the status of $j u s$ cogens. ${ }^{520}$ The Supreme Court has so far never declared a U.S. statute non-applicable on the ground that it violated customary international law. In any case, customary international law can potentially affect how domestic law is interpreted.

"The United States assumes international obligations most frequently when it concludes agreements with other states or international organizations that are intended to be legally binding. Once concluded by the United States, such agreements are legally binding and can take the form of an international treaty or an executive agreement." ${ }^{, 521}$ A treaty is an agreement negotiated and signed by the executive that enters into force if it is approved by a two-thirds majority of the Senate and is subsequently ratified by the President. It should be noted that the Senate may also propose amendments to the text of the treaty itself and that, in such case, the other contracting parties to the agreement would have to consent to the changes in order for them to take effect. However, "the great majority of international agreements concluded by the United States are not treaties but executive agreements that are entered into by the executive without being submitted to the Senate for its advice and consent, although Congress generally requires notification upon the entry into force of such an agreement." 522 Although the Constitution of the United States does not mention the category of executive agreements, they have nonetheless been considered to be valid international commitments by the Supreme Court and as a matter of historical practice. ${ }^{523}$ There are three types of executive agreements: first, the so-called "congressional-executive agreements," in which Congress has authorized the conclusion of an international agreement by the executive before its conclusion or after its conclusion with retroactive effects; second, the so-called "executive agreements made pursuant to an early treaty," in which the conclusion of an executive agreement has been authorized by a ratified treaty; and third, the so-called "sole executive agreements" in which an agreement is made pursuant to the constitutional authority of the President without any authorization either by the Congress or by a prior treaty. ${ }^{524}$

520. See Buell v. Mitchell, 274 F.3d 337 (6th Cir. 2001) (stating that for a norm to constitute jus cogens state practice must be extensive and virtually uniform).

521. Michael J. Garcia, Cong. Research Serv., Rl32528, International Law and Agreements: Their EFFect Upon U.S. LAW 1 (2010).

522. Id. at 3 .

523. Am. Ins. Ass'n v. Garamendi, 539 U.S. 396, 415 (2003).

524. See GARCIA, supra note 521, at 2-4. 
Pursuant to the Supremacy Clause in Article 6 of the Constitution, "all treaties made or which shall be made, under the authority of the United States, shall be the supreme law of the land and the judges in every state shall be bound thereby, anything in the Constitution or laws of any state to the contrary notwithstanding." ${ }^{525}$ In general, the effects of international agreements upon the domestic law of the United States depend upon the nature of the treaty or agreement, namely, whether the agreement is self-executing (i.e. which is able to operate automatically within the United States without the need for any municipal legislation $^{526}$ ), or not self-executing (i.e. when it requires legislation before it can be applied in the United States and bind American courts ${ }^{527}$ ), and whether it was made pursuant to a treaty or an executive agreement. ${ }^{528}$ Until implementing legislation is enacted, existing domestic law relating to the issues covered by an international agreement that is not self-executing remains in force. However, when a treaty is ratified or an executive agreement is entered into, the United States assumes obligations under international law and may be unable to apply those obligations unless implementing legislation is enacted.

Sometimes, a treaty or executive agreement may conflict with a state law, a federal law, or the Constitution. For domestic purposes, a ratified, selfexecuting treaty is part of the law of the land having a status equal to federal law, ${ }^{529}$ and superior to state law, ${ }^{530}$ but inferior to the Constitution. ${ }^{531}$ A selfexecuting executive agreement is likely to be superior to state law, ${ }^{532}$ but sole executive agreements may be inferior to conflicting federal law in certain circumstances, ${ }^{533}$ and all executive agreements are inferior to the Constitution.

As a rule, courts of the United States interpret statutes in such a way as to comply with the international obligations contracted by the United States, a principle known as the "Rule of Interpretation." Since the role of the American Court is to determine the intent of the legislature when the court interprets a statute, the recognized general public policy is to comply with international legal obligations and interpret statutes in such a way as to comply with international law. When statutes directly refer to international

525. U.S. CONST. art. VI.

526. Medellin v. Texas, 552 U.S. 491, 504 (2008)

527. Id. at 504-05.

528. GARCIA, supra note 521.

529. Whitney, 124 U.S. at 194.

530. Ware, 3 U.S. 199 at 237.

531. Reid, 354 U.S. 1.

532. Belmont, 301 U.S. 324.

533. Guy W. Capps, Inc., 204 F.2d 655. 
law, thereby incorporating its terms, international law is "incorporated by reference" into American law. If a U.S. statute refers to specific treaty provisions, the specific terms are thereby given the same force as the statute.

The record of U.S. compliance with international law is controversial. ${ }^{534}$ In some cases, the United States has taken the lead in multilateral efforts to create legal rules and institutions and has offered considerable (financial) support. In other cases, the United States has found that multilateral cooperation and acceptance of some form of international supervision are the best available options for "a superpower in a uni/multipolar world." For example, in the field of environmental law, notwithstanding its high-profile withdrawal from the Kyoto Protocol, American compliance with international commitments has been considered good. ${ }^{535}$ However, there have also been instances in which the U.S. attitude towards international law has been less favorable (e.g., the refusal to sign or ratify the Rome Statute of the International Criminal Court, the United Nations Convention on the Law of the Sea, or the Ottawa Convention on Landmines). Although the United States does not violate international law by refusing to accept these treaties, it is difficult to maintain that this position actively contributes to a strengthening of the international rule of law. This also applies to the U.S. reluctance to accept third party settlements in international disputes, or the possibility for its citizens to submit petitions to international supervisory bodies in the area of human rights. ${ }^{536}$ In yet other instances, the United States has simply violated international legal obligations, in the sphere of international peace and security, human rights and humanitarian law, (Guantánamo). and UN membership (UN dues). ${ }^{537}$

In particular, the issue of the UN dues withheld by the United States under Article 17 of the UN Charter has been severely criticized: "a sharper deviation from the rule of law paradigm is hard to imagine. ${ }^{, 538} \mathrm{Criticisms} \mathrm{have}$ also been made concerning the United States policy on cooperation with the

534. See Martha Minow, The Controversial Status of International and Comparative Law in the United States, 52 HARV. INT'L L.J. 1 (2010). For a criticism on the question of sovereign immunity in U.S. courts see D. Doernberg, Sovereign Immunity on the Rule of Law 71 et seq. 200 (Carolina Academic Press 2005).

535. Jutta Brunnee, The United States and International Environmental Law: Living with an Elephant, 15 EuR. J. INT'L L. 617 (2004).

536. Murphy, supra note 515.

537. Id. at 350. See Institute for Energy and Environmental Research and Lawyers Committee on Nuclear Policy, Rule of Power or Rule of Law? 29-41 (N. Deller, A. Makhijani \& Y. Borroughs eds., 2002).

538. Id. at 133 . 
rest of the international community on topics such as arms control, disarmament, non-proliferation, and safeguards (but this is changing with the Obama Administration).

Many of these criticisms are mainly based on a perceived negative effect that the former Bush administration had on cooperation in these areas. The difficulty that the United States has with accepting the rule of law in these areas had been "compounded with the coming into office of the George W. Bush administration because of its considerable distrust of any external constraints on its behaviour, especially the constraints imposed by international norms and institutions." 539 Particularly disturbing, is the aftermath of the Nicaraguan case with regard to the role of the International Court of Justice, which has led the United States to refuse to accept the compulsory jurisdiction of the Court for the foreseeable future. In the case of the International Criminal Court, the United States has combined several strategies to prevent the Court from prosecuting U.S. nationals (through the world order treaty, through bilateral treaties, and through unilateral measures).

What is the reason for such a controversial record? Part of the explanation may be found in the U.S. National Security Strategy ("NSS").

\section{(ii) The Rule of Law as a strategy in U.S. external action}

As with the EU's Security Strategy (ESS), U.S. external action on the rule of law is guided by its formalized National Security Strategy (NSS), a requirement of Congress for any U.S. President since $1986 .{ }^{540}$ The formalization of the NSS by the Obama administration took place in May 2010. The new President had indicated in some of his Presidential speeches, and through the speeches of his Secretary of State, H. Clinton (e.g., her speech at the Council on Foreign Relations in 2009), that his strategy would continue to be assertive abroad but with a change of emphasis. The new strategic goals are to reverse the spread of nuclear weapons and build a world free from the threat of their use and to isolate and defeat terrorists and counter violent extremists "while reaching out to Muslims around the world." " The Obama Strategy no longer refers to the "global war on terror" (a term commonly

539. Id. at 221.

540. See Goldwater-Nichols Department of Defense Reorganization Act of 1986, Pub. L. No. 99-433, 100 Stat. 992 (1986).

541. Hillary Clinton, U.S. Sec'y of State, U.S. Dep't of State, Foreign Policy Address at the Council on Foreign Relations (July 15, 2009), available at http://www.state.gov/secretary/rm/2009a/july/ 126071.htm. 
employed by the Bush administration) but states that the United States will continue to fight a war "against a far reaching network of hatred," while, at the same time, restoring "American values," banning torture, and safeguarding the legal rights of the terrorist held in detention and American "exceptionalism." 542 The new Strategy also commits the Obama administration to the encouragement and facilitation of the efforts of all parties to pursue and achieve a comprehensive peace in the Middle East as well as to seek global economic recovery and growth "by strengthening our own economy." 543 Indeed, it identifies the future security with America's economic recovery, putting emphasis on education, energy, science, and on the American ability to reinvent its rusting economic infrastructure. The new Strategy also seeks to advance a robust development agenda, to expand trade that is free and fair, to boost "investment that creates decent jobs," "544 to combat climate change, increase energy security and lay the foundation for a prosperous clean-energy future, and last but not least, to use the requirements of the rule of law to support and encourage democratic governments that "protect the rights and deliver results for their people." "[W]e intend to stand up for human rights everywhere." ${ }^{545}$ The new Administration brings back multilateralism to the center of its strategy (which had been relegated to the periphery in the NSS of the Bush Administration).

In contrast to the Bush Strategy, which asserted the U.S. hegemony ("the United States will never allow the rise of a rival super power if necessary by undertaking pre-emptory strikes"), the Obama NSS reverts to more traditional U.S. diplomacy. An essential part of the Obama strategy is its call for a "renewal of American leadership" by working with other partners, by recognizing the existence of a "multi-partner world" instead of "a multi-polar world" 546 with peer competitors, in which "America[] lea[ds] to solve problems in concert with others" ${ }^{547}$ because "no nation can meet the world's challenges alone." 548 Therefore "unity of effort" is paramount. The approach is that of a "tough and smart power" that brings all relevant domestic actors

542. President Obama Speech on Libya, Mar. 2011, White House, National Security Strategy of the United States of America 4 (2010), available at http://www.whitehouse.gov/sites/default/files/rss_viewer/ national_security_strategy.pdf. Former President Bush has admitted that he personally approved waterboarding as a policy of government. See G.W. Bush, Decision Points (Crown 2010).

543. Clinton, supra note 541.

544. $I d$.

545. $I d$.

546. $I d$.

547. $I d$.

548. Id. 
to the table and the playing field, and bases its external action upon several pillars. The first is the creation of strong mechanisms of cooperation "with our historic allies, with emerging powers, and with multilateral institutions, and to pursue that cooperation in . . . a pragmatic and principled way." ${ }^{549}$ The second is focused on developing leadership with diplomacy, "even in the cases of adversaries or nations with whom we disagree.... [D]oing so advances our interests and puts us in a better position to lead with our other partners[] [for] [w]e cannot be afraid or unwilling to engage." ${ }^{550}$ The third is upgrading and integration of development as a core pillar of American power. "[W]e advance our security, our prosperity, and our values by improving the material conditions of people's lives around the world. These efforts also lay the groundwork for greater global cooperation, by building the capacity of new partners and tackling shared problems from the ground up." ${ }^{551}$ The fourth strategy involves ensuring that "our civilian and military efforts operate in a coordinated and complementary fashion where we are engaged in conflict. This is the core of our strategy in Afghanistan and Iraq, where we are integrating our efforts with international partners." ${ }^{552}$ The final pillar is the reinforcement of the traditional sources "of our influences, including economic strength and the power of our example." 553

The application of these principles has had an evident and practical effect in Presidential demarches as it de-links terrorism from Islam and reduces the role of nuclear weapons in American defense, (e.g., the new Nuclear Posture Review (NPR)). This decreased role for nuclear weapons in American defense reduces the importance of nuclear weapons in the NSS and thus promotes the non-proliferation of weapons of mass destruction with the goal of achieving a nuclear-free world. This goal, asserts the policy of the defense of human rights throughout the world including in countries such as China.

What is not yet clear is how the United States will behave if diplomacy cannot prevent Iran from developing nuclear weapons, or cannot encourage developing states either to pursue clean energy policies or to recognize the right of oppressed peoples to achieve greater freedom. This leads one to question which parts of the Bush NSS, as recast in 2006, remain in force. One would venture to say that the basic principles remain the same: the promotion 
of "freedom, justice and human dignity," 554 the encouragement of democracy through "confronting the challenges of our time by leading a growing community of democracies," $" 555$ and the establishment of states abiding by the rule of law or "well governed states." The term "rule of law" is mentioned nine times in the $2002 \mathrm{NSS}$ and sixteen times in the $2006 \mathrm{NSS}^{556}$ ). In particular, the Preface to the 2009 edition of the Rule of Law Handbook published by the Centre for Law and Military Operations, incorporates the fundamental principle that "America must stand firmly for the non-negotiable demands of absolute power of the state; free speech, freedom of worship, equal justice, respect for women, religious and ethnic tolerance, and respect for private property." 557 Indeed, President Obama has remarked that "I believe that our nation is stronger and more secure when we deploy the full measure of both our power and the power of values, including the rule of law. ${ }^{, 58} \mathrm{We}$ know that the interpretation of those values by President Obama has changed in comparison with that of the Bush Administration. This is demonstrated by the attitude of President Obama to the situation in Guantánamo, as well as the question of the military tribunals and the redefinition of the prohibition of torture in the armed forces. But what about the means? The Bush doctrine of "pre-emption"- armed intervention-does not stand, but President Obama has not explicitly ruled out striking first: "the United States must reserve the right to act unilaterally if necessary to defend our nation and our interests, yet we will also seek to adhere to standards that govern the use of force. ${ }^{" 559}$ Will the Bush principles of "transformational" diplomacy apply in the same way during the Obama Administration? How do these traits of the American strategy compare with those of the European Union?

(iii) A comparison between the EU and U.S. strategies on the rule of law

In theory, the American NSS and the EU ESS do not greatly differ in their principles, particularly in their comprehension of the rule of law. ${ }^{560}$

554. White House, supra note 542.

555. Id.

556. See U.S. Dep't of Army, Rule of Law Handbook I (2008), available at http://www.au.af .mil/au/awc/awcgate/law/rule_of_law_hdbk.pdf.

557. Id. (quoting White House, National Security Strategy of the United States of America 3 (2002)).

558. Barack Obama, President, Remarks at CIA Headquarters (Apr. 20, 2009), available at https://www.cia.gov/news-information/speeches-testimony/president-obama-at-cia.html.

559. White House, National Security Strategy of the United States of America 22 (2010).

560. U.S. Army Peacekeeping and Stability Operations Inst., Rule of Law Conference REPORT JULY 6-9 2004, at 1 (2004). It is worth recalling that in the report on the rule of law adopted by 
Nevertheless, the application of the rule of law in the EU and U.S. external action differs due to the different priorities established in their security strategies. Specifically, the NSS emphasizes the protection of freedom while the ESS focuses more importance on the rule of law. The emphasis in the NSS is on the "military" aspect while in the ESS it is on the "civilian" aspect. The NSS represents one country, the sole remaining power in the world, while the ESS represents the compromises proper to an entity of 27 Member States. The NSS reflects the enduring shock of the terrorist attack of 9/11 while the ESS was shaped by the debate on the U.S. invasion of Iraq. The NSS has traditionally seen terrorism by "rogue states" as the primary threat (although President Obama has added other threats), while the ESS has traditionally seen a panoply of threats (terrorism, proliferation, regional conflicts, state failure, ${ }^{561}$ and organized crime). The NSS strategic goal is to make the world "not just safer but better," 562 by "fighting terrorists and tyrants," by building "good relations among the great powers" and by encouraging "free and open societies on every continent." ${ }^{\prime 53}$ Although the Obama NSS avoids any hint of

the conference sponsored by the United States Army Peacekeeping Stability Operations Institute, 6-9 July 2004 , it is recognized that "today, the United States role is changing from that of the dominant military power in the world to that to the biggest exporter of security in the world." As the United States "becomes more involved in peace keeping and stability operations," the report underlines that in "the pursuit of its new global responsibility," it is necessary for its leaders, "both military and civilian," to have "an understanding of the issues relating to the rule of law." $I d$. The report includes the following definitions of rule of law: "the rule of law in the context of peace operations incorporates international and municipal legal obligations and standards applicable to all parties involved in the peace process. As a principle it includes the application of the charter of the United States, international humanitarian law, human rights law, military law, criminal law and procedure, and constitutional law. It also incorporates principles that govern civil and criminal accountability for management and conduct of peace operations (peace keepers). It also allows for follow-up mechanisms to ensure that complaints made against peace keepers are investigated, and were necessary, appropriate enforcement action is taken. The rule of law includes standards by which national institutions of the host country may be held accountable for the failure to comply with universal legal principles and rules. The rule of law is also the framework that governs the relationship between intervening forces and the local community; and the basis upon which the local population may be held accountable for their actions prior to, and following, the intervention." $I d$. at 2.

561. Torsten Gersdorf, Comparison of the Security Strategies of the United States and THE EUROPEAN UNION: Is THERE A COMMON APPROACH IN COMBATING TERrorism? 15 (2005), available $a t$ http://www.dtic.mil/cgi-bin/GetTRDoc?Location=U2\&doc=GetTRDoc.pdf\&AD=ADA437450. The EU concept of "failed states" is different from the U.S. concept of "rogue states" or the George W. Bush "axis of evil." The EU recognizes that failed or failing states are a major source of instability, but it advocates the extension of the rule of law and better governance rather than regime change. The NSS argues that failing states threaten America's security, but does not outline how to keep those states from failing and how to rescue those that have.

562. White House, supra note 559, at 1, available at http://www.globalsecurity.org/military/library/ policy/national/nss-020920.pdf.

563. Id. at introductory remarks by Pres. George W. Bush. 
imposing elections at gun point, the ESS strategic objectives are addressing threats, creating an international legal order based on effective multilateralism, and building a secure neighborhood. With regard to the means for achieving these goals, the Bush NSS proclaimed that the United States will be "using all the elements of national and international power" ${ }^{264}$ and the Obama NSS used the milder expression of "the tough and smart power" taking "international obligations seriously." The ESS emphasizes "effective multilateralism," "preventive engagement with the full spectrum of instruments for crisis management and conflict prevention at their disposal, including political, diplomatic, military and civilian, trade and development activities." This enables the EU to act "before countries around us deteriorate" and to "support the United Nations as it responds to threats to international peace and security;" ${ }^{666}$ while the NSS stresses the significance of hard power and military solutions, based on the option of acting unilaterally if necessary. The conceptual framework of the ESS is "comprehensive security" (global actions, sanctions, the UN's robust engagement including military capabilities as a last resort). ${ }^{567}$

\section{Are the European Union and the United States Allies or Competitors?}

Some years ago, Robert Kagan, the influential American thinker, suggested that, since the collapse of the Soviet Union and the establishment of the European Union, Europe has emerged into a political paradise in the image of the stable, civilized, world order of perpetual peace envisioned by Kant. ${ }^{568}$ In contrast, America, with its massive defense budget, its capacity to launch military operations anywhere in the world, and its willingness to engage in unilateral actions against "rogue states" remains within a violent, anarchic, Hobbesian world. ${ }^{569}$ According to Kagan, in the post-cold war era, this divergent situation has provoked a profound division in the "transatlantic alliance" between the United States and the EU so that "on major strategic and

564. Id. at 6 .

565. Council of the European Union, supra note 443, at 9.

566. Id. at 11 .

567. Kari Möttölä, The Security Strategies of the European Union and the United States as Global Actors: Shifts and Connections in Culture, Function and Power (March 1-5, 2005) (unpublished manuscript) (paper prepared for the ISA Annual Convention, Honolulu, HI).

568. Robert Kagan, Of Paradise and Power: America and Europe in the New World Order (2003).

569. $I d$. 
international questions today" Americans are from Mars (the brave god of war) and Europeans are from Venus (the beautiful goddess of love) ${ }^{570}$ Does this suggestion stand today? Is it correct to conclude that the EU and the United States are bound to become continuing competitors, with Europe encouraging a peaceful world order built upon international law, multilateral common institutions, and shared dispute settlement mechanisms, while the United States continues to maintain its status as a "self-appointed global sheriff" with a powerful military capability willing to engage in combat around the world? Or is this an over-simplification of a much more complex reality ${ }^{571}$

It could perfectly be argued that this disinclination by the EU to use military power as a source of "regime change" is not necessarily a sign of weakness or a sign of an excessively idealistic or Kantian conception of human nature. Rather, it can also reflect the judicious, prudent use of power in response to available evidence, the likelihood of particular threats, and the anticipation of particular outcomes. Analysts like Kagan do not appear to give sufficient weight to the possibility that the combination of legal, diplomatic, and economic alternatives to military engagement might not only be more legitimate, but also more effective than the exercise of military power. The Obama Administration's emphasis on the promotion of the rule of law and the extension of peace in the world, has raised tremendous hope in Europe. However, this emphasis is not a new phenomenon in the foreign policy of the United States On the contrary, it forms part of the perennial "American grand strategy," 572 and of a concept of a "Democratic Peace," also based on Kant's idea of a federal contract between states that would abolish war and would lead to perpetual peace, ${ }^{573}$ that has informed American history for centuries. This American "democratic peace strategy" assumes that democratic states do not go to war against each other but might be aggressive towards nondemocratic states (which form an impoverished "zone of war") for the purpose of bringing them to the democratic, prosperous, and peaceful "zone of peace." ${ }^{574}$ According to this strategy, the objective of democratic peace can

\section{Id}

571. Mary Elise Sarotte, Transatlantic Tensions and European Security (Inst. of European Studies, Univ. of California, Berkeley, Working Paper No. 060505, 2006).

572. G. John Ikenberry, America's Liberal Grand Strategy: Democracy and National Security in the Post-War Era, in American Democracy Promotion: Impulses, Strategies, and Impacts 103, 103-04 (Michael Cox, G. John Ikenberry \& Takashi Inoguchi eds., 2000).

573. Immanuel Kant, Perpetual Peace (Bobbs-Merrill Co., Inc. 1957) (1795).

574. Martin Konstantin Köhring, Beyond Venus and Mars: Comparing Transatlantic Approaches to Democracy Promotion 6-7 (E.U. Diplomacy Papers, Working Paper No. 5/2007, 2007). 
only be achieved by the spread of (liberal) democratic institutions such as multi-party democracy, market economies, free trade, and respect for human rights, which constitute the "best prescription for international peace." Indeed, elements of such a strategy, particularly the promotion of democracy, have regularly underpinned American foreign policy and can be found in the Monroe Doctrine of 1823, in the promotion of democracy in Central and Latin America, the Pax Americana of President Wilson of 1913 under the slogan "making the world safe for democracy," the Reagan/Kirkpatrick doctrine of 1979 that distinguished between "right-wing" and "left-wing" dictatorships for the purpose of democratization, the call by President Carter for "democracy in all nations, not just non-communist autocracies," the Clinton policy of "democratic enlargement" linking political and economic liberalism (free market economy) as a means of advancing the economic interest of the United States, and the Bush doctrine of "pre-emptive attacks and regime change" in order to obtain a free world with free people in the free market economy. This American grand strategy has gained conceptual reinforcement through the propositions of Fukuyama on the "end of history," according to which the advent of democracy in the Western style constitutes the final stage in the political evolution of mankind and has become the final form of human government. ${ }^{576}$ It has also found support in the observations of Huntington regarding a "third wave of democratization" relating to the democratic transitions of developing countries. ${ }^{577}$ These theoretical contributions still influence American policy. The only element that changes in this American grand strategy is the degree of emphasis on the use of force.

In Europe, this American "grand liberal tradition" of promotion of democracy in the world does not exist as a strategy. In the past, the link between democracy and peace did not acquire a practical dimension in foreign policy in Europe. This link remained exclusively in the sphere of ideas, in the writings on freedom and democracy of Kant, Grotius, Locke, Montesquieu, and Rousseau, while in practice, Europeans spread colonialism and authoritarianism in the world. Thus, Europe is only "a debutante" in the instrumentalization of the promotion of democracy and the rule of law as an instrument of its foreign policy. It is important to note, however, that the present European conception is not only based on Kant but also on Grotius,

575. Id. (quoting Michael Edward Brown, Sean M. Lynn-Jones \& Steven E. Miller, Debating the Democratic Peace xiii (1996)).

576. Francis Fukuyama, The End of History and the Last Man (1992).

577. Samuel P. Huntington, The Third Wave: Democratization in the Late Twentieth Century (1991). 
whose Law of War and Peace (1625) constitutes the foundation of the European conception of international law. Consequently, European foreign policy strategy emphasizes respect for the rule of law, the incorporation and promotion of the rule of law as part of international law, and preservation of such international legal order more than the establishment of democracy and freedom in third countries. In the European context, the promotion of democracy is always linked with the establishment of the rule of law and the protection of human rights. Recently, a European link between the rule of law, democracy, and peace was found in the EU notion of "structural stability," which includes an assessment of the root causes of conflict and incorporates the rule of law, sustainable development, human rights, viable political structures, healthy environmental and social conditions, and the capacity to manage a change to democracy without resorting to conflict. This is what is meant by the European concept of "preventive engagement."

Is it possible to bridge this conceptual gap between the EU and the United States? The overtures made by the Obama Administration promise increased cooperation between the United States and the EU. There are no conceptual difficulties with this cooperation from a legal point of view because, as we have seen, there is no legal difference between European and American laws with respect to the meaning of the rule of law. What needs to be improved is the mutual understanding of how the rule of law is promoted. The United States would appear to emphasize "the bottom-up phenomenon," the belief that a free, healthy, and vibrant civil society will always overthrow dictators and opt for a democratic government which will reduce the intervention of the state to the permissible limits imposed by a market economy. By contrast, the EU prefers institutionalized rule of law mechanisms in addition to freedom. This preference is the result of Europe's historical experience of conflict and war, and it has led the EU to concentrate on the state rather than on its society. The EU has a "top-down appreciation" where the emphasis is not placed on civil groups, political parties, and elections but on building up the necessary legal capacity for the state in order to enable it to ensure order through the rule of law and to establish an enduring democracy. ${ }^{578}$

In my view, if the EU and the U.S. Strategies on the promotion of the rule of law and democracy in the world are to succeed, it will require elements of both the U.S. "bottom-up emphasis" on civil society and the EU "top-down appreciation" on the role of the state. Without the U.S. enthusiasm and (2006).

578. Jeffrey Kopstein, The Transatlantic Divide over Democracy Promotion, 29 WASH. Q. 85, 93 
optimism, the promotion of democracy will not become more than a timid attempt, yet without the European attention to the rule of law and institutionbuilding, the triumph of democracy will only be a short-lived parenthesis. Therefore, EU and U.S. strategies on the rule of law need not become a source of transatlantic tension if both sides are willing to draw on the strength and experiences of each other. On the European side, a point of departure may be found in the suggestions of Robert Cooper for a "new liberal imperialism" 579 strategy which would distinguish between a post-modern "zone of peace" which includes Europe and a pre-modern "zone of chaos" (of failed states), and which would incite Europe to become also a military power in order to make achievable the objective of bringing the "efficient and well-governed export of stability and liberty" to the "zone of chaos." ${ }^{580}$ An additional step would draw from the practical assessment of how the United States and the EU use political dialogue, diplomatic measures, multilateral initiatives, economic and financial incentives, conditionalities and sanctions, aid programs, and military intervention. This assessment could be conducive to opening doors and ways of cooperation. I would like to comment briefly on this practice.

With regard to political dialogue the case of Russia provides an illustration. The EU political dialogue with Russia is based on a partnership which includes the rule of law, respect for democracy, human rights, and the market economy and takes place twice a year. The political dialogue of the United States with Russia has been disappointing due to the high expectations created by the United States' strong rhetoric and the emphasis put on a particular person ("the great leader approach"), in contrast to the European preference for structures and institutions. Although the U.S. and EU efforts to coordinate political dialogues with third countries have intensified in recent years following the 2007 U.S.-EU summit declaration (e.g., in central Asia), this effort has not completely succeeded due to an alleged U.S. benevolence with regard to regimes that cooperate on counter-terrorism (e.g., Pakistan, Belarus).

With regard to multilateral initiatives where the EU and the United States have collaborated successfully on establishing priorities for the UN Human Rights Council, they have also co-sponsored resolutions adopted by the UN 3rd Committee on Belarus, Burma, Iran, and North Korea; they have worked

579. Robert Cooper, The Breaking of Nations: Order and Chaos in the Twenty-first Century (2003)

580. Robert Cooper, The Post-Modern State, in Re-Ordering THE World 11, 17 (Mark Leonard ed., 2002). See generally, Robert Cooper, The Post-Modern State And the World Order (2000). 
together in the Peace-Building Commission; they have together managed to establish the UN Democracy Fund that provides grants to pro-democracy civil organizations in the world; they have caused the G-8 to adopt the "Broader Middle-East and North Africa Initiative" (MENA), which is aimed at fostering economic and political liberalization in Arab and non-Arab Muslim countries. $^{581}$ Also, at present, EU and U.S. cooperation on multilateral initiatives is increasing.

With regard to incentives, conditionalities, and sanctions, the United States is seen as more capable of providing quick responses to disruptions in countries pursuing democratic transitions. However, this is at the risk of sometimes being perceived as taking unilateral action. ${ }^{582}$ The EU, on the other hand is slower, pursuing a long-term strategy based on persuasion and consent as well as the encouragement of multilateral responses (UN sanctions). But the EU and the United States have sometimes cooperated on joint measures and sanctions (Belarus).

Without doubt the most controversial question is the place that the use of force occupies in the EU and U.S. strategies. In the view of the EU, neither democracy nor the rule of law can be imposed. They have to be built from within, with a preference for civilian coercive measures over military involvement, the latter only allowed in "pre-crisis" situations, as part of a comprehensive conflict prevention strategy ${ }^{583}$ By contrast, the United States of the past Bush Administration has been perceived as using the promotion of the rule of law and democracy "as a repackaged commitment to the unilateral use of force as well as a justification for war," breakdown in the solidarity required for transatlantic cooperation."

Aid programs purport to "foster a democratic opening in a nondemocratic country or to further a democratic transition in a country that has experienced a democratic opening." 586 The EU has been using an impressive panoply of instruments in this regard (European Neighbourhood and Partnership Instrument, pre-accession instruments, stability instruments, human rights instruments in the form of TACIS, PHARE, SAP, CARDS, and

581. Köhring, supra note 574, at 14-23. Haizam Amirah-Fernandez \& Irene Menendez, Reform in Comparative Perspective, U.S. and E.U. strategies for democracy promotion in MENA región after 9/11, 17 J. Contemp. Eur. Stud. 325 (2009).

582. Helms-Burton Act, 22 U.S.C. $\S$ 6021-6091 (1996).

583. GERSDORF, supra note 561.

584. Kopstein, supra note 578 , at 85.

585. Laurence Whitehead, Europe, Transatlantic Co-operation, and Democratization, Promoting Democracy and the Rule of Law: EU and US Strategies and Instruments 3 (2004).

586. Thomas Carothers, Aiding Democracy Abroad: The Learning Curve 6 (1999). 
MEDA programs). It has been suggested that the EU concentrates on local ownership while the United States often supports "high-profile initiatives" that are sometimes "insensitive to local conditions" and that use "replica features of American democracy." ${ }^{587}$ However, the recently adopted U.S. Guiding Principles for Stabilization and Reconstruction offer ample space for cooperation between the United States and the EU. ${ }^{588}$ Finally, both the EU and the United States have set up mechanisms to coordinate their respective aid programs - Europe Aid Cooperation Office in the case of the EU, USAID in the case of the United States - and there is a promising possibility of coordination in electoral assistance even though the EU has so far preferred to carry out its electoral assistance missions independently. Both the United States, the EU, and its Member States have a varied number of NGOs active in "first-in" fundings for the promotion of the rule of law and democracy in the world. Although the U.S. national endowment for democracy, the U.S. World Movement for Democracy, several German foundations (Heinrich-Böll Stiftung, Konrad-Adenauer Stiftung, etc.) and the British Westminster Foundations belong to different political persuasions, there is also ample room for a more fruitful cooperation with each other.

Finally, the ratification of the Lisbon Treaty has created new EU institutions, such as the European Council with its permanent President, ${ }^{589}$ a reinforced High Representative/Chair of the Foreign Affairs Council of the EU, and the European External Action Service (EEAS). All of these institutions can be conducive to greater European cooperation in improved U.S.-EU discussions. These innovations may also facilitate more direct links with the United States. In particular, the EEAS may also allow for greater EUU.S. cooperation on assessments of emerging conflicts and the development of joint strategies. With the opportunity afforded by the fifteenth anniversary of the New Transatlantic Agenda in mid-2010, the EU and United States ought to shape a new cooperative agenda with a primary focus on conflict prevention, democracy and the rule of law which would allow their respective capacities for "comprehensive" stabilization and reconstruction missions to become interoperable and mutually supportive in our globalized world.

587. Köhring, supra note 574. Richard Youngs, Democracy Promotion: The Case of European Union Strategy 49 (Centre for European Policy Studies, Working Paper No. 167, 2001).

588. United States Institute of Peace, Guiding Principles for Stabilization and RECONSTRUCTION (2009), available at http://www.usip.org/files/resources/guiding_principles_full.pdf.

589. Herman van Rompuy, The Challenges for Europe in a Changing World 1-16 (E.U. Diplomacy Papers, Working Paper No. 3/2010, 2010). 


\section{Epilogue: A Universal Definition of the Rule of Law?}

The rule of law distinguishes European and American civilizations from those of other cultures. In the European and American historical experience, the rule of law has divorced social conflicts from force, emotions, interests, and prejudices which, contrary to accusations made herein, have more frequently produced liberating rather than repressive results. Do the traits of the European and American rule of law outlined in these pages have a chance of becoming part of a future planetary legal culture? It is encouraging to note that the international community and, in particular, most non-Western nations, have in fact opted in favor of human rights conventions and in particular of the Universal Declaration of Human Rights (1948) whose Preamble Paragraph 3 (it is worth repeating) states that "it is essential, if man is not to be compelled to have recourse as a last resort, to rebellion against tyranny and oppression, that human rights should be protected by the rule of law." Thereby, the international community has opted for the basic inventory of individual and social rights, of human dignity, personal freedom, protection against arbitrariness, active political rights, freedom of voting, equality before the law, and the responsibility of society for the social and economic conditions of its members. As we have seen, the realization of these postulates cannot succeed unless these rights are safeguarded by means of predictable legality and procedures enforced by independent courts. There are good reasons for hoping that the fundamental decision of these nations is more than lip service before international organizations by whatever politicians happen to be in power.

This implies that any universal definition of the rule of law will have to incorporate at least the following four principles: (i) the principle that power may not be exercised arbitrarily, (this principle implies a rejection of the rule by man and requires that laws should be prospective, accessible and clear); (ii) the principle of supremacy of the law, which distinguishes the rule of law from the rule by law and requires acceptance of the principle of separation of powers, and means that the law applies to all including the sovereign and that the law is applied to specific cases by independent judicial institutions; (iii) the principle that law must apply to all persons equally without discrimination (this requires that the law should be of general application and capable of being obeyed); and (iv) the principle of respect for universal human rights as laid down in those international instruments and conventions accepted by the international community. 